Nova Southeastern University

Florida

NSUWorks

NOVA SOUTHEASTERN

UNIVERSITY

\title{
Confidence in Law Enforcement When African-Americans are Underrepresented on the Force: An Exploratory Study
}

Charles E. MacLean

Nova Southeastern University, chuckmaclean@yahoo.com

Follow this and additional works at: https://nsuworks.nova.edu/fse_etd

Part of the Education Commons

\section{Share Feedback About This Item}

\section{NSUWorks Citation}

Charles E. MacLean. 2019. Confidence in Law Enforcement When African-Americans are Underrepresented on the Force: An Exploratory Study. Doctoral dissertation. Nova Southeastern University. Retrieved from NSUWorks, Abraham S. Fischler College of Education. (246) https://nsuworks.nova.edu/fse_etd/246.

This Dissertation is brought to you by the Abraham S. Fischler College of Education at NSUWorks. It has been accepted for inclusion in Theses and Dissertations by an authorized administrator of NSUWorks. For more information, please contact nsuworks@nova.edu. 
Running Head: CONFIDENCE IN LAW ENFORCEMENT

\title{
Nova Southeastern University \\ Abraham S. Fischler College of Education \\ School of Criminal Justice
}

Confidence in Law Enforcement When African-Americans are Underrepresented on the Force: An Exploratory Study

\author{
by \\ Charles E. MacLean \\ A Dissertation Presented to the \\ Abraham S. Fischler College of Education - School of Criminal Justice \\ of Nova Southeastern University \\ in Partial Fulfillment of the Requirements for the Degree of \\ Doctor of Philosophy
}

Nova Southeastern University

2019 
CONFIDENCE IN LAW ENFORCEMENT

(C) Charles E. MacLean, 2019 


\title{
CONFIDENCE IN LAW ENFORCEMENT
}

\author{
Approval Page
}

This dissertation was submitted by Charles MacLean, under the direction of the persons listed below. It was submitted to the School of Crixrinal Justice, Abraham S. Fischler Colloge of Education, and approved in partial fulfillonent of the requirements for the degree of Doctor of Philosophy at Nova Southeastern University.
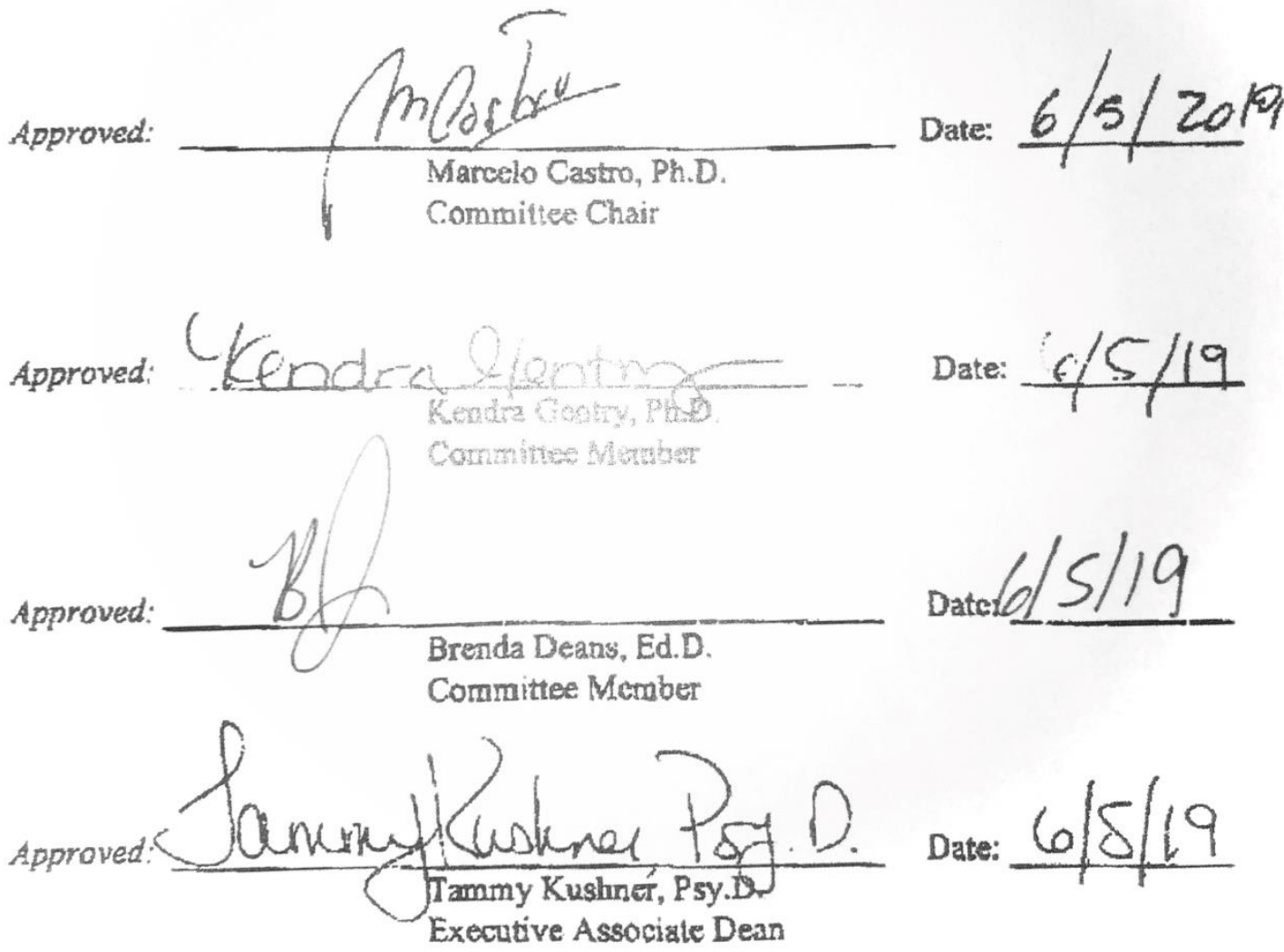


\section{CONFIDENCE IN LAW ENFORCEMENT}

\section{Acknowledgments}

I dedicate this dissertation to Marie, my wife and co-pilot.

I am grateful for the tireless effort of my dissertation committee, especially Committee Chair Dr. Marcelo Castro, whose steady hands guided my unsteady ones through the rough seas of the research, analysis, and writing processes. 


\title{
CONFIDENCE IN LAW ENFORCEMENT
}

\begin{abstract}
Confidence in Law Enforcement When African-Americans are Underrepresented on the Force: An Exploratory Study, Charles E. MacLean, 2019: Dissertation, Nova Southeastern University, Abraham S. Fischler College of Education and School of Criminal Justice.

Descriptors: Law Enforcement, Racial Mirror Index, Civilian Confidence, Civilian Trust, Civilian Satisfaction, Minority Underrepresentation.

This dissertation explores the prediction that when African-Americans are underrepresented among sworn officers in a community's local law enforcement agencies compared to the African-American proportions in that community's overall population, African-American civilians' confidence in their local law enforcement agencies may suffer, leading to impaired respect for law, reduced civilian cooperation with law enforcement, and civilian impressions of weakened procedural justice and fairness. With low civilian confidence, the argument goes, one could expect an enhanced sense of disenfranchisement among the underrepresented sub-populations.
\end{abstract}

The purpose of this study is to consider the impact of underrepresentation of AfricanAmericans among sworn officers serving a local community, explore the key correlates of civilian confidence viewed through the lens of African-American perceptions and attitudes, and confront the superordinate roles that procedural justice and police effectiveness play in forming African-American civilian attitudes of confidence, trust, and satisfaction in local law enforcement.

To quantify representativeness, this study expresses relative racial compositions of the police and the policed as a Racial Mirror Index ("RMI"). If the percent of a community's police, who are African-American, exactly matches the percent of the policed in that community, who are African-American, the RMI-AA ("Racial Mirror Index-AfricanAmerican") would equal 100. RMI-AAs over 100 indicate African-Americans are overrepresented on the local law enforcement agency compared to the African-American share of the general population; RMI-AAs under 100 indicate African-Americans are underrepresented among sworn officers on the force.

Despite expectations, as this study makes clear, RMI-AA is not a significant predictor of African-American civilian confidence, trust, and satisfaction in local law enforcement. Instead, African-American attitudes about local law enforcement are overwhelmingly driven by African-American perceptions of procedural justice and police effectiveness. African-American confidence, trust, and satisfaction in law enforcement remains far lower than for Whites regardless of RMI-AA and the degree of underrepresentation on the force. Thus, law enforcement agencies cannot hire their way out of this confidence gap through minority recruitment. Instead, improving African-American confidence in local law enforcement will require the agencies to engage with the far more substantive work of ensuring their officers deliver both procedural justice and effective policing. 


\section{Table of Contents}

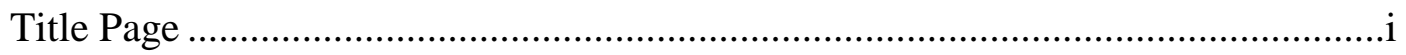

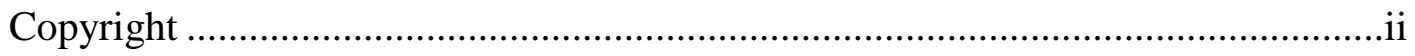

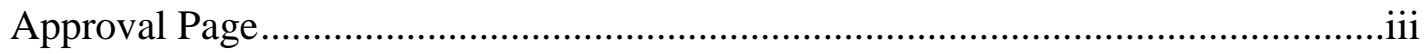

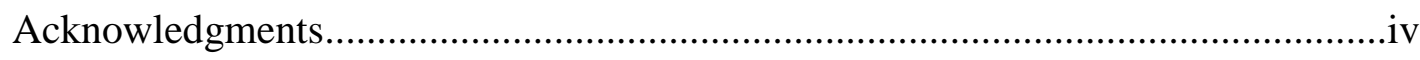

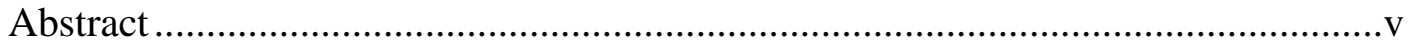

Table of Contents .......................................................................................... vi

Chapter 1: Introduction .............................................................................

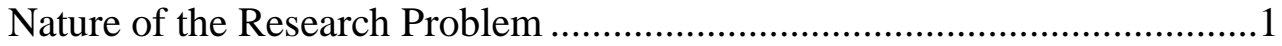

Purpose of the Study ..........................................................................

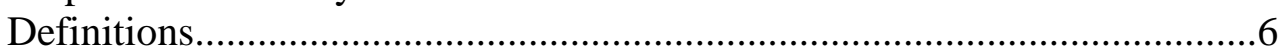

Chapter 2: Literature Review ................................................................... 8

Offender/Suspect Racial and Ethnic Characteristics .................................10

Police Officer Racial and Ethnic Characteristics ........................................11

Police Agencies Mirroring the Racial Composition of the Served

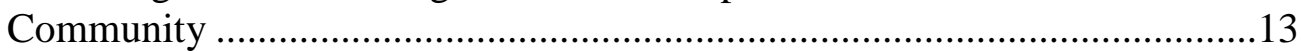

Public Distrust - Especially Minority Distrust - in Law Enforcement .........14

The Impact of the Racial Mirror Index on Excessive Force Complaints ......24

Measuring Civilian Confidence in Local Law Enforcement ........................27

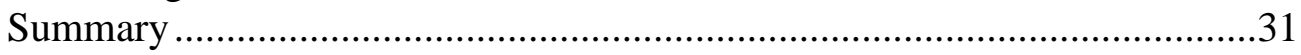

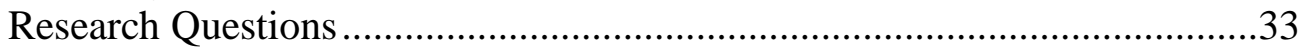

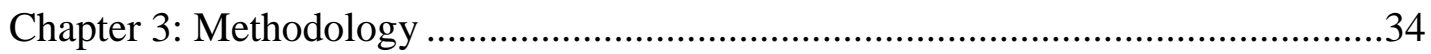

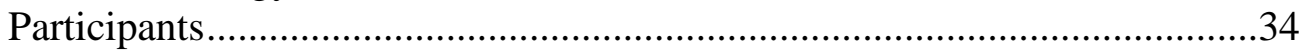

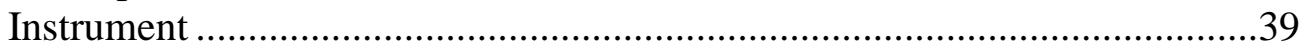

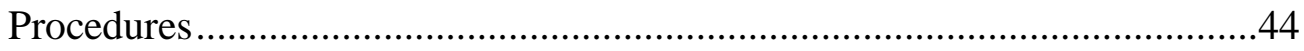

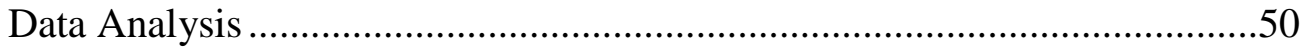

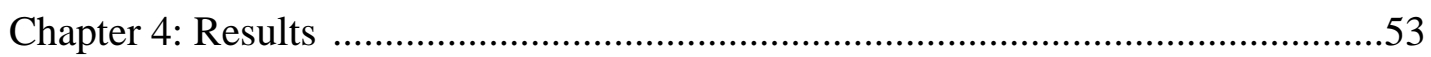

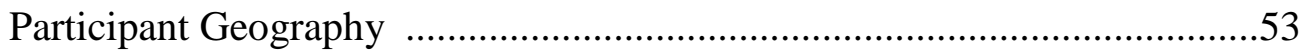

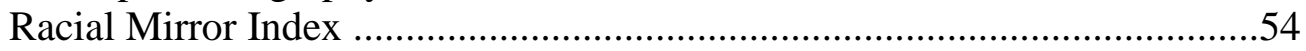

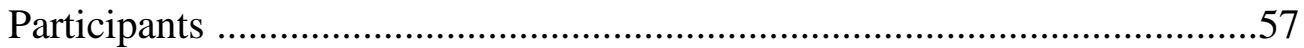

Exploratory Factor Analysis ............................................................58

Confirmatory Factor Analysis and Reliability Estimation .........................64

Associational Analyses - Dependent and Independent Variables ...............65

Ordinal Logistic Regression ................................................................ 74 
CONFIDENCE IN LAW ENFORCEMENT

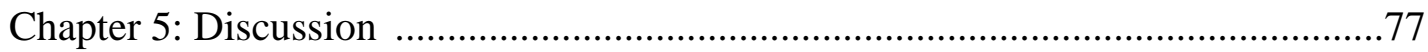

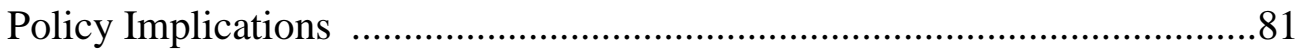

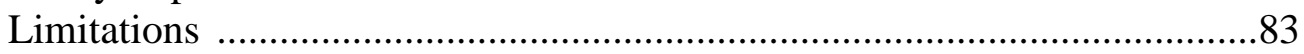

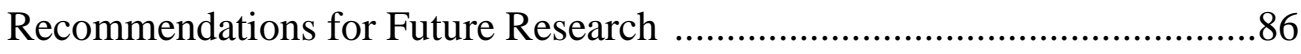

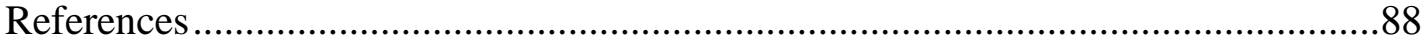

Appendix

Attitudes About Law Enforcement in Your Community Survey .................118

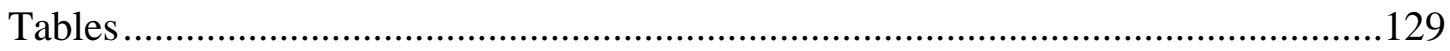

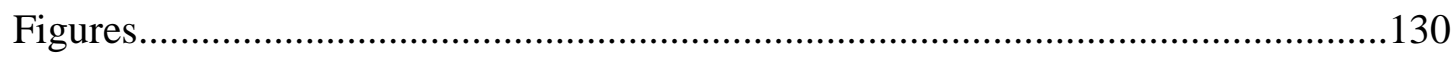




\section{Running Head: CONFIDENCE IN LAW ENFORCEMENT}

\section{Chapter 1}

\section{Introduction}

\section{Nature of the Research Problem}

This research study begins to answer the question: Is the level of AfricanAmerican civilians' confidence in their local law enforcement agencies adversely affected when African-Americans are underrepresented among sworn officers in a community's local law enforcement agencies compared to the African-American proportion in that community's overall population?

Where civilian confidence is suppressed, civilian cooperation with law enforcement is diminished as are civilian impressions of procedural justice and fairness (Murphy \& Cherney, 2012; Murphy, Cramer, Waymire, \& Barkworth, 2018; Tyler, Goff, \& MacCoun, 2015, pp. 81-82; Tyler, 2004, pp. 86-87; Tyler \& Huo, 2002, Tyler \& Jackson, 2014, pp. 79-80, 83, 85-87, 89). With low civilian confidence, one could expect greater frequency of excessive use of force complaints (Terrill \& Paoline, 2015, pp. 193194) and enhanced likelihood of a feeling of disenfranchisement among the underserved or underrepresented sub-populations (Jackson, et al., 2012, p. 1053).

The purpose of this study is to consider the African-American civilian confidence impact when African-Americans are underrepresented among sworn officers serving a local community. To explore the impact of African-American underrepresentation on the local force on African-American civilian confidence in local law enforcement, the researcher examined the key correlates of civilian confidence. Finally, next steps are identified such as the benefits of diversity and representative bureaucracies in law enforcement, and the critical need to focus on procedural justice and police effectiveness 


\section{CONFIDENCE IN LAW ENFORCEMENT}

to improve African-American confidence, trust, and satisfaction in local law enforcement.

Kennedy, et al. (2017), computed a “disproportionality index" by metropolitan area that treated racial overrepresentation and underrepresentation on a city's police force as equivalent but also assessed disproportionality by racial group by city (pp. 41-42, 4648). That disproportionality index thus treated overrepresentation and underrepresentation as equivalent without distinguishing the direction; that is, without differentiating between overrepresentation and underrepresentation. This study, instead, expresses relative racial compositions of the police and the policed as a Racial Mirror Index-African American ("RMI-AA"); that is, if the percent of a community's sworn police officers, who are African-American, exactly matches the percent of the policed in that community, who are African-American, the RMI-AA (Racial Mirror Index-AfricanAmerican) would equal 100. Thus, an RMI-AA greater than 100 would indicate AfricanAmericans were overrepresented among sworn officers in the local law enforcement agency relative to the served population as a whole and an RMI-AA less than 100 would indicate African-Americans were underrepresented. Implicit behind the RMI-AA concept and this study is the intuitive suggestion that RMI-AA may serve as a proxy for minority disenfranchisement from a community's local law enforcement such that one might expect minority approval of and confidence in law enforcement to be higher when RMIAA approaches or exceeds 100 and would likewise expect minority approval and confidence to decline the further the RMI-AA falls below 100 .

Of course, RMI-AA as an assessment tool is an inexact measure and fails to account for other variables that may impact excessive force complaints and public 


\section{CONFIDENCE IN LAW ENFORCEMENT}

satisfaction with law enforcement. For example, all else equal, a law enforcement agency effectively using community policing techniques may be expected to have overall higher African-American civilian satisfaction rates and lower excessive force complaint rates almost without regard to RMI-AA; however, empirical research has found that since many agencies, driven by readily available community policing funding, label their efforts as "community policing" without using all community policing devices and thus fail to show statistically reduced use of force incidents and complaints (Shjarback \& White, 2016, p. 51). Similarly, a law enforcement agency that steadfastly applies a due process model would be expected to yield enhanced civilian perceptions of procedural justice and legitimacy leading to improved public satisfaction in local law enforcement independent of RMI (Murphy, 2017; Sargent, 2017, pp. 928-929, 935). And of course, a local law enforcement agency with a history of excessive force incidents or strained police-minority relations or with a very recent and serious incident of excessive law enforcement force directed toward one member of a visible minority or an entire minority group, especially where it appears the police oversight or investigation is deemed insufficient or biased, may be expected to have a lower overall minority civilian confidence in local law enforcement than those population groups proportionately represented on the force (Morton, 2018; Weitzer, 2002).

Nonetheless, to the extent RMI-AA > 100 is strongly correlated with higher African-American civilian satisfaction, important criminal justice leadership lessons may be gleaned from RMI-AA. Certainly, at a minimum, if those correlations are strongly positive, an agency may choose to pursue a recruitment scheme designed to attract a mix of new recruits to help the agency evolve its racial composition to a point far more 


\section{CONFIDENCE IN LAW ENFORCEMENT}

reflective of the racial composition of the policed (Wilson, Wilson, \& Gwann, 2016). If there is no such correlation, then minority officer recruitment initiatives in other agencies should be reassessed although other benefits of diversity and minority representativeness on the local police force may still support increased minority officer recruitment and retention efforts.

After African-American underrepresentation among local law enforcement was quantified using the RMI-AA, the study then quantified African-American civilian confidence in their local law enforcement officers and agencies. This research adopted a quantitative design. RMI-AA and African-American civilian confidence were assessed based on data mining of governmental reports to determine RMI-AA by American city coupled with an online survey intended to address African-American civilian confidence in local law enforcement across America.

In the final analysis, public confidence or distrust toward local law enforcement is affected by the public's perception of the degree to which law enforcement is grounded in ethics, fairness, and due process versus the public's perception of the degree to which law enforcement is grounded in violence, efficiency, expedience, and ends - not means, a concept often summarized as "procedural justice" (Mazerolle, Antrobus, Bennett, \& Tyler, 2013; Mazerolle, Bennett, Davis, Sargeant, \& Manning, 2013, pp. 247-248, 257; Murphy, Mazerolle, \& Bennett, 2014; Sun, Wu, Van Craen, \& Hsu 2018; Taylor \& Lawton, 2012, p. 415; Tyler, 2004). Democratic policing, in the ideal, is policing that represents, supports, protects, and empathizes with the policed (Lemieux, 2014; Manning, 2016, pp. 4-38; Pino \& Wiatrowski, 2016, p. 9). According to democratic policing theory, when the policed feel persecuted and not protected, or feel excluded and 


\section{CONFIDENCE IN LAW ENFORCEMENT}

not included, then policing is not viewed by the policed as democratic at all, because "in democratic societies the primary mission of the police is to protect citizens against crime and disorder, including illegal or corrupt behavior by officials. In democracies, police have carefully circumscribed roles that require close and positive relations with ordinary citizens" (Wiatrowski \& Goldstone, 2010, pp. 80-81). There may be a strong correlation between the similarity or dissimilarity of racial compositions of the police versus the policed on the one hand and the degree of animosity or dissatisfaction of the policed toward the police on the other hand. Of course, there may be many steps a law enforcement agency could take or tools an agency could use, despite racial disparities, to mitigate any potential or resulting animosity. Indeed, community policing is a tool often cited as helping the police see themselves as the protectors of due process and helping the policed see themselves as represented and protected by the agency and its officers (Fisher-Stewart, 2007; Lemieux, 2014; O’Shea, 2000; Ray, 2012). Some legal scholars have challenged the alleged existence of this democratic policing paradigm in America, holding instead that the insular nature of American policing renders it mostly unanswerable to democratic norms and immune from effective public oversight (Friedman \& Ponomarenko, 2015, p. 1907). This study explores some of those correlations.

\section{Purpose of the Study}

African-American civilian confidence in law enforcement falls substantially short of White civilian confidence in law enforcement. That confidence "race gap" has been found to suppress African-American trust in and cooperation with local police. The purpose of this study was to quantify African-American underrepresentation in American 


\section{CONFIDENCE IN LAW ENFORCEMENT}

law enforcement agencies, but beyond that, the study was designed to assess the degree to which that underrepresentation adversely affects African-American civilian confidence in local law enforcement agencies independent of the confidence-reducing impacts known to arise from fear of crime, neighborhood context, and recent negative contacts with law enforcement. Although the study found the independent impact of African-American underrepresentation on local police forces was not significant, this study nonetheless recommends that law enforcement agencies continue to pursue managerial strategies to increase African-American police officer hiring and retention and thereby seek to capitalize on the other benefits of diversity and representativeness.

\section{Definitions}

Civilian confidence: was measured based on civilian responses to the survey and is intended to measure a conglomerated sense of civilian trust, satisfaction, and confidence.

Racial categories (for population characteristics): are defined by the United States Census Bureau.

Racial categories (for sworn officer characteristics): are defined within the Law Enforcement Management and Administrative Statistics ("LEMAS") database and survey.

Racial Mirror Index (“RMI”): a measure of the degree to which the racial composition of the sworn officers in a community mirror the racial composition of the civilians in that community. An RMI of 100 means the racial composition of the police and the policed are identical. An RMI of less than 100 indicates that minorities are underserved among sworn officers serving that community. 


\section{CONFIDENCE IN LAW ENFORCEMENT}

Racial Mirror Index - African-American ("RMI-AA”): a measure of the degree to which African-American civilians are over- or under-represented among sworn officers serving that community. If RMI-AA $=100$, the proportion of African-Americans in the local community is identical to the proportion of African-Americans among sworn officers serving that community.

This study was designed to assess the national situation using a relatively small but nonetheless statistically significant sample recruited using an online survey panel of African-American civilians. This modest approach is necessitated by the paucity of extant, consistent, and reliable city-level measurements of minority confidence in local law enforcement, complicated by the reality that a limited survey budget requires a modest scope. Careful survey design improved the generalizability of the study's findings by drawing respondents from across the United States rather than selecting a few cities and hoping they may prove to be representative of the whole. 


\section{CONFIDENCE IN LAW ENFORCEMENT}

\section{Chapter 2}

\section{Literature Review}

Community perceptions of law enforcement and how those perceptions are affected by the racial and ethnic profile of each community's civilians have been studied at length revealing that civilians of color have, on average, less confidence in local law enforcement than non-minority civilians. These civilian perceptions of law enforcement are notoriously "fuzzy” (Myrstol, 2011, p 27; Worrall, 1999), arising as a complex function of attitudes, experiences, predispositions, media impacts, neighborhood context, fear of crime, life course position, and so on. This study explored the intersection of the racial composition of local law enforcement ("the police") and the racial composition of the community served ("the policed") and the impact of African-American underrepresentation among sworn officers on African-American civilian confidence in local law enforcement and the correlations between those two concepts. This literature review presents the researcher's findings from an exhaustive search of scholarly, practitioner, and popular works exploring related topics. That search yielded over 330 references, including 172 key scholarly articles, 126 other scholarly and government works, and 38 practitioner and popular works. Those articles and works have been sorted into six predominant themes relevant to this study: (1) offender and suspect racial and ethnic characteristics; (2) police officer racial and ethnic characteristics; (3) police agencies mirroring the racial composition of the served community; (4) public distrust especially minority (African-American) distrust - in law enforcement; (5) the impact of the Racial Mirror Index on excessive force; and (6) quantitatively measuring civilian confidence in local law enforcement. 


\section{CONFIDENCE IN LAW ENFORCEMENT}

The kernel for this study approach may be found in the literature related to the representative bureaucracy construct (Kennedy, 2014; Kennedy, Butz, Lajevardi, \& Nanes, 2017), a term and theory coined in 1944 (Kingsley, 1944). That construct posits that bureaucracy is most reliably "representative" of (that is, protectors of) the served population when its bureaucrats are representative of that population in terms of socioeconomic, demographic, and other overt characteristics (Slobogin, 2014, p. 1734). Specifically, the representative bureaucracy construct is helpfully divided into passive representation (the degree to which the demographic and other makeup of the bureaucrats matches those of the served population) and active representation (the degree to which the demographically matching or sincerely representative bureaucrats actively lobby for and adopt procedures that directly and consistently serve the interests of the demographic sub-groups in the community served) (Hong, 2017b; Morabito \& Shelley, 2015, pp. 345346; Schuck \& Rabe-Kemp, 2016). The representative bureaucracy construct "suggests that a bureaucracy that more accurately matches the demographic makeup of its constituents will provide higher quality, more democratic, and more responsive outcomes for members of the community" (Kennedy, et al., 2017, pp. 23-24). Specifically, researchers have found that passive representation can lead to active representation and that both can help equalize power among minority and majority groups (Morabito \& Shelley, 2015, pp. 345-346); improve perceptions of agency legitimacy, accountability, equity, and procedural justice (Bottoms \& Tankebe, 2012; Kennedy, et al., 2017, pp. 2324; Rosenbaum, Lawrence, Hartnett, McDevitt, \& Posick, 2015); reduce frequency of racial profiling (Hong, 2017b); improve perceptions of agency integrity (Hong, 2017a); and increase the likelihood that an agency will promulgate written civilian complaint 


\section{CONFIDENCE IN LAW ENFORCEMENT}

procedures, will create a civilian review board, and will decrease the number of excessive force complaints (Kennedy, et al., 2017). Researcher Sounman Hong has even purported to quantify the magnitude of the benefits wrought by representative bureaucracy in policing, for example: "A 10 percent increase in the share of ethnic minority police officers during the studied period was associated with a 1.4-3.8 percent decrease in the number of crime incidents reported to the average police force" (Hong, 2016, p. 30); and a $1.5 \%$ increase in proportion of officers from ethnic minorities in a given law enforcement agency is associated with a decrease in the number of complaints from ethnic minorities, an $11 \%$ overall decrease in the number of substantiated complaints per officer, and a $20 \%$ decrease in the percent of all complaints that were substantiated (Hong, 2017a, p. 203). In spite of the logic and strength of the representative bureaucracy construct and its adherents, Theobald and Haider-Markel (2009) have argued in the alternative that the benefits of representative bureaucracy flow more from the race of the officer than from the improved representativeness of the agency and thus that increasing the percent of Black officers may reduce the confidence that White civilians would otherwise have exhibited in local law enforcement (p. 421).

\section{Offender/Suspect Racial and Ethnic Characteristics}

The literature is replete with scholarly and lay opinions regarding the degree to which an offender's (or suspect's) perceived or actual race or ethnic characteristics affect the degree of justice, due process, suspicion, and violence received from the police. Garner, Maxwell, and Heraux (2002) did a superlative job gathering the alreadysubstantial literature, extant in 2002, regarding the impact of offender characteristics on use of force. Expanding on that early research base, Hyland, Langton, and Davis (2015) 


\section{CONFIDENCE IN LAW ENFORCEMENT}

found that Blacks were 3.5\% more likely than Whites to experience nonfatal force during a police encounter, and traffic stops involving an officer and driver of different races were $2 \%$ more likely to involve use of force than traffic stops involving an officer and driver of the same race. Tyler and Huo (2002) found that Black civilians are more likely than White counterparts to be treated with excessive police force and are not unsurprisingly more likely to consider police biased against them and bring complaints against the officers who they deem to have treated them unfairly (pp. 141, 151). Stults, Parker, and Lane (2010) explored the quite stark differentials in vehicle stop rates among Black, White, and Hispanic drivers, and noted the spatial concentration of those stops in high-minority (sometimes off-handedly called "high-crime") sections of metropolitan areas. Many commentators (LaFraniere \& Lehren, 2015; Tomaskovic-Devey \& Warren, 2009; Woods, 2015) have re-labeled that racially disparate rate of vehicle stops as “driving while black." Warren (2010) noted that race gaps in civilian trust in the police are driven in part by minority civilian perceptions that agencies engage in racial profiling when effecting traffic stops (p. 1039). Police officers' racial and ethnic characteristics have also been found to play a role in their law enforcement behaviors and the public's reactions to them as discussed in the next section.

\section{Police Officer Racial and Ethnic Characteristics}

A number of studies have quantified the correlation between police officers' race or ethnic characteristics and various behaviors in the course of their law enforcement duties. Shusta, Levine, Wong, Olson, and Harris (2014) assessed the many historical changes in the gender, racial, and ethnic composition of sworn officers in police agencies, including increased proportions of female and minority officers, up from $14.5 \%$ to $22.7 \%$ 


\section{CONFIDENCE IN LAW ENFORCEMENT}

among local police offices and up from $13.4 \%$ to $17.1 \%$ among sheriffs' offices between 1990 and 2000. Bekiempis (2015) brought that study up to date, explaining that the minority proportion of police officers had doubled between 1987 and 2013. Sun and Payne (2004) found that Black officers are much more likely than White officers to use coercion with suspects, but conversely, were much more likely than White officers to engage in supportive behaviors when encountering same-race suspects in predominantly Black neighborhoods. En route to explaining that a very small proportion of all officers commits a very large proportion of excessive force incidents, Brandl and Stroshine (2012), engaging in meta-analysis, found that the correlation between officer race and use of force was inconsistent at best with some studies concluding that Black officers were more likely to use force (Sun \& Payne, 2004) while other studies reached the opposite or a neutral conclusion (Brandl \& Stroshine, 2012, p. 558; Garner, Maxwell, \& Heraux, 2012; Paoline, Gau, \& Terrill, 2018). Race and ethnicity were also found to be strong determinants of (or correlates with) officer-involved shootings (McElvain \& Kposowa, 2008). The more interesting analyses (Bouranta, Siskos, \& Tsotsolas, 2015; Chapman, 2012; Lasley, Larson, Kelso, \& Brown, 2011; Stultz, Parker, \& Lane, 2010) broadened the simple race-behaviors studies and strived to find and quantify the relationship between an officer's race/ethnicity, the officer's affinity toward his or her beat (or community), and the officer's propensity to use appropriate force and be well-respected and well-accepted in the served community. The next section addresses the confluence of police agency racial composition and the racial compositions of the communities each agency serves. 


\section{CONFIDENCE IN LAW ENFORCEMENT}

\section{Police Agencies Mirroring the Racial Composition of the Served Community}

Sometimes questioning whether diverse police forces are fairer or treat their communities more justly (DePillis, 2014; CRS, 2010; Howell, Perry, \& Vile, 2004), and at other times considering racial composition mismatches to be a call to action (Bayley, Davis, \& Davis, 2015; Rahr \& Rice, 2015), scholarly commentators (Bradford, Murphy, \& Jackson, 2014) and the popular press (Ashkenas \& Park, 2015; Bolten, 2015; Dallas Morning News, 2015; Gillum, 2014; Hall, 2016; Milewski, 2014; Morial, 2016) have begun to notice that the racial compositions of police agencies serving many American communities are not equivalent to the racial compositions of the communities the agencies serve. Indeed, in a masterful nationwide look based on the 2013 Law Enforcement Management and Administrative Statistics ("LEMAS”) data (Reaves, 2015), the Governing Journal (Governing, 2015; Governing Data, 2015) prepared a cityby-city assessment of the degree to which the racial and ethnic composition of the sworn law enforcement officers in each of 269 large American cities mirrored the racial composition in each city. The results were fascinating. "Racial and ethnic minorities were underrepresented by a combined 24 percent on average compared to their proportion in the communities served" (Governing, 2015, p. 2). In thirty moderate-to-large metropolitan areas exhibiting the greatest underrepresentation of minorities on the local police force, the minority underrepresentation percentage exceeded $40 \%$ (Governing, 2015, p. 4).

This study uses the Governing 2015 and LEMAS 2013 data as springboards to assess minority underrepresentation and the putative impacts of that minority underrepresentation on civilian confidence in local law enforcement. When a 


\section{CONFIDENCE IN LAW ENFORCEMENT}

community's local law enforcement agency fails to mirror (racially, ethnically, culturally) the community it serves, do the minorities exhibit greater distrust of law enforcement as measured by diminished confidence in local law enforcement?

\section{Public Distrust - Especially Minority Distrust - in Law Enforcement}

Civilian trust or confidence in local law enforcement results from the complex interrelationships between civilians and law enforcement and civilian perceptions of those relationships, illustrated in graphical form as follows (CACP, 2017b):

\section{Figure 1. The Principles of Civilian Trust/Confidence in Local Law Enforcement}

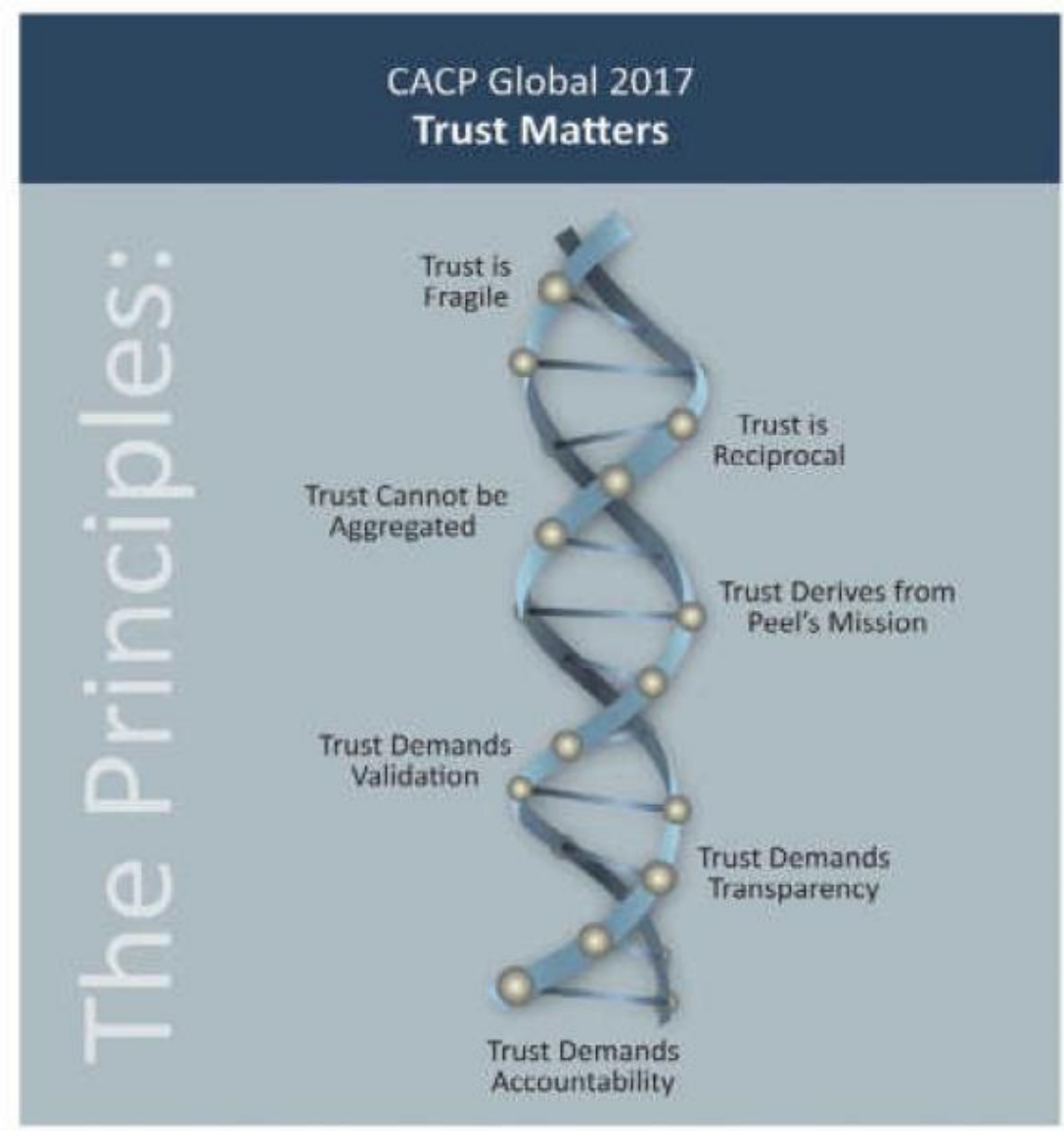

In prose, trust can be fleeting and is fragile. It must be reciprocal and derived from mutual respect and consideration. Trust must be regularly validated to ensure it thrives. Finally, trust without transparency and accountability cannot survive for long. 


\section{CONFIDENCE IN LAW ENFORCEMENT}

Civilian trust, if created, nourished, and safeguarded, can engender many societal benefits, including greater cooperation with law enforcement, greater willingness to adhere to legal requirements, and greater propensity of civilians to experience concomitant positive feelings about the health of their respective communities, illustrated effectively by Jackson and Gau (2016, figure 1, p. 4):

Figure 2. The Benefits of Civilian Trust/Confidence in Local Law Enforcement

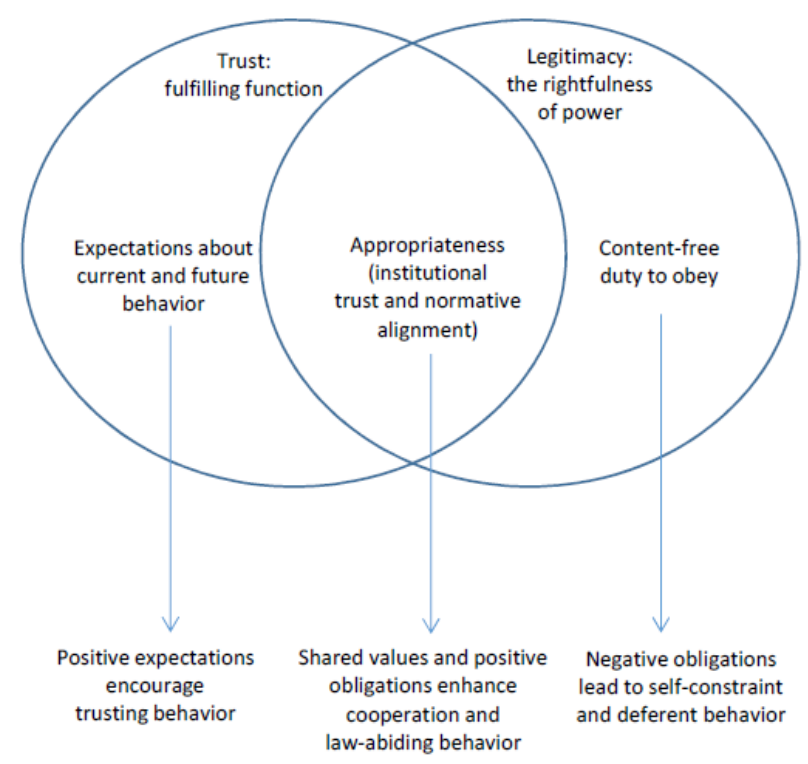

In spite of the tremendous benefits that civilian trust and confidence in local law enforcement may generate, public distrust in law enforcement appears now to be at or near its highest level in modern memory; political, thought, and law enforcement leaders are calling for a resurgence of public trust in law enforcement (Associated Press, 2015; Dai \& Johnson, 2009; Frank, Brandl, Cullen, \& Stichman, 1996; Gillespie, 2015; Ludlow, 2014; Pew Research Center/USA Today, 2014; Weitzer \& Hasisi, 2008; Weitzer, Tuch, \& Skogan, 2008). These and other commentators note that distrust of law enforcement is particularly prevalent (Newport, 2014; Peck, 2015, at 174; Ruffin, 2016; Smith, 2005; Webb \& Marshall, 1995) among Blacks: "Fully 70\% of blacks say police 


\section{CONFIDENCE IN LAW ENFORCEMENT}

departments around the country do a poor job in holding officers accountable for misconduct" (Pew Research Center/USA Today, 2014, p. 2). "Race is inextricably tied to perceptions of injustice in American society (MacDonald, Stokes, Ridgeway, \& Riley, 2007, p. 2581)." "America's history of policing and criminal justice administration has long been blemished by racial stratification and discriminatory actions motivated by racial bias" (Kennedy, et al., 2017, p. 12). Some argue this distrust stems from generalized legal cynicism or beliefs of unfair treatment (Hough, 2012; Tyler, 2005), or from uncomfortable or inappropriate earlier contacts that civilian survey respondents of color had with law enforcement (Callanan \& Rosenberger, 2011; Cochran \& Warren, 2011; Correia, Reisig, \& Lovrich, 1996; Hinds, 2009; Schuck, Rosenbaum, \& Hawkins, 2008), or from an allegedly diminished sense among communities of color of an obligation to obey police (Antrobus, Bradford, Murphy, \& Sargeant, 2015; Drake, 2015; Sargeant, 2017). Nonetheless, researchers have eliminated measurement error as the source of this racial gap in civilian confidence in local law enforcement; that racial gap is not a mirage (Posick, Rocque, \& McDevitt, 2013). One researcher attributed the trust gap to what she deemed "three common features" in societies experiencing that gap: “economic equality, spatial segregation, and political disenfranchisement" (Barker, 2016, p. 11). Finally, Regulus, Taylor, and Jackson (2001) remind us all that although AfricanAmerican attitudes toward police generally lag majority attitudes, a numerical majority of African-Americans hold positive opinions about law enforcement (pp. 185-187, 197). Across the United States, in cities large and small and whether there is a large or small minority population, there is a dramatic deficit between the trust or confidence White and Black civilians, respectively, have in their local law enforcement. Taylor, 


\section{CONFIDENCE IN LAW ENFORCEMENT}

Wyant, and Lockwood (2015) found that "Whites and nonwhites perceive that they are policed differently, even in places where minorities are few in number (p. 235)." Miller (2018), in a study of aggregated trust in and satisfaction with police, found that cities with higher minority populations - by percent - had lower police trust/satisfaction scores (p. 3). In a recent Pew Charitable Trusts study, the deficit is clear and consistent (Ekins, 2017a, pp. 1-4, 12, 14, 34-35, 39, 42-43):

Table 1. Key Components of the Racial Confidence Gap (percentages of respondents)

White Black Hispanic

I have a favorable view of the police lethal force

I believe police tactics are generally too harsh

I believe my local police dept is highly courteous

I believe local police treat all races equally

I know someone who was physically mistreated by police

The criminal justice system treats all racial groups equally

I expect police to treat my race worse than other races

I expect to personally receive equal treatment from police

I would definitely report a crime

Most police officers believe they are above the law

Police are generally not held accountable for their misconduct
68

35

$68 \quad 40 \quad 59$

$73 \quad 54$

26

56

33

62

43

49

64

31

42

18

39

27

49

17

27

6

33

13

77

60

72

78

54

57

46

61

61

43
64 


\section{CONFIDENCE IN LAW ENFORCEMENT}

Table 2. The Racial Dimensions of Civilian Trust / Confidence (in percent)

\begin{tabular}{lccc}
\hline & Black & White & Difference \\
\cline { 2 - 4 } Ekins (2017a) & 40 & 68 & 28 \\
Norman (2017) & 30 & 61 & 31 \\
Auter (2016) & 66 & 82 & 16 \\
Morin \& Stepler (2016) & 55 & 81 & 26 \\
Newport (2016) & 29 & 58 & 29 \\
Jones (2016) & 30 & 57 & 27 \\
\hline
\end{tabular}

Furthermore, the phenomenon that Blacks had a significantly lower confidence in local law enforcement appears to be international in scope in countries where Blacks were in the minority (Brown \& Benedict, 2002).

However, race may be an imperfect variable here inasmuch as race can be correlated with (or a confounding variable with respect to) other relevant variables including negative contacts with police (Gau, 2010; Reisig \& Parks, 2000; Reisig \& Parks, 2002; Shelley, Hogan, Unnithan, \& Stretesky, 2013; Wu, Sun, \& Triplett, 2009); fear of crime in the respondent's own neighborhood (Perkins, 2016); lack of feelings of personal safety or social cohesion in respondents' own communities (Auter, 2016; Bradford \& Myhill, 2015; Perkins, 2016); quality of life, generally (Reisig \& Parks, 2000, 2002); lack of mirror image of race on the local police force (Forster-Towne, 2012); perceptions of decay, disorder, or disadvantage in one's own community (Boateng, Lee, \& Abess, 2016; Perkins, 2016; Reisig \& Parks, 2000, 2002; Wu, Sun, \& Triplett, 2009); felt obligations to obey the law and police (Baker, et al., 2015); history or perceptions of procedural justice/injustice and fair/unfair treatment (Baker, et al., 2015; 


\section{CONFIDENCE IN LAW ENFORCEMENT}

Bowling \& Phillips, 2003; Bradford \& Myhill, 2015; Lee, 2017; Nix, Wolfe, Rojek, \& Kaminski, 2015; Schulenberg, Chenier, Buffone, \& Wojciechowski, 2017; Tyler \& Huo, 2002, pp. 49, 57; Wolfe, Nix, Kaminski, \& Rojek, 2016); civilian impressions of police accountability (DeAngelis \& Wolf, 2016); exposure to media reporting on police misconduct (Wu, 2010, p. 778); and enhanced fear of deportation in relevant sub-groups (Becerra, Wagaman, Androff, Messing, \& Castillo, 2017; Wu, Sun, \& Smith, 2011, pp. 768-769). More searching inquiries (Bottoms \& Tankebe, 2012; Harkin, 2015; Murphy, 2017) have begun to doubt the direct link alleging that perceptions of procedural justice lead to confidence in law enforcement. Those researchers question the direction and authenticity of the correlation between procedural justice and confidence. They posit that those who are in the majority are most likely to view law enforcement as meting out procedural justice (because it works out for them and their same-race peers) and in the same breath express confidence in local law enforcement, not because that confidence is driven by procedural justice per se but because that perception of procedural justice is driven by their standing as a member of the favored and protected and more "fairly" treated sub-group. Taylor, Wyant, and Lockwood (2015) also found that this race-specific confidence in local law enforcement is a feedback loop that bootstraps itself with each iteration. "[I]t is plausible that these residents [who are members of the majority or superordinate group] infer from their experiences of being treated fairly by local police that these officers also are operating effectively (p. 238)."

MacDonald, Stokes, et al. (2007) found that race is a key predictor of citizen confidence in local law enforcement even after removing neighborhood context variables from the models; those neighborhood context variables often confound with race. 


\section{CONFIDENCE IN LAW ENFORCEMENT}

However, Shelley, Hogan, Unnithan, and Stretesky (2013), in studying a statewide law enforcement agency (Colorado State Highway Patrol), found that race was less significant than in municipal agency models, implying that the municipal models are not measuring the impact of race on confidence in law enforcement so much as they are measuring neighborhood context impacts in those municipal communities in which many civilians of color reside.

Rosenbaum, Schuck, et al. (2005) found that contacts with police, whether positive or negative, were insufficient to overcome basal levels of trust or distrust in law enforcement. " $[\mathrm{C}]$ hanging people's attitudes about the police will require more than changing their direct experience with the police. The problem is more deeply rooted in the social fabric of the community (p. 360)." Salvatore, Markowitz, and Kelly (2013) found similarly that personal experiences of police incivility arising from recent contacts did not adversely impact citizen impressions of the criminal justice system overall (pp. 11-12). Those perceptions are too stable to be overwhelmed by one or even a few recent contacts. At the beginning of the current millennium, the criminal justice system was the public institution garnering the least public confidence according to Gallup polling data, $23 \%$ confidence in the criminal justice system compared to $57 \%$ confidence in the police (Sherman, 2001, p. 8; see also Sherman, 2002).

Note that Skogan (2009) posited that the causation worked, in a sense, in the reverse; that is, that increasing confidence in the police leads to reduced concerns about crime in one's neighborhood (pp. 301, 314).

Johnson (2015) presented a meta-analysis of 27 key published studies of civilian satisfaction with law enforcement at the individual municipality level and found that the 


\section{CONFIDENCE IN LAW ENFORCEMENT}

strongest single factor that could drive satisfaction downward was a recent negative law enforcement contact affecting the respondent or the respondent's close friend or family member, citing also that the respondent's perception of public disorder in respondent's own neighborhood was the second strongest factor. The 27 individual city studies in the Johnson (2015) meta-analysis were Barboza (2012); Cao (2015); Dai \& Jhang (2016); Dai \& Johnson (2009); Dukes, Portillo, \& Miles (2009); Garcia \& Cao (2005); Gau (2010); Haberman, Groff, Ratcliffe, \& Sorg (2016); Huebner, Schafer, \& Bynum (2004); Lai \& Zhao (2010); Lord, Kuhns, \& Friday (2009); McCluskey, McCluskey, \& Enriquez (2008); Miller, Davis, Henderson, Markovic, \& Ortiz (2005); Piatkowski (2015); Posick, Roque, \& McDevitt (2013); Reisig \& Chandek (2001); Reisig \& Parks (2000); Romain \& Hassell (2014); Rosenbaum, Schuck, et al. (2005); Schuck, Rosenbaum, \& Hawkins (2008); Shelley, Hogan, et al. (2013); Smith (2005); Weitzer \& Tuch (2004, 2005); Wu (2010); Wu, Sun, \& Smith (2011); Wu, Sun, \& Triplett (2009).

A good deal of research has found similar correlations between various of these variables and Latinos, Hispanics, and Mexican-Americans (Barboza, 2012; Barrick, 2014; Becerra, et al., 2017).

Also, studies in several other countries, assessed one country at a time, have demonstrated that similar variables are significantly correlated with confidence in local law enforcement: Canada (Clark, Davidson, Hanrahan, \& Taylor, 2017; Cheng, 2015; Maslov, 2015); Australia (Dai \& Jhang, 2016); Brazil (Sampaio, De-Losso, Cunha, \& dePieri, 2015); Ghana (Tankebe, 2010); and others.

"Public support is essential to effective policing and crime control" (Jefferis, Butcher, \& Hanley, 2011, p. 1). No matter the genesis, "Research consistently shows that 


\section{CONFIDENCE IN LAW ENFORCEMENT}

minorities are more likely than whites to view law enforcement with suspicion and distrust" (Philpott, 2016, p. 106). Other researchers have expanded on that point (Estrada, 2015; NIJ, 2013; Schafer, Huebner, \& Bynum, 2003; Schuck \& Rosenbaum, 2005). Public distrust drives perceptions of police legitimacy (DeAngelis \& Kupchik, 2007; Jackson, 2015; Miller \& Davis, 2008; Tankebe, 2013; Tyler, 2002, 2006). And membership in a "visible minority" enhances that police mistrust (Cao, 2011; Lai \& Zhao, 2010; Wu, 2014; Zhao, Lai, Ren, \& Lawton, 2015). Furthermore, that distrust has been consistent since the 1970s and does not seem to be fading with time, particularly given more recent high-profile claims of excessive use of police force, including those incidents involving police killings of unarmed Black men and boys (Ekins, 2017b; Estrada, 2015; Hannah-Jones, 2015; Holland, 2014; Natarajan, 2014; Warren, 2010). In approximate reverse chronological order, the highest profile officer-involved killings of unarmed Black men and boys from 2014-2018, many of whom have become household names, include Stephon Clark in Sacramento, California, 2018 (Cobb, 2018); Botham Shem Jean in Dallas, Texas, 2018 (Branham, 2018); Jean Pedro Pierre in Broward County, Florida, 2017 (Madan, 2017); Paul O’Neal in Chicago, Illinois 2017 (Charles, 2018); Donnell Thompson in Los Angeles, California, 2016 (Ferner, 2016); Alton Sterling in Baton Rouge, Louisiana, 2016 (Kunzelman \& Izaguirre, 2018); Philando Castile in Falcon Heights, Minnesota, 2016 (Barajas, 2017); Keith Scott in Charlotte, North Carolina, 2016 (Swaine, 2016); Christian Taylor in Arlington, Texas, 2015 (McGee \& Fernandez, 2015); Samuel DeBose in Cincinnati, Ohio, 2015 (Berman, 2017); Freddie Gray in Baltimore, Maryland, 2015 (Ruiz, 2017); Walter Scott in North Charleston, South Carolina, 2015 (Vann \& Ortiz, 2017); Eric Garner in Cleveland, Ohio, 


\section{CONFIDENCE IN LAW ENFORCEMENT}

2014 (Horwitz, 2014); Laquan MacDonald in Chicago, Illinois, 2014 (Smith, 2018); Akai Gurley in Brooklyn, New York, 2014 (Bacon \& Eversley, 2016); Michael Brown in Ferguson, Missouri, 2014 (USDOJ, 2015); and Tamir Rice in Cleveland, Ohio, 2014 (Nelson, 2014). Many officers are never criminally charged, but even those officers charged for their involvement in these killings often are acquitted or escape serious consequences (Goldberg, 2018). On a hopeful note, some commentators have noticed that through the middle of 2018 the number of such fatal police contacts with unarmed persons had "significantly declined" (Sullivan, Tate, \& Jenkins, 2018).

Using 2013 LEMAS data on minority percent of sworn officers in a sample of 160 large city police departments and 2010 United States Census population by race for those cities, the following chart depicts the strong positive (or right) skewedness of the African-American Racial Mirror Index among large city law enforcement agencies:

Figure 3. Racial Mirror Index-African American ("RMI-AA")

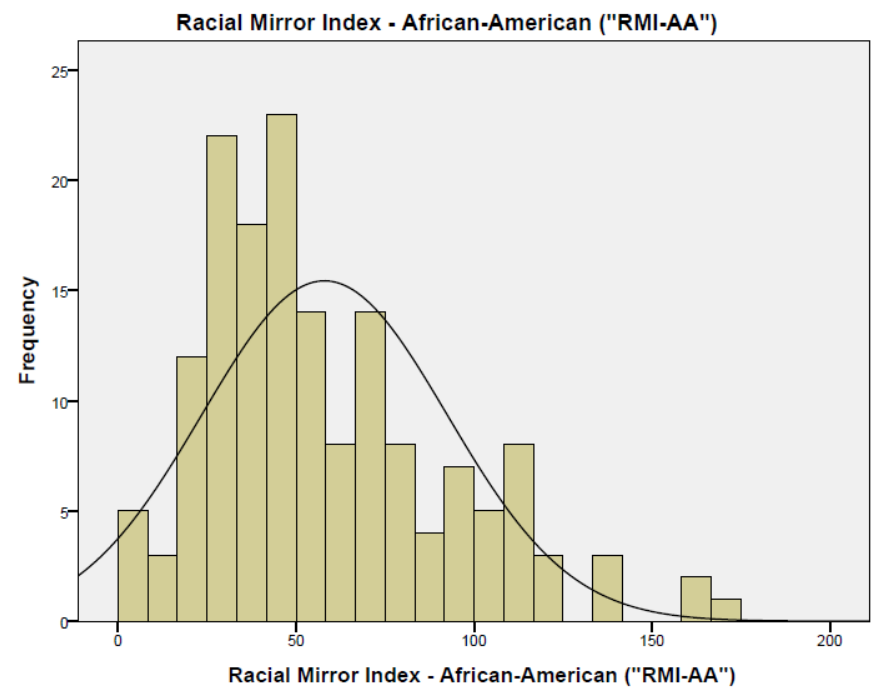

Note that just 22 of the 160 large cities in this sample exhibited a RMI-AA of greater than 100 (that is, had a greater percent of sworn officers who were Black than the percent of Black persons in the total city population); thus, in this sample, in fully $86 \%$ of 160 


\section{CONFIDENCE IN LAW ENFORCEMENT}

large cities, Black persons were underrepresented among sworn officers in the local law enforcement agency. Willow and Cohen (2017) determined that Black underrepresentation in sworn officer populations was strongly correlated with percent of Black persons in the community served; that is, the larger the Black population, the greater the likelihood of underrepresentation. In mitigation, the authors found that the larger the agency the more willing it was to address underrepresentation with aggressive minority officer hiring campaigns; therefore, smaller communities with large Black percent populations were most likely to exhibit extensive and intractable underrepresentation (Willow \& Cohen, 2017, pp. 13-14).

\section{The Impact of the Racial Mirror Index on Excessive Force Complaints}

Although this study addresses the Racial Mirror Index per se and its implications for minority civilian confidence in local law enforcement, two studies have assessed correlations between minority underrepresentation on local law enforcement within a community and excessive use of force complaints against local law enforcement within those communities. Hickman and Piquero (2009) used LEMAS 2003 data on 496 police departments in larger metropolitan areas to assess the impact of minority underrepresentation on rates of excessive use of force complaints in those metropolitan areas (both variables - minority representation and number of use of force complaints were conveniently captured in the LEMAS data). They also considered a number of subsidiary organizational and administrative characteristics in those police departments to determine their roles in the complaint rates. Although the researchers found complaint rates were correlated with communities' internal affairs approaches, violent crime rates, degree of organizational formalization, and officer unionization, Hickman and Piquero 


\section{CONFIDENCE IN LAW ENFORCEMENT}

(2009) found that minority underrepresentation was not statistically correlated with complaint rates.

A subsequent study, by Trochmann and Gover (2016), used LEMAS 2007 data for a smaller sample of just 100 large metropolitan area police departments. They found that the relationship between minority representation and frequency of use of force complaints was negative, as they had expected, and the relationship was statistically significant albeit with a small effect size (p. 782). They also noted that city "fixedeffects," when added to their regression model, predominate over minority representation in having an impact on the rate of excessive force complaints (p. 783).

These studies used extant data collected in the LEMAS process to explore the impact of minority representation on excessive force complaints. However, civilian confidence is not collected in the LEMAS survey. Numerous national surveys are conducted in which law enforcement are the respondents (NPRP, 2018; LEMAS, 2016; LEMAS, 2013), but few surveys use civilian respondents at the granular, city level where respondent-level data is available to facilitate further statistical manipulation. Thus, the studies to date in this area have taken a somewhat easy route by sidestepping evaluation of the impact of minority representation on civilian confidence, because civilian confidence databases by city and using a single transferrable definition for confidence do not exist. As a result, those city police departments that have undertaken discreet "citizen satisfaction surveys" that strive to quantify citizen satisfaction with local law enforcement in that one community are often the only extant citizen satisfaction data by city. Further, those relatively few citizen satisfaction surveys do not typically report responses by race of respondent and are not comparable one with the other because they 


\section{CONFIDENCE IN LAW ENFORCEMENT}

define citizen satisfaction, trust, or confidence in myriad ways using a wide range of survey questions or survey items and using various aggregation approaches. Indeed, at least one law enforcement agency in each of the fifty states has conducted a civilian satisfaction survey; an example civil satisfaction survey for each state is presented in table 3 below (the United States Department of Justice played an early and central role in designing and promoting the community satisfaction surveys approach (Weisel, 1999)):

Table 3: Jurisdiction-Level Citizen Satisfaction Surveys - A Subset

\begin{tabular}{|c|c|c|}
\hline State & Jurisdiction & Citation \\
\hline Alabama & Dothan & Bradley, Brooks, \& Allen (2017) \\
\hline Alaska & Anchorage & Flexman-Evans (2009) \\
\hline Arizona & Pinal County & Pinal County (2015) \\
\hline Arkansas & 4 counties & Fitzpatrick \& Myrstol (2010) \\
\hline California & Hayward & Hayward Police (2017) \\
\hline Colorado & Pueblo & ETC Institute (2018c) \\
\hline Connecticut & Waterford & The Research Bureau, Inc. (2011) \\
\hline Delaware & Milford & National Research Center, Inc. (2017a) \\
\hline Florida & North Palm Beach & Village of North Palm Beach (2009-09) \\
\hline Georgia & Thomasville & Gresham, Milford, \& Fowler (2017) \\
\hline Hawai'i & Hawai'i Island & Hawai’i Police Department (2016) \\
\hline Idaho & Hailey & Richard Caplan \& Associates (2009) \\
\hline Illinois & Buffalo Grove & Casstevens (2017) \\
\hline Indiana & Brownsburg & National Research Center, Inc. (2015) \\
\hline Iowa & Iowa City & Iowa City Police Department (2016) \\
\hline Kansas & Andover & Andover Police Department (2016) \\
\hline Kentucky & Louisville & Keeling \& Swartz (2014) \\
\hline Louisiana & New Orleans & WPA Intelligence (2018) \\
\hline Maine & South Portland & The Research Bureau (2011) \\
\hline Maryland & Baltimore & Cotton, Haynes, \& Wells (2012) \\
\hline Massachusetts & Wrentham & Gomez, Jean-Charles, Zhao, Zhao, \& Zou (2012) \\
\hline Michigan & Rochester & City of Rochester, Michigan (2017) \\
\hline Minnesota & Minneapolis & $\begin{array}{l}\text { Peterson, Peterson, Bartholomay, Huckaby, \& Martin-Rogers } \\
\qquad(2016)\end{array}$ \\
\hline Mississippi & Jackson & Davis, Camel, Mozee, \& Granger (2016) \\
\hline Missouri & Columbia & ETC Institute (2018a) \\
\hline Montana & Missoula & Haack (2009) \\
\hline Nebraska & Lincoln & Pytlik-Zillig, Walther, \& Kawamoto (2017) \\
\hline Nevada & Las Vegas & ETC Institute (2018b) \\
\hline $\begin{array}{c}\text { New } \\
\text { Hampshire }\end{array}$ & Hollis & Hollis Police Department (2018) \\
\hline
\end{tabular}




\section{CONFIDENCE IN LAW ENFORCEMENT}

\begin{tabular}{|c|c|c|}
\hline New Jersey & Evesham & Evesham Police Department (2018) \\
\hline New Mexico & Rio Rancho & National Research Center, Inc. (2017b) \\
\hline New York & Town of Dewitt & Machado (2013) \\
\hline North Carolina & Durham & ETC Institute (2016) \\
\hline North Dakota & Mandan & Mandan Tomorrow Committee (2017) \\
\hline Ohio & Kettering & Kettering Police and Communication Center (2017) \\
\hline Oklahoma & Edmond & National Research Center, Inc. (2016) \\
\hline Oregon & Salem & DHM Research (2018) \\
\hline Pennsylvania & Warren & City of Warren PA (2017) \\
\hline Rhode Island & Warwick & Warwick Police Department (2017) \\
\hline South Carolina & Greenville & Burnap \& Research Strategies, Inc. (2017) \\
\hline South Dakota & Sioux Falls & National Research Center (2017c) \\
\hline Tennessee & Sevierville & National Research Center, Inc. (2013a) \\
\hline Texas & Jacksonville & Jacksonville Texas Police Department (2017) \\
\hline Utah & Park City & National Research Center, Inc. (2013b) \\
\hline Vermont & Bennington & Town of Bennington (2016) \\
\hline Virginia & Fairfax County & Lum, Johnson, Nichols, Grieco, \& Wu (2016) \\
\hline $\begin{array}{l}\text { Washington } \\
\text { State }\end{array}$ & Seattle & Seattle Police Department (2018) \\
\hline West Virginia & Morgantown & National Research Center, Inc. (2006) \\
\hline Wisconsin & Milwaukee & Cera \& Coleman (2014) \\
\hline Wyoming & Gillette & Gillette Wyoming Communications Division (2017) \\
\hline
\end{tabular}

Therefore, these extant citizen satisfaction surveys cannot be meaningfully compared as in a regression equation against the Racial Mirror Index. The proposed study seeks to fill that void by forging a research path in a new direction striving to use a single consistent definition for civilian confidence and a single universal survey instrument to obtain a representative dataset of civilian confidence for a small subset of American metropolitan areas. The best measure of civilian confidence in local law enforcement has been addressed at length in the literature as discussed in the next section.

\section{Measuring Civilian Confidence in Local Law Enforcement}

"Confidence" in local law enforcement has often been measured on a continuum along various measures, including confidence, trust, satisfaction, legitimacy, and others (Dukes, et al., 2009; Giblin, 2003; Jackson \& Gau, 2016; Skogan, 2005; Weitzer \& Tuch, 


\section{CONFIDENCE IN LAW ENFORCEMENT}

2005). Satisfaction surveys regarding individual local law enforcement agencies have been popular since the mid-1960s (NIJ, 2002; Reisig \& Chandek, 2001). Tankebe, Reisig, and Wang (2016) noted that perceptions of police legitimacy were positively correlated with a felt obligation to obey and cooperate with the police and comply with the law and that police legitimacy incorporates police lawfulness, distributive fairness, procedural fairness, and effectiveness (pp. 11, 19). Ho and Cho (2016) tied satisfaction even more directly to law enforcement communication with the public about law enforcement effectiveness and achievements; the researchers argued that inasmuch as civilians are largely apathetic about law enforcement, positive communications could both educate civilians about past police achievements and drive more positive civilian satisfaction (p. 229). Yet many commentators now consider "confidence" to be the most telling and accurate yardstick to employ (although confidence is closely allied with trust) (Antrobus, et al., 2015; Bouranta, et al., 2015; Cao, 2011, 2015; Garcia \& Cao, 2005; Hinds, 2009; Jefferis, et al., 2011; Lai \& Zhao, 2010; Tankebe, 2010, 2013; Zhao, et al., 2015). As one example, Cambridge scholar Justice Tankebe measured the impact of police corruption in Ghana on the public's confidence in that nation's law enforcement (Tankebe, 2010). Tankebe's work (based in turn on the earlier work of Sunshine and Tyler (2003)) was underscored by a more recent study determining that among the three measures classically used to assess public perceptions of law enforcement (confidence, trust, and satisfaction), confidence (the measure used by Tankebe, 2010, and the measure playing a central role in this proposed study) was the superior measure for assessing overall public attitudes toward law enforcement (Cao, 2015). This proposed study measures civilian confidence in local law enforcement using the categories, definitions, 


\section{CONFIDENCE IN LAW ENFORCEMENT}

and surveys utilized in Tankebe's $(2010,2013)$ work, but also using aggregated concepts, including confidence as a single item in the survey.

Civilian confidence or trust in local law enforcement is a complex system. "One thing we discovered very clearly is that there are no universally accepted methodologies to measure or respond to trust, nor even any that we would deem to be best practices. It seems societies everywhere are still grappling with this question (CACP, 2017a, p. 2).” At the individual civilian level, trust appears to be strongly influenced by the individual's race; recent adverse contacts with law enforcement (Ozkan's (2016) brief meta-study summarized the key features of satisfaction scholarship in broad brush); exposure to media depictions of law enforcement behavior (one study found that even large variations in media coverage of local law enforcement misconduct did not materially affect public

confidence in or satisfaction with local law enforcement. Miller, Davis, et al. (2005)); and neighborhood decay and other local neighborhood contexts (many studies have found neighborhood contexts, decay, and fear of crime as significantly correlated with civilian trust and confidence in local law enforcement) (Auter, 2016; Boateng, Lee, \& Abess, 2016; Bradford \& Myhill, 2015; Perkins, 2016; Reisig \& Parks, 2000, 2002; Wu, Sun, \& Triplett, 2009).

"Satisfaction" appears to be a retrospective assessment (as in, "I am satisfied with law enforcement's past performance"), but "confidence" and "trust" appear to be prospective (as in, "I am confident - or, I trust - that I will be treated fairly in future encounters with law enforcement”) (Bradford \& Myhill, 2015). Alberton and Gorey (2018) found in a meta-study of past work that in properly specified models, it was clear that contact with law enforcement was stronger than race as a predictor of confidence in 


\section{CONFIDENCE IN LAW ENFORCEMENT}

law enforcement, but that result could not be appreciated unless the nature of the contact

was divided into quadrants based on whether the contact was individual or policeinitiated and whether the contact was positive or negative. That Alberton and Gorey (2018) meta-study was presaged by Reisig and Chandek (2001), who called for multi-city analyses to better assess the impact of contacts on confidence. Brown and Benedict (2002), in a critical meta-study, found that just four variables (as the authors specified them) were significantly correlated with civilian confidence in law enforcement: age, own contacts with police, neighborhood contexts, and race.

Interestingly, in a large cross-national study across 50 countries and over 69,000 respondents, Cao, Lai, and Zhao (2012) found that although the individual drivers of civilian trust in law enforcement, namely age, gender, marital status, and employment, were still salient and significant at an individual level, these drivers were dwarfed by country-level realities, such as degree of democratic rule. The current study, addressing American law enforcement only, only considers individual and neighborhood-level variables. Jang, Joo, and Zhao (2010), in a separate cross-national, country-level study, similarly found that as the degree of democratic governance in a country increased, civilian confidence in local law enforcement also increased. Morris (2011) assessed 53 countries in 2011 and found that both degree of perceived government corruption and degree of racial diversity suppressed civilian confidence in local police and degree of democracy improved civilian confidence in local police. Solakoglu (2016) found that degree of democracy and law enforcement transparency were the key correlates of perceptions of police effectiveness and trust in the local police in two European countries, Belgium and the Netherlands (pp. 53-54). 


\section{CONFIDENCE IN LAW ENFORCEMENT}

One of the dilemmas for civilian confidence researchers is to identify cities willing to participate in such studies, particularly when confidence is evaluated separately by civilian race. My research has found dozens of individual city-level "satisfaction" surveys and reports on survey results in many individual cities, but I have found none that report satisfaction in local law enforcement by race of civilian respondents. The last major multi-city study of satisfaction by race was conducted in 1998 and published in 1999 (Smith, Steadman, et al., 1999). The twelve cities in the study were Chicago, Illinois; Kansas City, Kansas; Knoxville, Tennessee; Los Angeles, California; Madison, Wisconsin; New York, New York; San Diego, California; Savannah, Georgia; Spokane, Washington; Springfield, Massachusetts; Tucson, Arizona; and Washington D.C. (p. 11). To conduct that study, the researchers appended a civilian satisfaction module onto the National Crime Victimization Survey (pp. iii-iv). They queried approximately 1,000 residents in each of the twelve cities on quality of life, fear of crime, neighborhood conditions, personal contacts with police, and satisfaction with the police (pp. 11-13, 15$19,23,25)$. The results highlighted many of the same findings that had been made nationwide - that each of these factors was correlated with satisfaction with local police (p. 26). The current study used the Smith, Steadman, et al. (1999) study as a springboard, but better delineated the independent variables based on research since 1999, uses confidence rather than satisfaction as the dependent variable, and cross-tabulates the findings with each city's Racial Mirror Index for African-Americans.

\section{Summary}

As this literature review illustrates, scholars have examined the impact of race on frequency of use of force complaints (finding little or no significant correlation), civilian 


\section{CONFIDENCE IN LAW ENFORCEMENT}

satisfaction with law enforcement (finding that African-American civilians, as a group, exhibit lower trust, satisfaction, or confidence in law enforcement), and civilian perceptions of procedural justice (that those perceptions are modified by race and community contexts). The literature review also demonstrated that civilian confidence is superior to trust and satisfaction as a measure of civilian perceptions of the efficacy of and the justice delivered by law enforcement. However, there is no nationwide database that has measured civilian confidence on a consistent basis using universal and therefore comparable and statistically useful definitions and survey questions or items; there is obviously no nationwide database of civilian confidence in local law enforcement by race. The extant literature presented here has thus provided the backdrop for the proposed study but also has illuminated the gap in the research that this proposed study is intended to fill. The gap is epitomized in the work of Berube and Holmes (2016), which used LEMAS and Governing data to report on the quantum of underrepresentation of minorities among sworn law enforcement officers but stopped short of using those data to draw any implications for excess force, confidence, or other key law enforcement constructs. Using an Internet panel survey of African-Americans nationwide, this study is intended to determine the impact on African-American confidence in local law enforcement serving a community when that community's African-Americans are underrepresented among sworn police officers serving in the local law enforcement agency in that community.

This is an exploratory study; however, the author has specified the following research questions related to the correlation between RMI-AA and African-American confidence in local law enforcement. 


\section{CONFIDENCE IN LAW ENFORCEMENT}

\section{Research Questions}

RQ1: Using Exploratory Factor Analysis, which factors most efficiently summarize the variation in the measured variables (the survey responses) related to African-American civilian confidence in local law enforcement.

RQ2: Are the factors derived in the Exploratory Factor Analysis for research question 1 strongly associated with African-American civilian (a) confidence, (b) satisfaction, and (c) trust in local law enforcement.

RQ3: Do African-Americans living in communities served by law enforcement agencies wherein African-Americans are underrepresented among sworn officers in those agencies have lower confidence in those local law enforcement agencies.

RQ4: When African-American underrepresentation among sworn officers in local law enforcement is modeled with other variables known to correlate with civilian confidence in law enforcement (including neighborhood context, fear of crime, recent adverse police contact), is underrepresentation still - or does it become - a significant predictor of African-American civilian confidence in local law enforcement. 


\section{CONFIDENCE IN LAW ENFORCEMENT}

\section{Chapter 3}

\section{Methodology}

This exploratory study applies a cross-sectional survey design with the survey hosted online and qualifying respondents (African-American adults) self-selected from a commercial survey panel. Extant data on minority underrepresentation in municipalities where respondents reside were coded by the researcher based on data gathered from federal law enforcement and census sources. Civilian confidence was assessed using participants' responses to the online questionnaire.

\section{Participants}

Recent high-profile incidents of White law enforcement officer violence upon unarmed African-American civilians has occurred in some communities where the racial/ethnic profile of the law enforcement agencies serving each community markedly fails to mirror the racial/ethnic profile of the community served. In many of those and other communities with similar profiles, civilian confidence in local law enforcement is anecdotally believed to be low, particularly among minority groups (Bolten, 2015; Callanan \& Rosenberger, 2011; Hannah-Jones, 2015; Huebner, Schafer, \& Bynum, 2004; Jones \& Rowe, 2015; NIJ, 2013; Schafer, Huebner, \& Bynum, 2003; Schuck \& Rosenbaum, 2005; Wu, 2014). This study will focus on two key metrics regarding the respondents: (1) Racial Mirror Index among African-American civilians ("RMI-AA”) for each respondent's community; and (2) African-American civilian confidence, trust, and satisfaction in the local police serving each respondent's community. In that sense, there are several categories of "participants."

Although there were some early adopters of web-based surveying approaches 


\section{CONFIDENCE IN LAW ENFORCEMENT}

relevant to law enforcement, such as Rosenbaum, Schuck, Lawrence, and Hartnett (2011) and Rosenbaum, Schuck, Graziano, and Stephens (2008), online and panel surveying have more recently grown in popularity among social science and criminal justice researchers (Gottlieb, 2017; Perkins, 2016; Redfern, 2014; Riccucci, VanRyzin, \& Lavena, 2014; Simmons \& Bobo, 2015; Sousa, Miethe, \& Sakiyama, 2018). Sousa, Miethe, and Sakiyama (2018) used the Amazon Mechanical Turk (“MTurk”) online survey panel platform to generate respondents for their attitudinal survey, finding that although some of the demographics did not consistently mirror the population's demographics, the results were consistent with prior studies (p. 102, note 2). In settling on the MTurk survey panel approach, Sousa, Miethe, and Sakiyama (2018) considered the consistent and positive MTurk survey panel approach assessments reached by Heen, Lieberman, and Miethe (2014).

Gottlieb (2017) thoroughly investigated studies regarding the use of MTurk in social science scholarship. He found that MTurk's internal and external validity were similar to classic survey methods at a far lower cost and at far faster turnaround times (pp. 643-644). In application, Gottlieb (2017) posed several attitudinal questions to his MTurk panels to assess their between-group responses to reforming the criminal justice system for non-violent offenders. He randomly assigned his respondents to one of six sub-groups based on the cue or messaging frame that each received prior to responding to the survey, such as "structural causes of crime," impact of parental incarceration on children, and costs of incarceration. His results, using ordinal logistic regression modeling, showed that MTurk sampling could yield reliable and meaningful results when assessing respondents' criminal justice-related attitudes. 


\section{CONFIDENCE IN LAW ENFORCEMENT}

Simmons and Bobo (2015) explored public attitudes toward racial and social inequality by comparing internet survey responses and face-to-face survey techniques (pp. 366-367). As between face-to-face and internet surveys of public racial inequality attitudes, the researchers found that demographic characteristics of respondents were "roughly equivalent"; internet respondents tended to be more politically engaged, ideologically extreme, and racially and socially conservative; internet-based models tended to explain more of the variances; and the more specific the attitudinal questions asked in the survey, the more similar were the responses across face-to-face and internet survey modalities (pp. 380-381). As the authors noted, "we find the differences between the [face-to-face and internet survey] models to be substantively minor . . . trivial (p. 379).”

Redfern (2014) used the Survey Monkey Audience panel approach over a threeday period to secure respondents to survey law enforcement attitudes toward transgender persons (p. 3). Using a 22-question survey, similar in size to the survey in this study, the author was able to assess in a descriptive sense officers' experiences with and attitudes toward the target group (pp. 6-7).

Two Internet-based attitude surveys related to public attitudes toward local police were most relevant and similar to the study herein. Perkins (2016) used the Survey Monkey online data collection tool and other survey techniques to assess the degree to which civilian attitudes toward police (including confidence in local police) varies across neighborhoods in York, United Kingdom (p. 115). The study found that civilian confidence in local police was closely correlated with respondents' attitudes about their community context, including fear of crime, and local area problems, cohesion, and 


\section{CONFIDENCE IN LAW ENFORCEMENT}

safety (pp. 115, 122-123). Riccucci, et al. (2014) used an online survey approach to assess public perceptions of police legitimacy as they relate to gender representativeness in a hypothetical domestic violence unit in the local police department (pp. 537, 541545). The authors found that the public perceives a police agency's domestic violence unit as more legitimate when female officers are well-represented in that unit (p. 549).

From a more generic perspective, many researchers have compared internet-based and classic mailed and in-person or by-telephone survey techniques along key reliability dimensions, including demographic representativeness, internal (test/re-test) validity, external validity, response rates, time spent per question, generalizability, and costeffectiveness (Ballard \& Prine, 2002; Buhrmester, Kwang, \& Gosling, 2016; Gottlieb, 2017; Heen, Lieberman, \& Miethe, 2014; Lowry, D’Arcy, Hammer, \& Moody, 2016; Mullinix, Leeper, Druckman, \& Freese, 2015; Paolacci, Chandler, \& Ipeirotis, 2010; Simmons \& Bobo, 2015). Those researchers consistently found that online survey techniques versus traditional in-person, mailed, or telephone surveying, were "roughly equivalent" (Simmons \& Bobo, 2015); and "at least as representative" (Paolucci, et al., 2010). Those researchers found that benefits and reduced costs of online survey methods outweigh any critiques of online methods (Lowry, D’Arcy, et al., 2016); online surveys were an efficient, affordable, and practical alternative (Heen, et al., 2014); online surveys were far more representative of the total population than traditional college student respondent pools (Gottlieb, 2017); online surveys using panels were at least as representative of the total population as either classic survey approaches or online surveys without panels (Buhrmester, et al., 2016); and using online versus mailed surveys "did not significantly affect [the] answers" that respondents provided (Ballard \& Prine, 


\section{CONFIDENCE IN LAW ENFORCEMENT}

2002).

Using Amazon Mechanical Turk ("MTurk”) and TurkPrime, the Qualtrics-based survey was made available to African-American adult MTurk panel members who received a $\$ 2.00$ fee upon completion of the survey based on the average length of time respondents take to complete the survey. No marketing was necessary using this panel approach, because the panel vendor, MTurk, and TurkPrime administered the survey and identified and recruited eligible respondents. In that sense, the survey respondents selfselected as a convenience sample. Internet protocol ("IP") addresses were used to safeguard against duplicate/multiple responses per IP address. Survey respondents accessed the survey instrument online through MTurk. That survey is described in the Instrument section (infra, p. 39); note that survey respondents were not identified by name and their IP addresses were destroyed once the data gathering process had ended and the analytical process had begun. The survey respondents were obligated only to provide survey responses as to their attitudes about the local police along with minimal demographic data (age, race, ethnicity, gender - the precise demographic questions/items are shown in the complete survey instrument attached as Appendix A) to allow the quantitative groupings desired in the final analysis. Each respondent identified their residence zip code and those self-reported locations were cross-checked against the location information encoded in each respondent's IP address.

Given that all survey respondents were selected from an online panel fitting the demographic requirements (African-American and adult), the researcher preselected the number of respondents needed and the survey went live on MTurk and TurkPrime until that pre-selected survey respondent threshold was met. In that way, inadequate or 


\section{CONFIDENCE IN LAW ENFORCEMENT}

problematic response rates were avoided entirely. Thus, the Qualtrics-based survey was administered through MTurk to ensure a sufficient sample size (approximately 500 total respondents) to optimize the probability that the inquiry would yield a statistically significant sample size based upon significance statistics, literature regarding adequate sample size for exploratory factor analysis, and the Kaiser-Olson-Meyer statistic for Exploratory Factor Analysis sample adequacy.

On balance then, this research used an Internet survey panel approach through MTurk and TurkPrime with survey panel respondents pre-qualified as African-American and adult.

\section{Instrument}

Each civilian survey respondent was invited to complete the survey online (the entire Qualtrics-hosted survey instrument and informed consent advisory are presented in Appendix A). The survey was designed to quantify the respondents' attitudes about their local law enforcement officers and agencies. Each survey item addressed local officers to capture all confidence factors at the officer level.

The survey instrument was designed to capture respondents" "confidence" in local law enforcement as recommended in recent literature (Antrobus, et al., 2015; Bouranta, et al., 2015; Cao, 2011, 2015; Garcia \& Cao, 2005; Hinds, 2009; Jefferis, et al., 2011; Lai \& Zhao, 2010; Tankebe, 2010, 2013; Zhao, et al., 2015). Indeed, the survey selected was taken largely from Cambridge scholar Justice Tankebe's work measuring the impact of police corruption in Ghana on the public's confidence in law enforcement (Tankebe, 2010). Tankebe's work (based on the earlier work of Sunshine \& Tyler, 2003) was underscored by a more recent study determining that among the three measures 


\section{CONFIDENCE IN LAW ENFORCEMENT}

classically used to assess public perceptions of law enforcement (confidence, trust, and satisfaction), confidence (the measure used by Tankebe, 2010) was the superior measure for assessing overall public attitudes toward law enforcement (Cao, 2015). Johnson, Maguire, and Kuhns (2014) found the Tankebe (2010, 2013) public confidence construct to be well-supported, although it differed from Sunshine and Tyler (2003) in some respects. Tankebe grouped his survey questions into three overarching concepts related to public assessments of the police (Cronbach's alpha for the internal consistency of each concept indicated parenthetically) (Cronbach, 1951): (1) trustworthiness of the police ( $\alpha$ $=.80),(2)$ procedural justice meted out by the police $(\alpha=.88)$, and (3) effectiveness of the police $(\alpha=.86)$.

The survey herein is also analogous to the succinct Perceptions of the Police ("POPS") survey utilized by Nadal and Davidoff (2015) in their police perception study. Nadal and Davidoff (2015) used the POPS 12-item Likert (1932) survey format:

1. Police officers are friendly

2. Police officers protect me

3. Police officers treat all people fairly

4. I like the police

5. The police are good people

6. The police do not discriminate

7. The police provide safety

8. The police are helpful

9. The police are trustworthy

10. The police are reliable 


\section{CONFIDENCE IN LAW ENFORCEMENT}

\section{Police officers are unbiased}

12. Police officers care about my concerns

Those researchers surveyed 300 respondents using the 12 Likert items then conducted two principal components analyses with Varimax rotation on two randomly selected split samples of approximately 150 respondents each to identify the components that accounted for the most variation in the responses. The researchers were concerned that the items queried such similar concepts that multicollinearity issues would obscure the mechanism and model, so they used the principal components analyses to aggregate the original twelve questions into a smaller group of components (calculated from exclusive subsets of the twelve questions) that accounted for a high proportion of the variance. In both split samples, Nadal and Davidoff's (2015) principal components analyses revealed that just two components, (1) general attitudes toward the police (questions 1-2, 4-5, 710, and 12) and (2) perceptions of police bias (questions 3, 6, and 11) accounted for from $65-70 \%$ of the variance (p. 5). Nadal, Davidoff, Allicock, Serpe, and Erazo (2017) later applied the POPS survey approach in a mixed methods study related to racial profiling en route to verifying earlier work finding that minorities have statistically poorer perceptions of the police and tying that to adverse personal contacts with the police.

The instant researcher's 37-item survey instrument is presented in Appendix A. That survey included over two dozen separate items (variables) through which the researcher quantified civilian attitudes toward the local police. Critically important in the design phase, it was noted that researchers have found that "general questions on satisfaction with police . . tend to be unstandardized, inconsistent, and at times, have poor choice of wording on questions and response categories, making comparisons across 


\section{CONFIDENCE IN LAW ENFORCEMENT}

time and place impossible (Maslov, 2015)." To address that, the survey in this study has been revised from Tankebe's base to include several generic survey questions (such as "do you trust the police," "do you have confidence in the police," and "do you like the police") (Romain \& Hassell, 2014). Additionally, the survey varies from Tankebe's original by adding several more specific survey questions to capture each respondent's input regarding the following factors or characteristics that myriad researchers have determined to be relevant to civilian confidence in police: respondents' fear of crime or history of victimization (Kusow, Wilson, \& Martin, 1997); respondents' perceptions of neighborhood quality of life (Reisig \& Parks, 2002); respondents' recent police contacts and whether those were self- or police-initiated contacts, and whether those contacts were positive or negative (Wu, Sun, \& Triplett, 2009); and respondents' sense of neighborhood context, disorder, distress, and disadvantage (Lord, Kuhns, \& Friday, 2009; Wolfe, et al., 2016; Wu, Sun, \& Triplett, 2009). Unlike some studies and surveys, such as the PoliceCommunity Interaction Survey and Rosenbaum, Escamilla, Enciso, Christoff, and Hartnett (n.d.), which surveyed only those who had personal contact with law enforcement, the instant survey captures confidence of all respondents and treats contact as an independent variable that may interact significantly with other factors in generating or affecting confidence in law enforcement. Note that all items in the instant survey, aside from demographic, independent variable questions, are queried in Likert fashion with three response options: Disagree (coded as 1), Neither Disagree nor Agree (coded as 2), and Agree (coded as 3). The researcher deemed it unnecessary and perhaps misleading to include additional response options (such as, 5-part or 7-part Likert categories), because any potentially discriminating value of the additional response categories would be 


\section{CONFIDENCE IN LAW ENFORCEMENT}

overwhelmed by respondent differences in defining the more finely parsed extra

categories (what exactly is the difference between strongly disagree and disagree as it were). But there is clear discriminating power as between response options agree and disagree.

Setting up a priori factors as a starting point, pre-survey, the 37 survey items were preliminarily aggregated as presented here:

Table 4. Mapping the Survey Questions/Items and a priori Factors

Demographics (excluded from the factor analysis) indicate your age range in years Indicate your sex Indicate your predominate race Indicate whether you are Hispanic Please type your residence zip code

Neighborhood Context Variables (treated as an additive variable, not a factor) Crime level in my neighborhood has recently improved

Crime in my neighborhood is rare I feel safe walking my neighborhood at night My neighborhood is a secure place to live

Contact with Local Enforcement Variables (treated as an additive variable) I have had recent contact with local officers

That recent contact was positive/negative

Generic Civilian Perceptions

Racial makeup of officers/community consistent

I have confidence in local officers

I trust the local officers

I am satisfied with the local officers

A priori Satisfaction/Effectiveness Component

I am proud of the local officers

Local officers treat everyone with respect

Local officers treat everyone with dignity

Local officers account for needs and concerns of people

Local officers sincerely try to help people

Local officers try to find best solutions

Local officers respond promptly to crimes

Local officers always provide victim assistance

Local officers always provide assistance needed

Local officers are doing well in controlling violent crime

Local officers are doing a good job in my neighborhood 


\title{
CONFIDENCE IN LAW ENFORCEMENT
}

\author{
A priori Confidence Component \\ Local officers are trustworthy \\ Local officers are often dishonest \\ Local officers are usually honest \\ Local officers always act within the law \\ Local officers treat everyone equally \\ Local officers respect people's rights \\ Local officers follow through on their decisions and promises \\ Local officers always act within the law \\ Local officers clearly explain reasons for actions \\ Local officers provide opportunity to correct unfair decisions \\ Local officers use fair rules and procedures \\ Local officers handle vehicle and person stops well
}

\section{Procedures}

After completion of the initial literature review and finalization of the survey instrument, the research proceeded in a stepwise fashion as detailed in this section. First, the researcher gathered the extant data from the Governing (2015) and Governing Data (2015) analysis of the LEMAS (2013) breakdown by community of full-time sworn officer racial/ethnic profiles, and the researcher gathered the Census (2010) and Census (2013) total population data and percent by racial/ethnic category per city, matching the categories in the Governing (2015) study. The researcher then computed the Racial Mirror Index for African-Americans (RMI-AA) for each community in the Governing (2015) study.

RMI-AA $=\frac{\text { Percent of Sworn Officers who are African-American }}{-} * 100$

Instructive, Rastogi, Johnson, Hoettel, and Drewerym (2011) developed arrays of number and percent of African-Americans per city and Reaves (2011) developed arrays of cities by number of sworn law enforcement personnel.

Following that RMI-AA calculation process, the researcher used statistical power and effect size calculations to compute a statistically significant sample size $(n)$ for the 


\section{CONFIDENCE IN LAW ENFORCEMENT}

population of African-American adults in the United States (Cohen, 1988). The researcher also considered scholarly statistical works related to exploratory factor analysis and determined that $n=300$ was sufficient to have adequate confidence in the factors generated in those steps where the shared communalities were strong, the factors are empirically interpretable, and the ratio of $n$ to number of factors is at least four or higher (MacCallum, Widaman, Preacher, \& Hong, 2001; Mundform, Shaw, \& Ke, 2005, p. 166; Pearson \& Mundform, 2010, p. 366; Tabatchnick \& Fidell, 1983, p. 379). Many studies approve of a much smaller $n$, as low as 100: "our results show that if communalities are high, recovery of population factors in sample data is normally very good, almost regardless of sample size, level of overdetermination, or the presence of model error" (MacCallum, Widaman, Preacher, \& Hong, 2001, p. 636).

Next, the researcher purchased the requisite number of qualifying respondents from Amazon Mechanical Turk ("MTurk") to optimize the likelihood that an adequate sample size was obtained populated by eligible respondents only: African-American adults. The online tool, TurkPrime, was used to dovetail with MTurk to qualify only African-American adults to complete the survey. MTurk and TurkPrime collaborated to market the survey to MTurk participants such that only African-American adults were offered the opportunity to complete the survey but potential respondents and actual respondents were never informed by the researcher, MTurk, or TurkPrime that only African-American adults were being surveyed. The researcher hosted the survey on Qualtrics but used MTurk and TurkPrime to market the survey opportunity to AfricanAmerican adult respondents only.

Prior to marketing the survey through MTurk and TurkPrime, the researcher 


\section{CONFIDENCE IN LAW ENFORCEMENT}

developed an instruction sheet, informed consent notice, waiver form, and additional information concerning the study and respondent voluntariness and confidentiality. All were drafted consistent with Nova Southeastern University's Institutional Review Board and the Abraham S. Fischler College of Education and School of Criminal Justice. The researcher also used Qualtrics online assessment tools to verify that the survey was readable and clear. The Qualtrics-hosted survey then was designed with an interface to preclude prospective respondents from accessing and responding to the survey until they had read and understood all those notices and digitally signed (confidentially using their MTurk vendor identifications) all necessary waivers. Researcher contact information for questions was conspicuously presented on the face of the survey notices to facilitate respondent questions and follow-up at the respondents' sole option. Each survey response was coded by Internet Protocol ("IP”) address (from which latitude and longitude of respondent's computing device could be decoded) to ensure that respondents accurately self-reported their residence locations via zip code (which was used to identify the law enforcement agency serving each respondent's community).

Prior to administering the survey, the researcher obtained approval, indeed a waiver, from the Nova Southeastern University Institutional Review Board (dated February 10, 2019). After IRB approval, the survey was then posted to MTurk and TurkPrime using the survey hosted on Qualtrics. Given that the survey required just fiveto-ten minutes to complete (in addition to the pre- and post-instructions sections), the payment for a completed survey was set at $\$ 2.00$ per respondent, somewhat in excess of the MTurk rule-of-thumb ten cents per minute MTurk cost per respondent.

After IRB approval, the researcher shared the survey with the members of the 


\section{CONFIDENCE IN LAW ENFORCEMENT}

Dissertation Committee for any input or amendments they may recommend prior to administration of the survey. In this step, after modifying the survey given the Committee members' recommendations, the researcher then pre-tested the survey to a limited set of MTurk respondents to ensure clarity, functionality, and ease of use for respondents. That pre-test step, processed through Qualtrics, MTurk, and TurkPrime, released the survey to a limited number of MTurk respondents (the eventual count was 67) on February 16, 2019. The pre-test was intended to identify unexpected and undesirable flaws in the survey design so that the survey could be repaired prior to full rollout of the final survey. Pre-test responses indicated several concerns with the original survey design: (1) in two instances, multiple responses were received from a single IP address indicating that coresidents or fellow household members or friends used the same computing device to complete the survey; (2) the unique identifier used to ensure full completion of the survey had to be redesigned for better reliability and understandability by MTurk respondents; and (3) the number of Likert options (five, ranging from strongly disagree to strongly agree) was reduced (to three, for respondent ease and upon recommendation of both Qualtrics and MTurk personnel and online tools). Beyond those few modifications, no other changes were deemed necessary before full rollout of the final survey. The pre-test respondents' surveys were discarded and were not included in the final data, computations, or conclusions herein.

On February 21-23, 2019, totaling just 48 hours, the online survey was shared with pre-qualified MTurk survey panel members. The TurkPrime platform ensured that only African-American adults were offered the survey and thus only African-American adults could complete the survey. The researcher set $n=500$ to ensure that after data 


\section{CONFIDENCE IN LAW ENFORCEMENT}

cleaning the remaining qualified and completed surveys would exceed the $n=300$ exploratory factor analysis threshold. The researcher also set two other parameters to ensure qualified MTurk respondents. The two parameters required that each MTurk survey panel member permitted to take the survey had at least 50 prior MTurk survey completions and that each had at least a $95 \%$ prior survey acceptance rate (the rate at which their prior survey responses had been deemed acceptable by the survey researcher). Both those thresholds were recommended in the Amazon Mechanical Turk Requester Guide (Amazon Web Services, 2017). MTurk and TurkPrime, which were administering the researcher's Qualtrics survey, hit the 500 adult African-American respondent threshold in just 48 hours.

As MTurk and TurkPrime were administering the surveys, the individual respondent survey responses were captured by Qualtrics. The researcher had no direct contact with any of the MTurk respondents before they completed the survey; all interaction with the MTurk respondents was conducted by MTurk and TurkPrime, including paying each MTurk respondent the agreed-upon $\$ 2.00$ payment to each survey respondent upon successful completion of each survey. Once all surveys were completed, the researcher reviewed the individual respondent survey answers to search for any invalid survey responses. The researcher then exported the respondents' survey answers from Qualtrics into SPSS-25.

Within SPSS-25, the researcher cleaned the data by removing (A) the nonAfrican-American respondents (just 5 out of 500); (B) respondents with more than six missing responses (just 5 out of 495); (C) respondents where Hispanic status was not identified (just one); and (D) respondents where sex/gender was not listed (just one). 


\section{CONFIDENCE IN LAW ENFORCEMENT}

In step twelve, the researcher extracted the longitude and latitude data from the respondents' IP addresses, converted those to zip code, city, county, and standard metropolitan area using online data translators (OpenDataSoft, n.d.; CD Light, L.L.C., 2019; Dotsquare, L.L.C., 2019), and then compared those IP-derived zip codes to the zip code each respondent had identified within the survey as the respondent's residence zip code. Where the latitude and longitude for a survey respondent (derived from the IP address) substantively diverged from the respondent-reported zip code, that respondent's entire survey response was omitted (there were only five respondents excluded for this reason). After taking this verification step, and as the informed consent notice notified the respondents, each respondent's residence zip code was retained in the database but each respondent's IP address was purged to ensure respondent confidentiality.

The researcher then added the RMI-AA data as a new variable in the SPSS-25 database for each respondent from the LEMAS data. Although the LEMAS 2013 survey was completed by law enforcement agencies across the country, the law enforcement agencies serving many cities in which the MTurk respondents lived had not submitted a LEMAS survey for 2013. For the respondents' cities that did not submit a LEMAS 2013 survey, the researcher was therefore unable to compute RMI-AA for those cities because the racial makeup of those agencies' sworn officers could not be determined. For that reason, the 138 respondents whose cities' law enforcement agencies had not submitted a LEMAS 2013 survey were removed from the database. After the data cleaning, 356 MTurk respondents remained in the database for analysis, still above the accepted $n=300$ threshold for exploratory factor analysis. 


\section{CONFIDENCE IN LAW ENFORCEMENT}

\section{Data Analysis}

The analysis moved in stepwise fashion. Using SPSS-25, the researcher queried the data along the following dimensions and in the following order.

First, the researcher identified the descriptive statistics (mean, median, standard deviation, range) for each of the individual items regarding civilian confidence in the police (survey items 5-37), globally for all respondents, and by age, and by gender, looking for patterns in the data.

Second, the researcher graphed those individual items to visually identify kurtosis, skewness, bimodality, and the like.

Third, addressing RQ1, the researcher conducted exploratory factor analysis to explore whether the a priori components for satisfaction and confidence aligned with the components after data gathering. In this step, the researcher used the computed factors to calculate a "master confidence" value or aggregate "confidence in the police" and then calculated the descriptive statistics (mean, median, standard deviation, range) for each; the researcher also applied bivariate correlation methods to quantify the correlation between this computed "master confidence" value and the single pure confidence, pure satisfaction, and pure trust items (are you confident in the local officers, are you satisfied with the local officers, and do you trust the local officers). Individual items injecting substantial multicollinearity into the "master confidence" level did not appear after the factors were generated through the factor analysis step. In the factor analysis step, the computed factors were significant (Cronbach's $\alpha=.76-.89)[\alpha>.7$ required (Nunnallly, 1978)] and the factors together accounted for $86 \%$ of the variance $(p<.001)$.

Fourth, addressing RQ2, the researcher plotted in scattergram fashion the "master 


\section{CONFIDENCE IN LAW ENFORCEMENT}

confidence" variable against pure confidence, pure satisfaction, and pure trust values, in turn, and for all respondents.

Fifth, addressing RQ3, the researcher scatterplotted RMI-AA against each of the civilian general categories in turn: "master confidence," pure confidence, pure satisfaction, and pure trust.

Sixth, addressing RQ4, the researcher applied ordinal logistic regression to evaluate the relative impacts of RMI-AA, recent contacts with law enforcement, fear of crime, and neighborhood context on African-American confidence in local law enforcement.

Seventh, the researcher then mined the resulting data and statistics for findings, insights, concepts, and conclusions resulting from the study. Thereafter, the researcher proffered answers to the study's research questions:

RQ1: Using Exploratory Factor Analysis, which factors most efficiently summarize the variation in the measured variables (the survey responses) related to African-American civilian confidence in local law enforcement.

RQ2: Are the factors derived in the Exploratory Factor Analysis for research question 1 strongly associated with African-American civilian (a) confidence, (b) satisfaction, and (c) trust in local law enforcement.

RQ3: Do African-Americans living in communities served by law enforcement agencies wherein African-Americans are underrepresented among sworn officers in those agencies have lower confidence in those local law enforcement agencies.

RQ4: When African-American underrepresentation among sworn officers in local law enforcement is modeled with other variables known to correlate with civilian 


\section{CONFIDENCE IN LAW ENFORCEMENT}

confidence in law enforcement (including neighborhood context, fear of crime, recent adverse police contact), is underrepresentation still - or does it become - a significant predictor of African-American civilian confidence in local law enforcement.

Finally, the researcher used the findings to derive managerial and administrative decision-making and policy-setting recommendations for pathways law enforcement agencies could use when applying these data and findings in their jurisdictions. 


\section{Chapter 4}

\section{Results}

\section{Participant Geography}

After data cleaning, 356 qualifying respondents' surveys remained. Those 356 respondents reside in 36 of the 50 states plus the District of Columbia (Alabama, Arizona, Arkansas, California, Colorado, Connecticut, Delaware, Florida, Georgia, Illinois, Indiana, Kentucky, Louisiana, Maryland, Massachusetts, Michigan, Minnesota, Mississippi, Missouri, Nevada, New Hampshire, New Jersey, New York, North Carolina, Ohio, Oklahoma, Oregon, Pennsylvania, South Carolina, South Dakota, Tennessee, Texas, Utah, Virginia, Vermont, Washington State, and Washington D.C.). The included states comprise 32 of the 34 states with the highest Black populations and contain $98 \%$ of the Black population in the United States (Black Demographics, 2019a).

The geographic locations of the 356 survey respondents is illustrated here:

Figure 4: RMI-AA for All Study Agencies - Circle Diameter Reflects RMI-AA

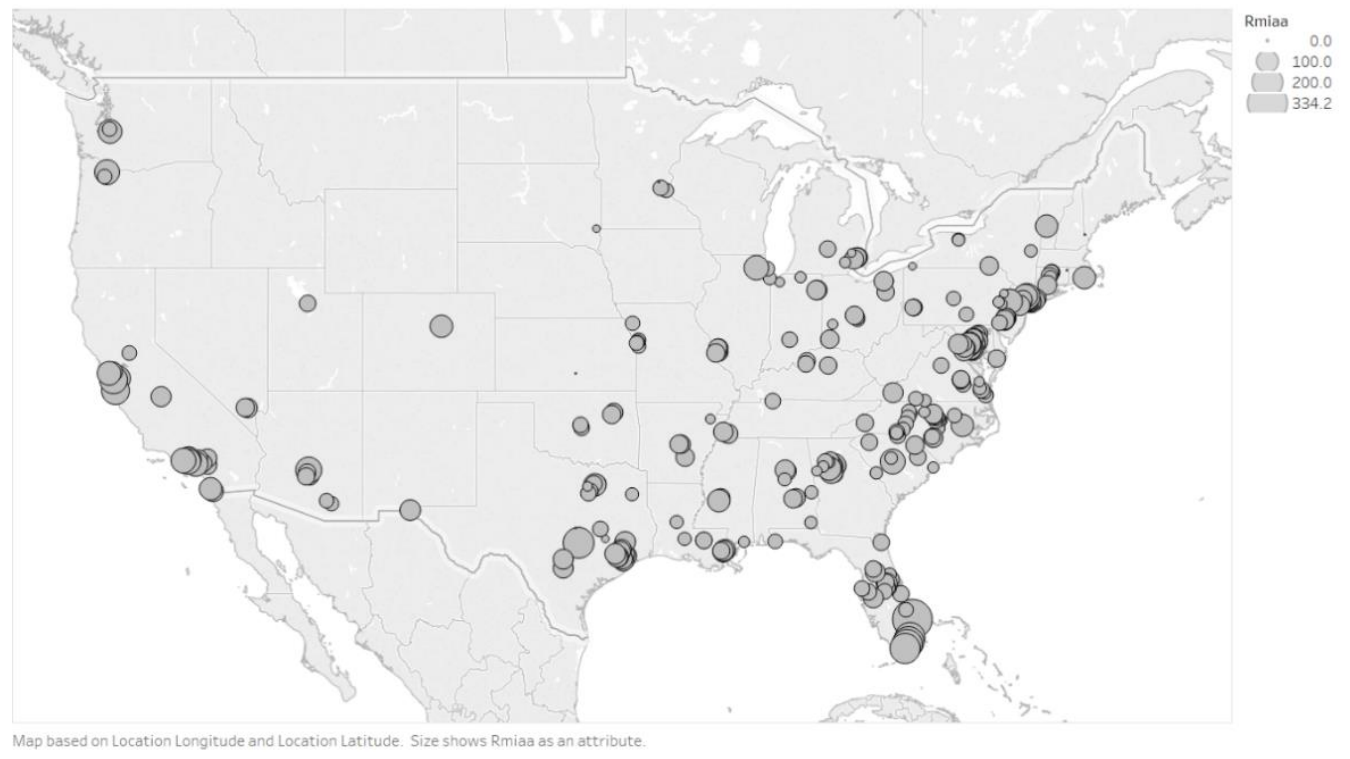




\section{CONFIDENCE IN LAW ENFORCEMENT}

The 356 respondents are served by 199 different law enforcement agencies with total number of full-time sworn officers per agency ranging from $8-34,454(\bar{x}=3,299)$ and those 199 agencies serve civilian populations ranging from 5,144-9,962,789 $(\bar{x}=$ $1,000,809)$.

Figure 5: Full-time Sworn Officers per Agency in Study

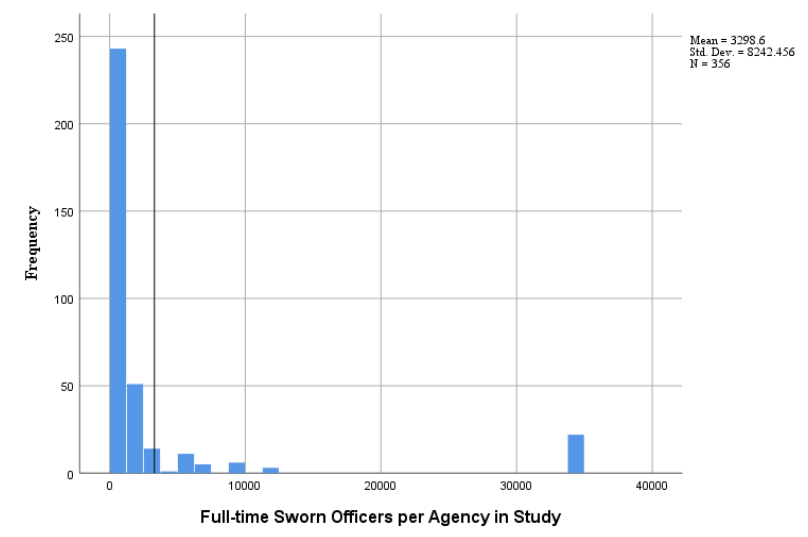

Figure 6: Civilian Population Served per Agency in Study

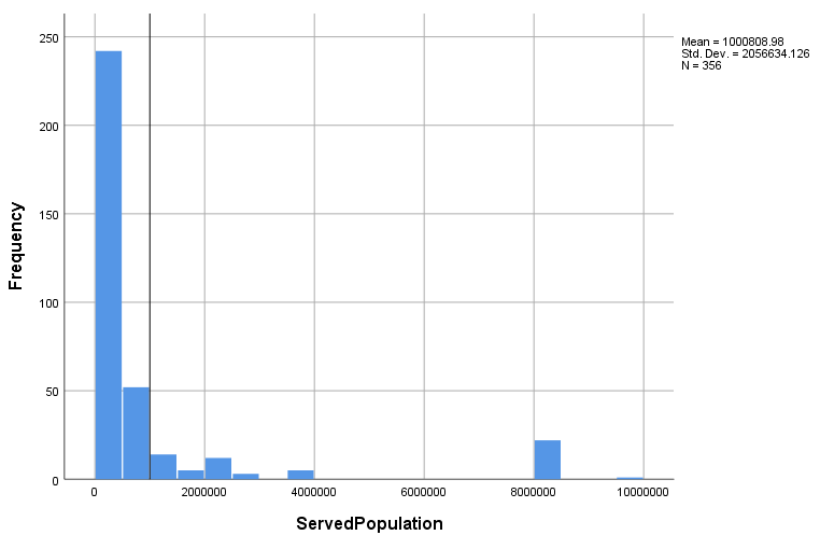

\section{Racial Mirror Index}

The Racial Mirror Index-African-American ("RMI-AA") for the study agencies ranged from 0-334 ( $\bar{x}=66.1)$, graphically presented below: 
Figure 7: Racial Mirror Index-African-American for Cities in Study

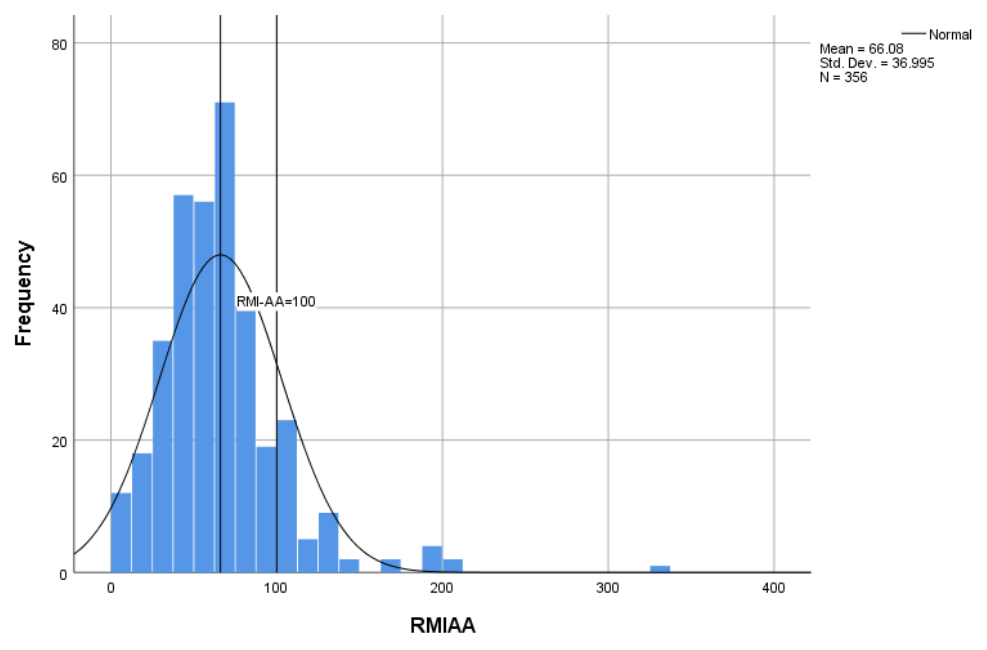

Of the 356 respondents, $87 \%$ lived in areas served by agencies with RMI-AA less than $100,70 \%$ with RMI-AA less than $75,34 \%$ with RMI-AA less than 50 , and $8 \%$ with RMI-AA less than 25. Consistent with earlier assessments of RMI-AA across American law enforcement agencies (Governing, 2015), this RMI-AA graph of the study agencies reveals a strong right (positive) skew (+1.9075). Geographically, the national pattern of low, medium, and high RMI-AA is presented in the following maps:

Figure 8: RMI-AA for Study Agencies - Agencies with RMI-AA $<51$

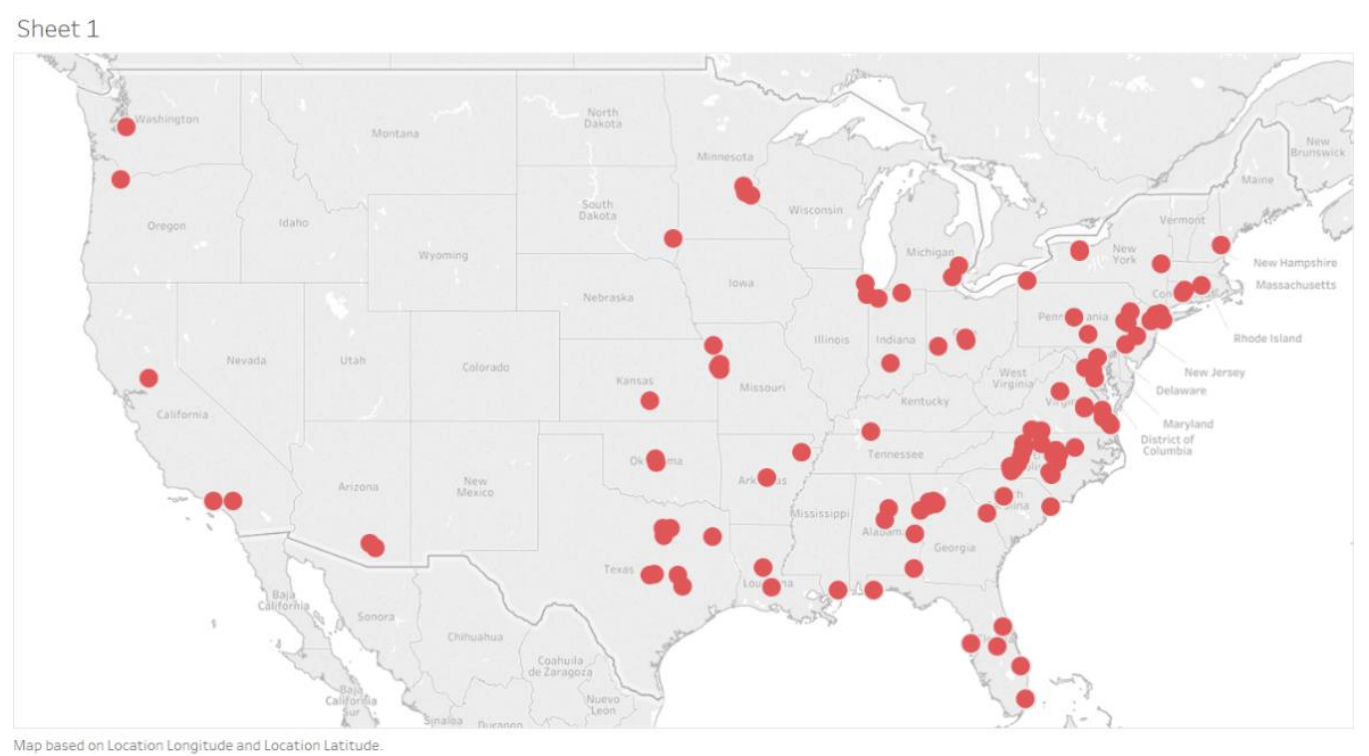




\section{CONFIDENCE IN LAW ENFORCEMENT}

Figure 9: RMI-AA for Study Agencies - Agencies with RMI-AA = 51-75

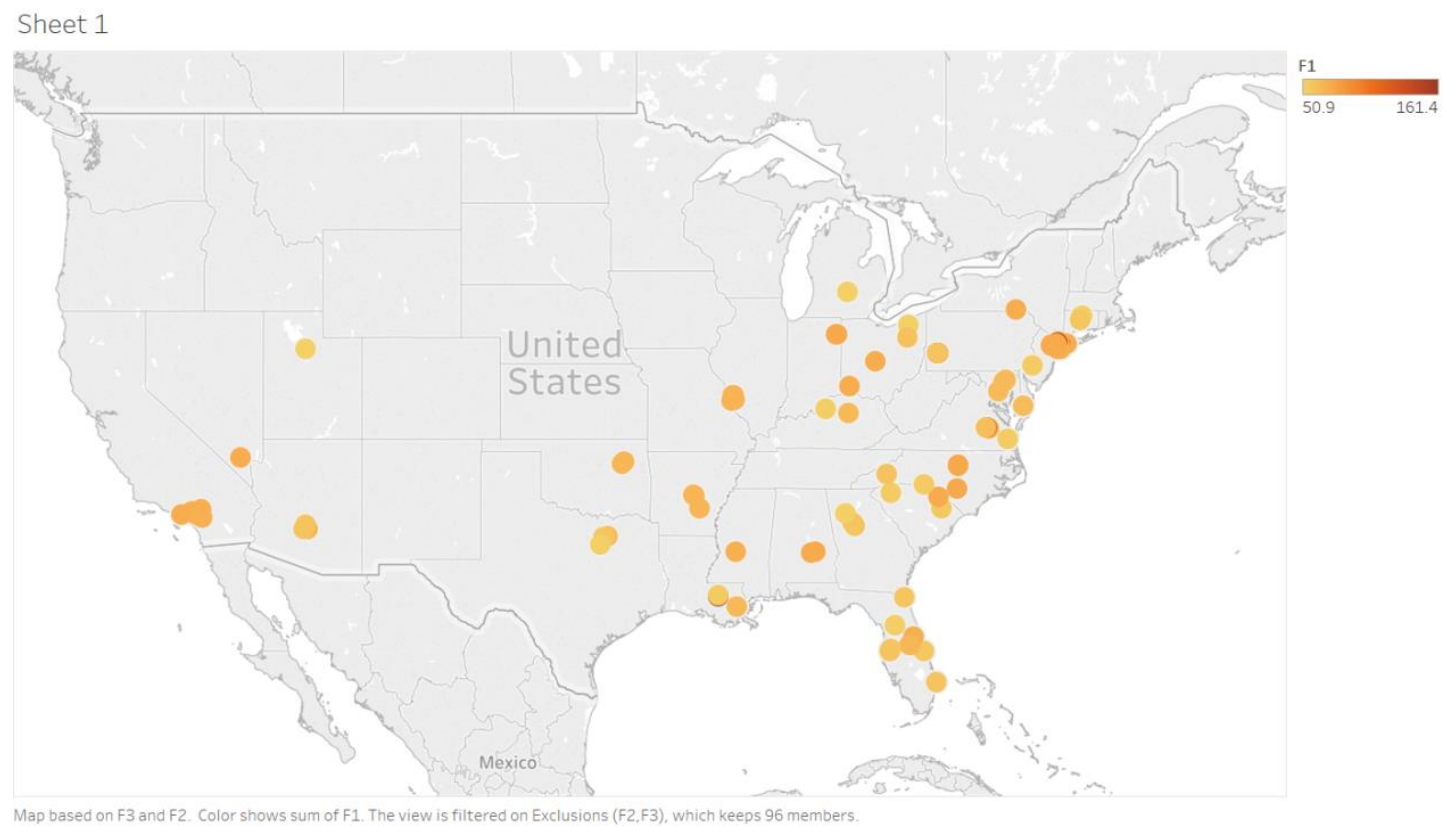

Figure 10: RMI-AA for Study Agencies - Agencies with RMI-AA = 76-100

Sheet 1

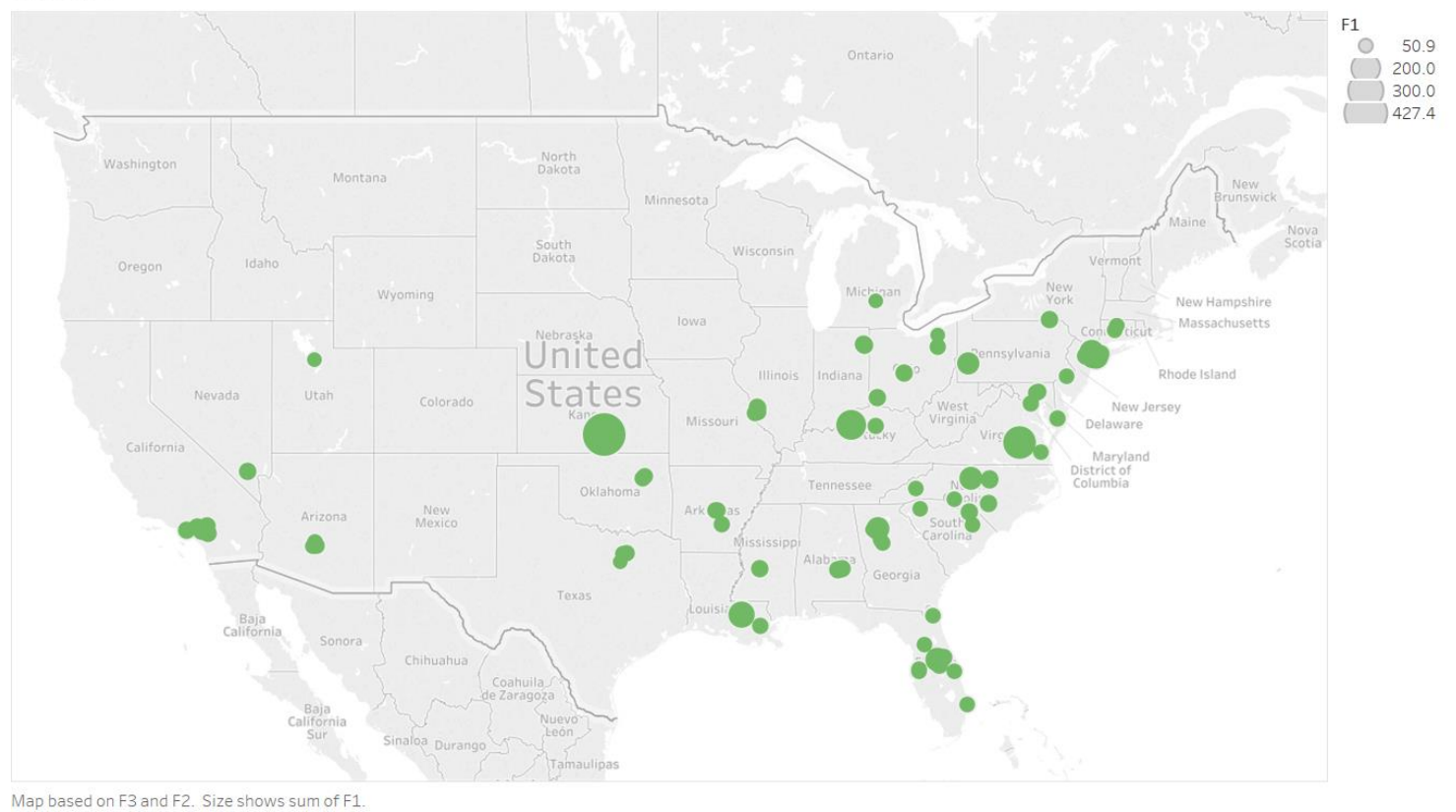




\section{CONFIDENCE IN LAW ENFORCEMENT}

Figure 11: RMI-AA for Study Agencies - Agencies with RMI-AA > 100

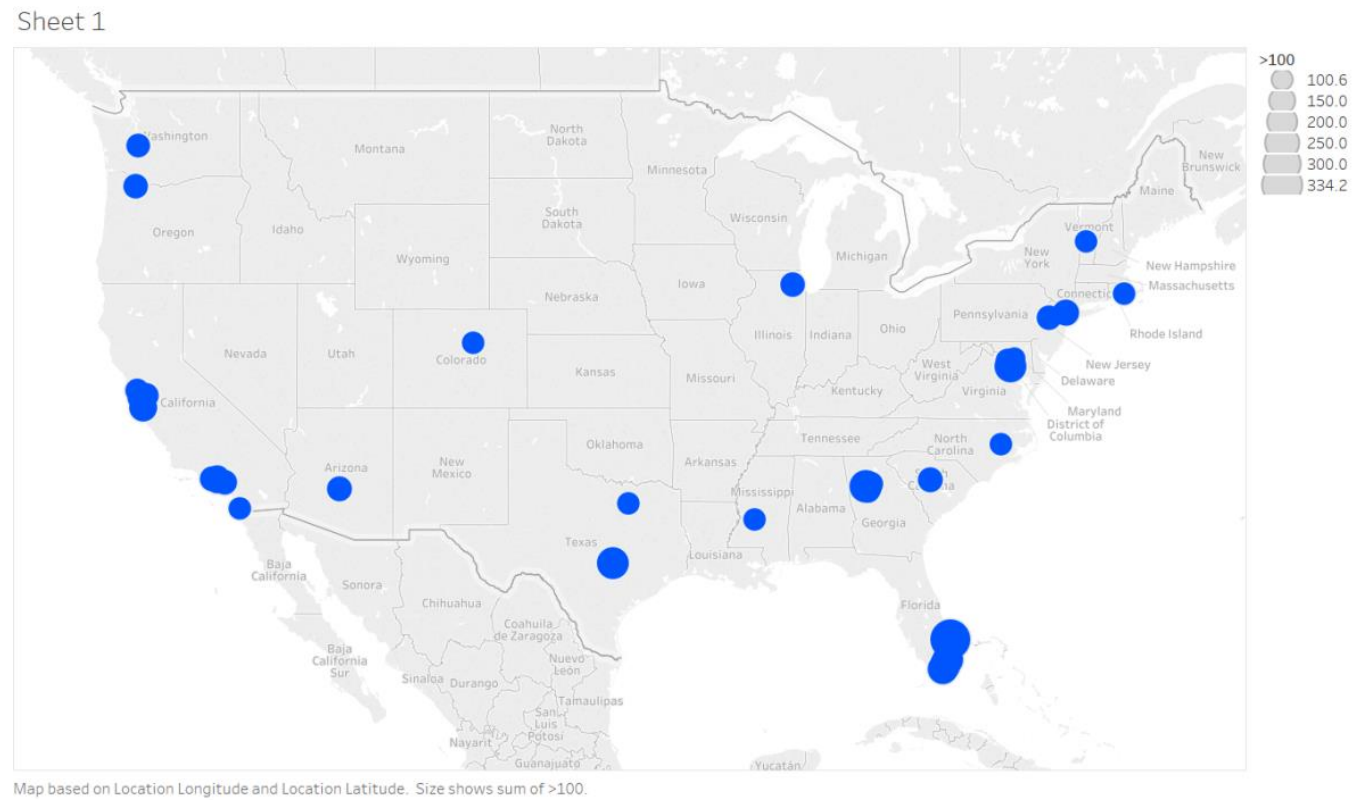

\section{Participants}

As explained in the Methodology section, the researcher used Amazon

Mechanical Turk ("MTurk") and TurkPrime tools to ensure that all participants were African-American adults residing in the United States as required by the procedures employed and research questions posed. The 356 qualified participants' characteristics are presented in the following table:

\section{Table 5. Participant Characteristics}

\begin{tabular}{lc}
\hline Characteristic & Rounded for Convenience \\
\hline Sex/Gender & Male $(40 \%) ;$ Female $(60 \%)$ \\
Age Range & $18-29$ years $(34 \%) ; 30-49$ years $(53 \%) ; 50+$ years $(13 \%)$ \\
Hispanic & Yes $(4 \%) ;$ No $(95 \%) ;$ Withheld $(1 \%)$ \\
\hline
\end{tabular}

As required by the study, all participants were adult African-Americans. The participant characteristics varied from the characteristics of the total African-American population in the United States, as follows: male (48\%), female (52\%); 18-29 years (46.5\%), 30-49 years (27.7\%), 50+ years (25.8\%); Hispanic (2.5\%) (Black Demographics, 2019b); 


\section{CONFIDENCE IN LAW ENFORCEMENT}

Census 2010). Thus, the participants were more female, older, and somewhat more Hispanic than the total African-American population in the United States.

\section{Exploratory Factor Analysis}

The researcher conducted exploratory factor analysis ("EFA") to determine the degree to which the thirty-plus individual survey items could be reduced to a set of latent, internally cohesive, and inter-correlated factors. The initial EFA modeling runs were conducted for all 356 respondents and for the following subset of 21 survey items (extraction communalities, identifying the approximate variance in each variable accounted for by the factors in the model, are presented in parentheses):

The officers in my community are usually honest (.507)

The officers in my community usually act within the law (.460)

The officers in my community treat everyone with respect (.782)

The officers in my community treat everyone with dignity (.799)

The officers in my community treat everyone equally (.683)

The officers in my community respect people's right (.750)

The officers in my community follow through on their commitments $(.523)$

The officers in my community always act within the law (.564)

The officers in my community take account of the needs of those they serve $(.604)$

The officers in my community sincerely try to help (.619)

The officers in my community clearly explain reasons for their actions (.515)

The officers in my community provide opportunities to correct their errors (.521)

The officers in my community use rules and procedures that are fair (.645) 


\section{CONFIDENCE IN LAW ENFORCEMENT}

The officers in my community respond promptly to violent crimes (.466)

The officers in my community are always ready to assist victims (.569)

The officers in my community are always ready to help others (.563)

The officers in my community are doing well in controlling crime (.544)

The officers in my community are doing a good job overall (.663)

There are not many instances of crime in my neighborhood (.251)

I feel safe walking in my neighborhood at night (.448)

My neighborhood is a good place to live (.836)

The officers in my community usually handle their duties well (.528)

The item with the lowest extraction communalities ("There are not many instances of crime in my neighborhood.") was removed from the EFA model runs thereafter. During the EFA, it was immediately apparent that the sample size of 356 was clearly sufficient (Kaiser-Meyer-Olkin [“KMO”] Measure of Sampling Adequacy = .950; Bartlett's ChiSquare Test of Sphericity $=5007, d f=231, p<.000)$. As rules of thumb, $n>300$ and $n>10 *$ number of variables are adequate samples and yield good EFA results (Mahmoud \& Kamel, 2010, p. 1884). The researcher conducted the EFA in SPSS-25 using no rotation, orthogonal (Varimax) rotation, and oblique (Oblimin) rotation, sequentially. The nonrotated results are presented first.

The non-rotated model, using the Kaiser Criterion (preserving only those factors with Eigenvalues exceeding 1.0) coalesced the 21 remaining variables into three factors, together explaining $58.37 \%$ of the variance. Consistent with practice, in selecting the optimum number of factors in EFA, two other tests were applied to the factors: (1) scree plot assessment and (2) parallel analysis, which calculates a master matrix of randomly 


\section{CONFIDENCE IN LAW ENFORCEMENT}

generated correlation matrices to determine the number of factors where the modelcomputed Eigenvalues exceed those that were randomly selected.

The scree plot for the unrotated model is presented below. Note that the deflection point appears at just two factors rather than three and the third and subsequent factors in the unrotated model are rubble (that is, scree) at the base of inflection point of the Eigenvalue curve. Using the scree plot approach, the unrotated model favors selecting just two factors.

Figure 12: Scree Plot of Unrotated Factor Analysis Assessing Kaiser Criterion

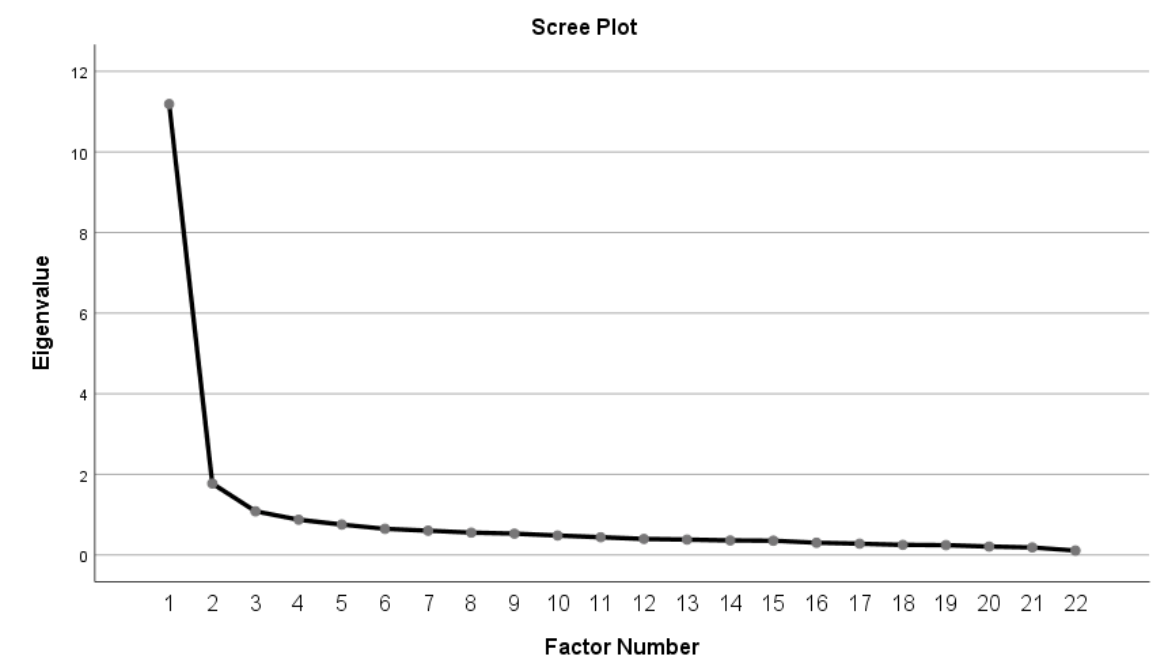

Using Gonzaga’s online Parallel Analysis Engine (Gonzaga University, 2019)

with 21 variables, sample size of 356, and 100 randomly generated correlation matrices, again the two-factor solution appears to be superior. For Factor 1, the model-computed value, 11.189, far exceeds the random master value of 1.460, so Factor 1 should be retained. For Factor 2, the model-computed value, 1.772, exceeds the random master value of 1.380, so Factor 2 should be retained. But for Factor 3, the model-computed value, 1.082, does not exceed the random master value of 1.318, so Factor 3 does not outperform random results and Factor 3 should not be retained using the Parallel Analysis 


\section{CONFIDENCE IN LAW ENFORCEMENT}

Engine approach. Having reviewed the factor results using the Kaiser Criterion, scree plot, and Parallel Analysis Engine, the researcher concluded that a two-factor model was superior.

The unrotated EFA model was rerun forcing a two-factor solution and departing from the Kaiser Criterion. The results appear below (note that insignificant loadings under $.40-$ are omitted):

Figure 13. Factor Loadings on Two-Factor Solution - Unrotated

Usually Honest

Usually Acts Within Law

Treats Everyone With Respect

Treats Everyone With Dignity

Treats Everyone Equally

Respects Peoples Rights

Follows Through on Promises

Always Acts Within the Law

Takes Account of Needs of Others

Sincerely Tries To Help

Clearly Explains Reasons for Actions

Provides Opportunities to Correct Errors

Rules and Procedures are Fair

Responds Promptly

Always Ready to Provide for Victims

Always Able to Provide Assistance

Doing Well Controlling Violent Crime

Doing a Good Job Overall

Not Many Instances of Crime in my Neighborhood

I Feel Safe Walking at Night in my Neighborhood

My Neighborhood is a Good Place to Live

The Officers Usually Handle Calls Well

\begin{tabular}{c}
\multicolumn{2}{c}{ Factor } \\
\hline $1 \quad 2$ \\
\hline 0.711
\end{tabular}

0.669

0.836

0.845

0.759

0.840

0.724

0.732

0.765

0.776

0.706

0.719

0.771

0.619

0.731

0.733

0.644

0.751

0.441

0.517

$0.440 \quad 0.748$

0.690

Extraction Method: Principal Axis Factoring.

a. 2 factors extracted. 14 iterations required. 


\section{CONFIDENCE IN LAW ENFORCEMENT}

In this unrotated factor solution, there are minimal cross-loadings of variables on multiple factors. That minimal cross-loading reflects that the variables load separately on the factors and that should make the factors easy to interpret. The two factors load as indicated below:

Figure 14. Factor Interpretation for Unrotated Model

\begin{tabular}{lll} 
& \multicolumn{2}{c}{ Factor } \\
\cline { 2 - 3 } & 1 & 2 \\
\cline { 2 - 2 } Usually Honest & 0.711 & \\
Usually Acts Within Law & 0.669 \\
Treats Everyone With Respect & 0.836 \\
Treats Everyone With Dignity & 0.845 \\
Treats Everyone Equally & 0.759 \\
Respects Peoples Rights & 0.840 \\
Follows Through on Promises & 0.724 \\
Always Acts Within the Law & 0.732 \\
Takes Account of Needs of Others & 0.765 \\
Sincerely Tries To Help & 0.776 \\
Clearly Explains Reasons for Actions & 0.706 \\
Provides Opportunities to Correct Errors & 0.719 \\
Rules and Procedures are Fair & 0.771 & \\
Responds Promptly & 0.619 & \\
Always Ready to Provide for Victims & 0.731 & \\
Always Able to Provide Assistance & 0.733 & \\
Doing Well Controlling Violent Crime & 0.644 & \\
Doing a Good Job Overall & 0.751 & \\
\hline Not Many Instances of Crime in my Neighborhood & & 0.441 \\
I Feel Safe Walking at Night in my Neighborhood & & 0.517 \\
My Neighborhood is a Good Place to Live & 0.440 \\
\hline The Officers Usually Handle Calls Well & 0.748 \\
\hline
\end{tabular}

Assessing the factor loadings pattern above, one can discern rather clear interpretations for each factor. Factor 1 could be interpreted to capture "Procedural Justice and Effectiveness" while Factor 2 appears to be capturing "Neighborhood Context." Both of those factor interpretations are consistent with findings in the literature that confidence in 


\section{CONFIDENCE IN LAW ENFORCEMENT}

local law enforcement is affected by procedural justice, neighborhood contexts, fear of crime, recent adverse police contacts, race, age, and police effectiveness (see literature review for references). However, most studies identify Procedural Justice and Police Effectiveness as separate factors and not as monolithic. Therefore, the factor analysis was run again eliminating the Neighborhood Context items to see whether the resulting factors would separately capture the Procedural Justice and Police Effectiveness variables in different factors.

When the Neighborhood Context variables were removed and the factor analysis rerun, the unrotated factor matrix (using the Kaiser Criterion of Eigenvalues over 1.00) revealed substantial cross-loading so Varimax (orthogonal) and Promax (non-orthogonal) rotation methods were applied with Promax yielding the following Promax-rotated factor analysis results:

Figure 15. Promax-rotated Factor Matrix without Neighborhood Context Variables

\begin{tabular}{lcc}
\hline & \multicolumn{2}{c}{ Factor } \\
\cline { 2 - 3 } & \multicolumn{1}{c}{1} & 2 \\
\hline Usually Honest & 0.410 \\
Usually Act Within the Law & & 0.438 \\
Treats Everyone With Respect & 0.912 & \\
Treats Everyone With Dignity & 0.918 & \\
Treats Everyone Equally & 0.917 & \\
Respects Peoples' Rights & 0.815 & \\
Follows Through on Promises & 0.479 & \\
Always Acts Within the Law & 0.678 & \\
Takes Account of Needs of Civilians & 0.494 & \\
Sincerely Tries to Help & 0.440 & \\
Clearly Explains Reasons for Acts & 0.554 & \\
Provides Opportunities to Correct Errors & 0.528 & \\
Rules and Procedures are Fair & 0.788 & \\
\hline Responds Promptly & & 0.714 \\
Always Ready to Provide for Victims & & 0.609 \\
Always Able to Provide Assistance & & 0.581 \\
\hline
\end{tabular}




\section{CONFIDENCE IN LAW ENFORCEMENT}

\section{Doing Well in Controlling Violent Crime \\ Doing a Good Job Overall \\ Usually Handle Situations Well

Extraction Method: Principal Axis Factoring.

Rotation Method: Promax with Kaiser Normalization.

a. Rotation converged in 3 iterations.

As predicted, once the neighborhood context variables were removed from the process of specifying the factors, Procedural Justice (Factor 1) and Police Effectiveness (Factor 2) loaded on separate factors. Cumulatively, those two factors account for $59.528 \%$ of the variance in the constituent variables.

Rotation methods are applied to factor analysis when the initial unrotated factors have substantial cross-loadings making interpretation difficult to accomplish. Here, the model including neighborhood context variables had very little cross-loading so required no rotation for interpretation, but the model omitting those Neighborhood Context variables had enough cross-loading that interpretation required rotation. Nonetheless, rotated or unrotated factor analyses do not change the factors upon which each variable loads; rotation enhances interpretation only. The Promax-rotated factor solution was retained for interpretation.

\section{Confirmatory Factor Analysis and Reliability Estimation}

Following EFA, the resulting two-factor model without Neighborhood Context variables was evaluated using Confirmatory Factor Analysis ("CFA") to measure the reliability of the factors. Cronbach's (1951) alpha $(\alpha)$ is a measure of internal consistency or reliability; $\alpha>.7$ is typically acceptable in CFA for social science research (Nunnally, 1978). 


\section{CONFIDENCE IN LAW ENFORCEMENT}

Factor 1 (Cronbach's $\alpha=.948$ ) captures the twelve key Procedural Justice concepts from the survey items: law enforcement honesty, courtesy, respect, fairness, respect, sincerity, and rules and procedures that yield equitable and just law enforcement actions.

Factor 2 (Cronbach's $\alpha=.888$ ) coalesces the seven survey items focused on Police Effectiveness ( similar to the retrospective "Satisfaction" concept identified above): law enforcement acts within the law, responds promptly, is always able to assist, handles situations well, and is doing a good job controlling crime.

Through the factor analysis process, the model generated scores for each participant on each factor. Those scores were then used as independent variables for the two factors, along with additive scores for neighborhood context, a variable for recent adverse police contact, demographic variables (age, sex, Hispanic ethnicity), and, of course, the Racial Mirror Index-African American ("RMI-AA") for each participant.

\section{Associational Analyses - Dependent and Independent Variables}

Preliminary to specifying regression models to assess the drivers of AfricanAmerican confidence, satisfaction, and trust in local law enforcement, correlations and chi-square tests were applied to the independent and dependent variables:

Dependent variables:

CONFIDENCE: I have confidence in the officers who serve my community $(1=$ disagree; $2=$ neutral; $3=$ agree $)$ [ordinal]

TRUST: I trust the law enforcement officers who serve my community (1 $=$ disagree $; 2$ = neutral; 3 = agree) [ordinal]

SATISFACTION: I am satisfied with the law enforcement officers serving my community $(1=$ disagree; $2=$ neutral; $3=$ agree $)$ [ordinal] 


\section{CONFIDENCE IN LAW ENFORCEMENT}

Independent variables:

RMI-AA: index of African-American underrepresentation on local police force compared to proportion in population served [scale]

PROCEDURAL JUSTICE: Factor 1 from Promax-rotated factor analysis [scale]

POLICE EFFECTIVENESS: Factor 2 from Promax-rotated factor analysis [scale]

NEIGHBORHOOD CONTEXT (sum of not much crime in my community, my neighborhood is a good place to live for security, and I feel safe walking at night in my neighborhood) [ordinal]

POLICE CONTACT (professional police contact in past year was $1=$ negative $; 2=$ neutral; $3=$ positive) [ordinal]

AGE GROUP (1=18-29 years; $2=30-49$ years; $3=50+$ years $)$ [ordinal]

SEX (1=male; $2=$ female; $3=$ other or withheld $)$ [nominal]

HISPANIC (1=Hispanic; 2=not Hispanic; 3=withheld) [nominal]

For the ordinal versus ordinal crosstabulation assessments, Somers' delta

(Somers' $d$ ), Kendall's tau-b $\left(\tau_{b}\right)$, and Speakman's rank-order correlation (rho or $\rho$ ) were used, nonparametric measures of the strength and direction of the association between two ordinal variables. Based on Somers' $d$, Kendall's tau-b, and Spearman's rank-order correlation, rho:

1. Adverse Police Contact [ordinal] was significantly correlated with Confidence [ordinal] $\left(d=.195, p=.000 ; \tau_{b}=.199, p=.000 ; \rho=.216 ; p=.000\right)$; Trust $(d=.231$, 


\section{CONFIDENCE IN LAW ENFORCEMENT}

$\left.p=.000 ; \tau_{b}=.237, p=.000 ; \rho=.254 ; p=.000\right) ;$ and Satisfaction $((d=.237, p=.000$

$\left.\tau_{b}=.242, p=.000 ; \rho=.260 ; p=.000\right)$.

2. Neighborhood Context [ordinal] was significantly correlated with Confidence [ordinal] $\left(d=.254, p=.000 ; \tau_{b}=.255, p=.000 ; \rho=.300 ; p=.000\right) ;$ Trust $(d=.293$, $\left.p=.000 ; \tau_{b}=.294, p=.000 ; \rho=.351 ; p=.000\right) ;$ and Satisfaction $((d=.312, p=.000$; $\left.\tau_{b}=.314, p=.000 ; \rho=.371 ; p=.000\right)$.

To assess associations between ordinal and nominal/dichotomous variables, lambda $(\lambda)$ and gamma $(\gamma)$, asymmetrical and symmetrical measures, respectively, and chi-square $\left(\chi^{2}\right.$, linear-by-linear association) measures were applied. Based on lambda, gamma, and chi-square (linear-by-linear) measures:

3. Age Group [nominal/ordinal] is significantly associated with Confidence [ordinal] $\left(\lambda=.054, p=.001 ; \gamma=.241, \mathrm{p}=.002 ; \chi^{2}=11.807, \mathrm{p}=.001\right) ;$ and Trust $(\lambda=.052, p=.002 ;$ $\left.\gamma=.174, p=.028 ; \chi^{2}=6.807, p=.009\right)$; but is not significantly associated with Satisfaction, except based on chi-square assumptions $(\lambda=.027, p=.401 ; \gamma=.150$, $\left.\mathrm{p}=.056 ; \chi^{2}=5.001, \mathrm{p}=.025\right)$.

4. Sex [nominal] is not significantly associated with Confidence [ordinal] $(\lambda=.003$, $\left.p=.317 ; \gamma=.126, p=.154 ; \chi^{2}=2.115, p=.146\right)$; not significantly associated with Trust $\left(\lambda=.011, p=.753 ; \gamma=.149, p=.092 ; \chi^{2}=2.983, p=.084\right)$; and is not significantly associated with Satisfaction, except based on chi-square assumptions $(\lambda=.011$, $\left.p=.695 ; \gamma=.195, p=.029 ; \chi^{2}=4.951, p=.026\right)$.

5. Hispanic [nominal] is not significantly associated with Confidence [ordinal] $\left(\lambda=.004, p=.564 ; \gamma=.175, \mathrm{p}=.300 ; \chi^{2}=0.709, \mathrm{p}=.400\right) ;$ not significantly associated with Trust $\left(\lambda=.013, p=.082 ; \gamma=.149, p=.092 ; \chi^{2}=2.697, p=.101\right)$; and not 


\section{CONFIDENCE IN LAW ENFORCEMENT}

significantly associated with Satisfaction $(\lambda=.032, p=.051 ; \gamma=.322, \mathrm{p}=.063$;

$\left.\chi^{2}=1.928, \mathrm{p}=.165\right)$

To assess associations between scale (interval) and ordinal data, Spearman's rankorder correlation $(r h o, \rho)$ is applied. Based on Spearman's rho:

6. Procedural Justice [scale/interval], the scores on Factor 1 in the Promax-rotated two-factor analysis, is significantly associated with Confidence [ordinal] ( $\rho=.767$; $p=.000)$; Trust $(\rho=.741 ; p=.000)$; and Satisfaction $(\rho=.753 ; p=.000)$.

7. Police Effectiveness [scale/interval], the scores on Factor 2 in the Promax-rotated two-factor analysis, is significantly associated with Confidence [ordinal] $(\rho=.746$; $p=.000)$; Trust $(\rho=.760 ; p=.000)$; and Satisfaction $(\rho=.815 ; p=.000)$.

8. RMI-AA [scale/interval], Racial Mirror Index-African American, a measure of underrepresentation of African-Americans on the local police force, is not significantly associated with Confidence [ordinal] $(\rho=-.043 ; p=.425)$; Trust $(\rho=$ -.035; $p=.481)$; and Satisfaction $(\rho=-.207 ; p=.609)$.

That lack of significant association between RMI-AA and Confidence, Trust, and Satisfaction indicates that whether African-Americans are underrepresented, overrepresented, or equivalently represented on the local force and the degree or that underrepresentation are not significantly associated with the degree to which AfricanAmericans have confidence, trust, or satisfaction in local law enforcement. That finding bears additional attention.

First, the correlations among the key ordinal categories (confidence, trust, and satisfaction) shows that they are highly correlated - but not identical - measures of civilian attitudes toward the police: 
CONFIDENCE IN LAW ENFORCEMENT

Figure 16. Parametric Correlations Among Confidence, Trust, and Satisfaction

\begin{tabular}{llccc}
\hline & & CONFIDENCE & TRUST & SATISFIED \\
\hline CONFIDENCE & Pearson Correlation & 1 & $.720^{* *}$ & $.709^{* *}$ \\
& Sig. (2-tailed) & & .000 & .000 \\
& $\mathrm{~N}$ & 355 & 351 & 352 \\
\hline \multirow{2}{*}{ TRUST } & Pearson Correlation & $.720^{* *}$ & 1 & $.746^{* *}$ \\
& Sig. (2-tailed) & .000 & & .000 \\
& $\mathrm{~N}$ & 351 & 352 & 351 \\
\hline \multirow{2}{*}{ SATISFIED } & Pearson Correlation & $.709^{* *}$ & $.746^{* *}$ & 1 \\
& Sig. (2-tailed) & .000 & .000 & \\
& $\mathrm{~N}$ & 352 & 351 & 353 \\
\hline
\end{tabular}

**. Correlation is significant at the 0.01 level (2-tailed).

Figure 17. Nonparametric Correlations Among Confidence, Trust, and Satisfaction

\begin{tabular}{|c|c|c|c|c|c|}
\hline & & & CONFIDENCE & TRUST & SATISFIED \\
\hline \multirow{12}{*}{$\begin{array}{l}\text { Kendall's } \\
\text { tau_b }\end{array}$} & CONFIDENCE & Correlation & 1.000 & $.679^{* *}$ & $.666^{* *}$ \\
\hline & & Coefficient & & & \\
\hline & & Sig. (2-tailed) & . & .000 & .000 \\
\hline & & $\mathrm{N}$ & 355 & 351 & 352 \\
\hline & TRUST & Correlation & $.679^{* *}$ & 1.000 & $.705^{* *}$ \\
\hline & & Coefficient & & & \\
\hline & & Sig. (2-tailed) & .000 & . & .000 \\
\hline & & $\mathrm{N}$ & 351 & 352 & 351 \\
\hline & SATISFIED & Correlation & $.666^{* *}$ & $.705^{* *}$ & 1.000 \\
\hline & & Coefficient & & & \\
\hline & & Sig. (2-tailed) & .000 & .000 & . \\
\hline & & $\mathrm{N}$ & 352 & 351 & 353 \\
\hline \multirow{8}{*}{$\begin{array}{l}\text { Spearman's } \\
\text { rho }\end{array}$} & CONFIDENCE & Correlation & 1.000 & $.723^{* *}$ & $.710^{* *}$ \\
\hline & & Coefficient & & & \\
\hline & & Sig. (2-tailed) & . & .000 & .000 \\
\hline & & $\mathrm{N}$ & 355 & 351 & 352 \\
\hline & TRUST & Correlation & $.723^{* *}$ & 1.000 & $.747^{* *}$ \\
\hline & & Coefficient & & & \\
\hline & & Sig. (2-tailed) & .000 & . & .000 \\
\hline & & $\mathrm{N}$ & 351 & 352 & 351 \\
\hline
\end{tabular}


CONFIDENCE IN LAW ENFORCEMENT

\begin{tabular}{llccc} 
SATISFIED & Correlation & $.710^{* *}$ & $.747^{* *}$ & 1.000 \\
& Coefficient & & & \\
& Sig. (2-tailed) & .000 & .000 &. \\
& $\mathrm{~N}$ & 352 & 351 & 353 \\
\hline
\end{tabular}

**. Correlation is significant at the 0.01 level (2-tailed).

Thus, Confidence is significantly, strongly, and positively correlated with Trust $(r=.720$, $p=.000 ; \tau_{b}=.679, p=.000 ; \rho=.723 ; p=.000$ ) (Pearson, 1895); Confidence is significantly, strongly, and positively correlated with Satisfaction $\left(r=.709, p=.000 ; \tau_{b}=.666, p=.000\right.$; $\rho=.710 ; p=.000$ ); and Trust is significantly, strongly, and positively correlated with Satisfaction $\left(r=.746, p=.000 ; \tau_{b}=.705, p=.000 ; \rho=.747 ; p=.000\right)$.

Second, the participants' perceptions of underrepresentation appear to be largely accurate. The correlation between the RMI-AA in each respondent's community and each respondent's response to the representativeness survey item (\#1: "The racial makeup of the officers serving my community is consistent with the racial makeup of the people in my community") is significant at the .05 significance level regardless of statistics applied but insignificant at the .001 significance level for each statistic $\left(r=.115, p=.030 ; \tau_{b}=.126\right.$, $p=.002 ; \rho=.162 ; p=.002)$. And graphically, the relationship between RMI-AA and confidence, trust, and satisfaction, respectively, betrays substantial lack of association: 
Figure 18. Histogram for RMI by Low Confidence (on a common x-scale)

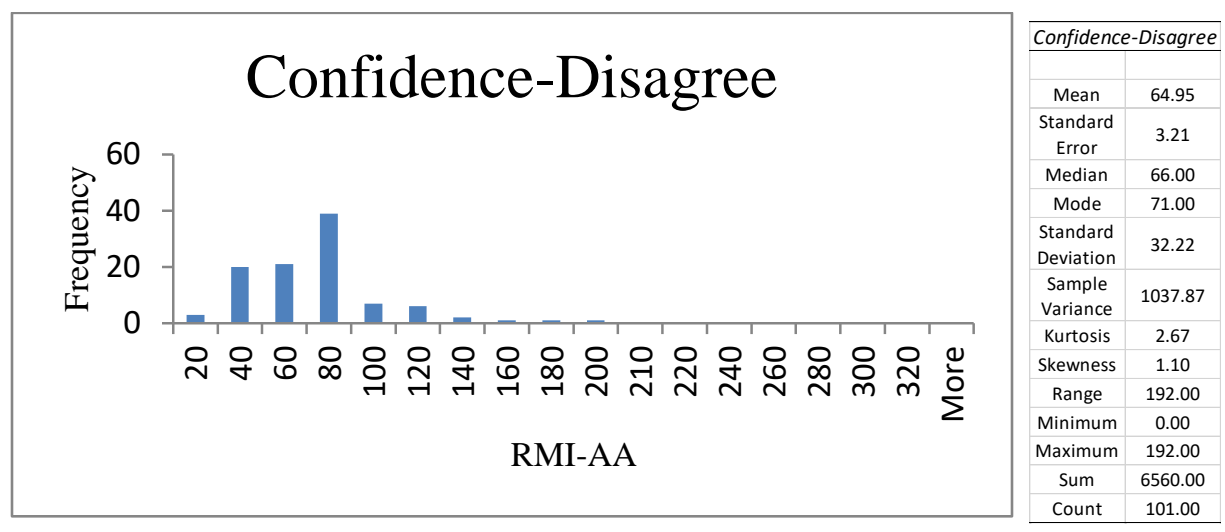

Figure 19. Histogram for RMI by Neutral Confidence (common x-scale)

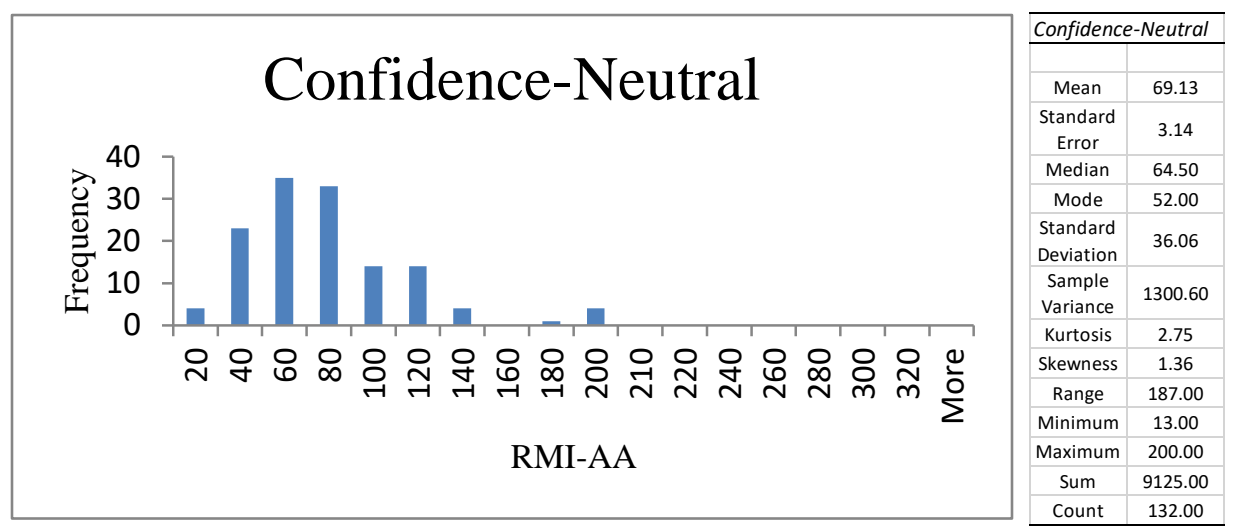

Figure 20. Histogram for RMI by High Confidence (on a common x-scale)

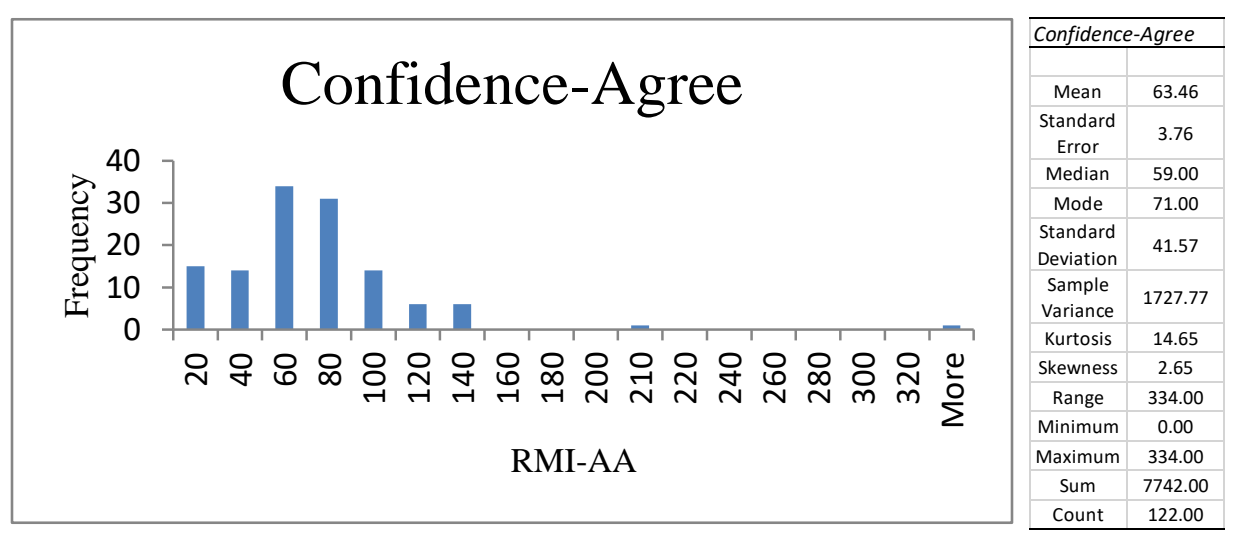




\section{CONFIDENCE IN LAW ENFORCEMENT}

Figure 21. Histogram for RMI by Low Trust (on a common $x$-scale)

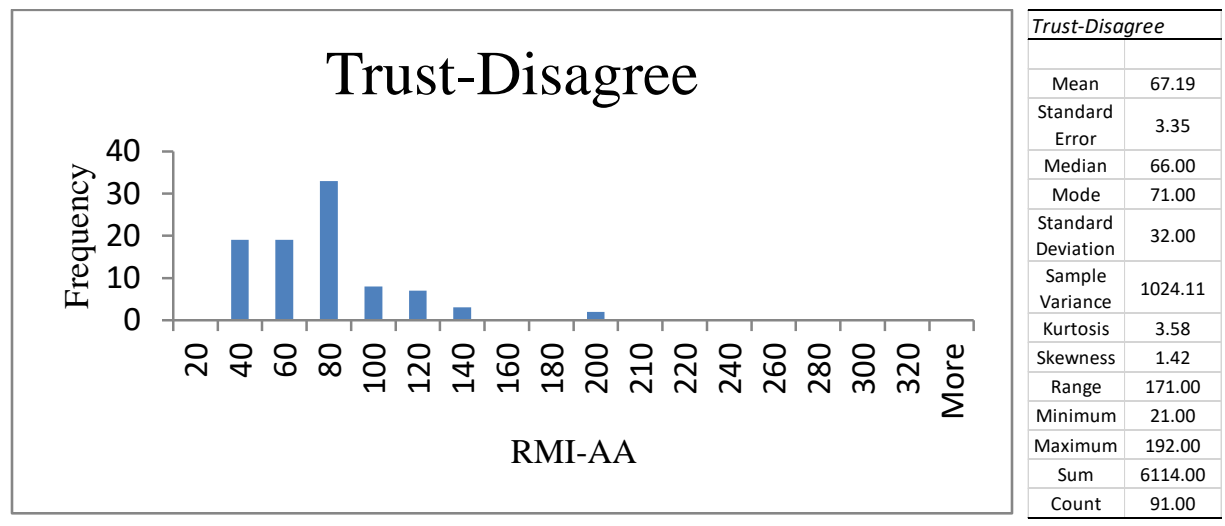

Figure 22. Histogram for RMI by Neutral Trust (on a common $x$-scale)

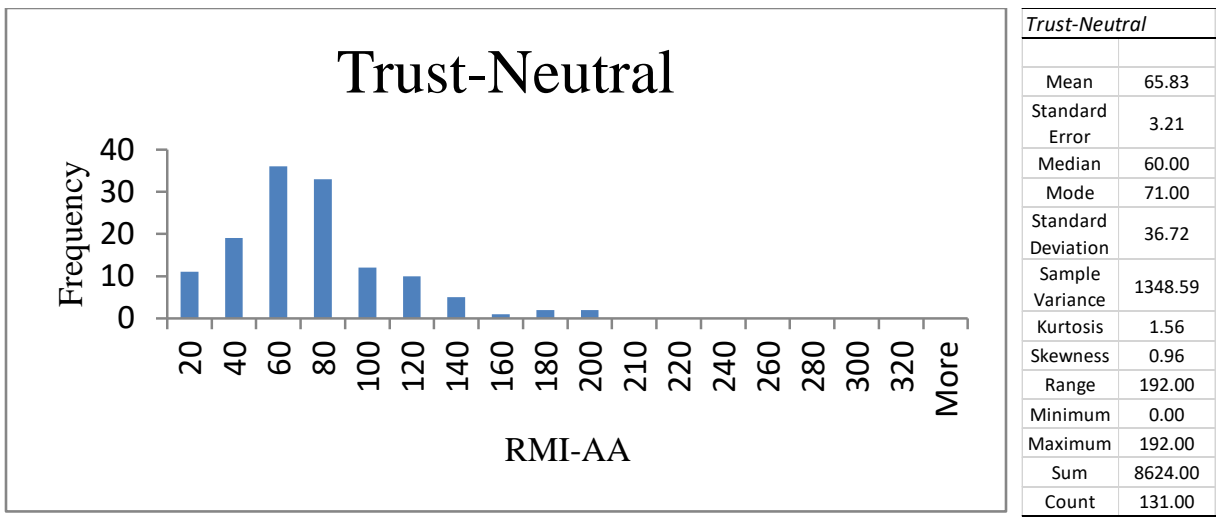

Figure 23. Histogram for RMI by High Confidence (on a common x-scale)

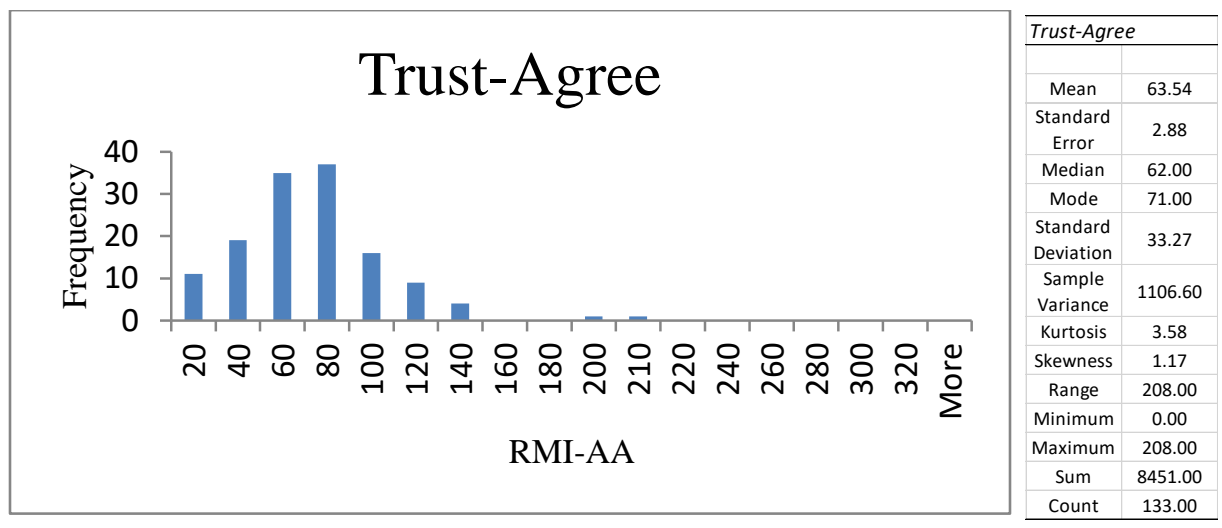


Figure 24. Histogram for RMI by Low Satisfaction (on a common x-scale)

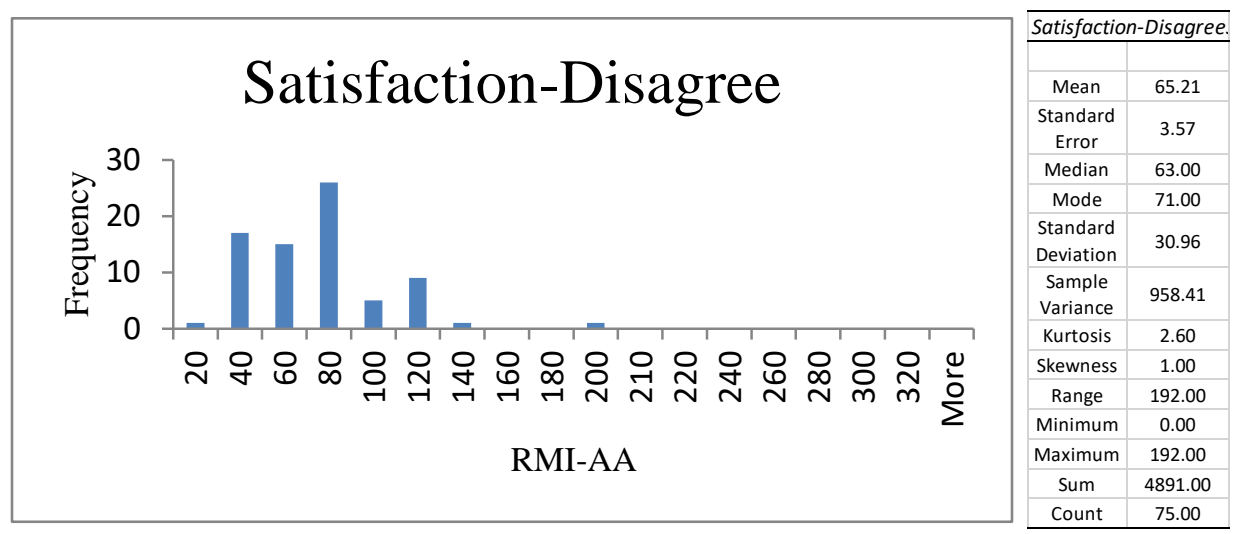

Figure 25. Histogram for RMI by Neutral Satisfaction (common $x$-scale)

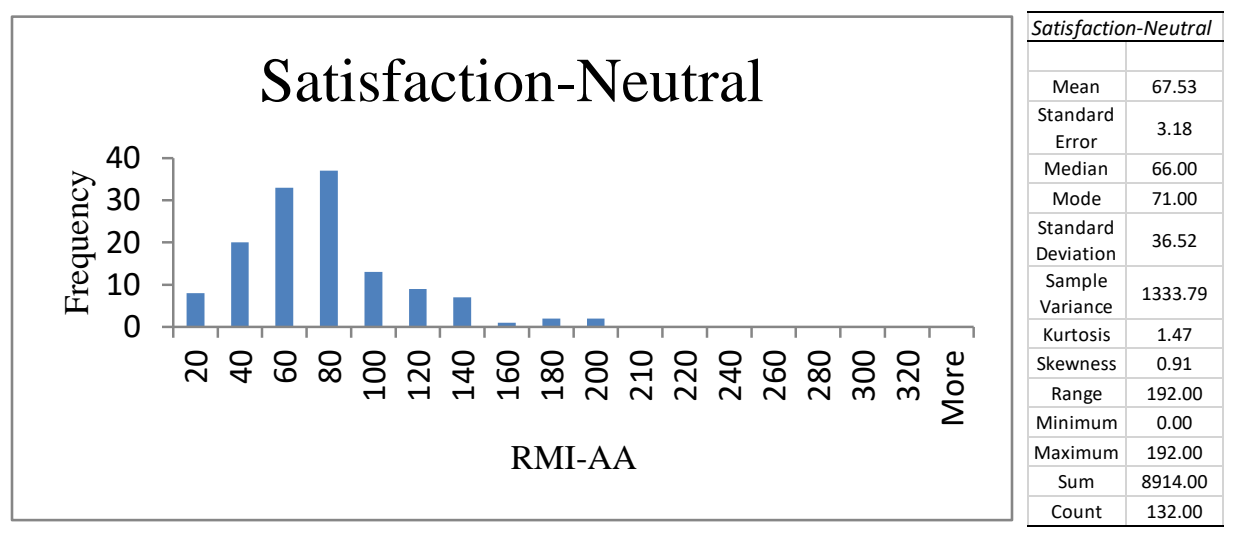

Figure 26. Histogram for RMI by High Satisfaction (on a common x-scale)

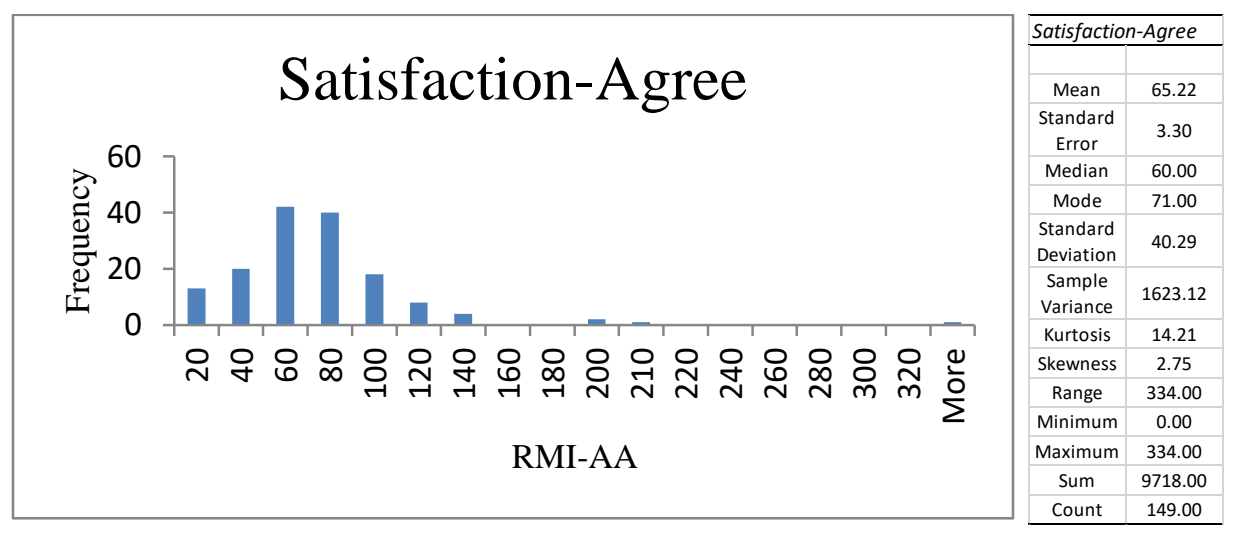




\section{CONFIDENCE IN LAW ENFORCEMENT}

Visual inspection of the nested histograms and descriptive statistics for each concept above verify the statistical results. Almost without regard to the level of RMI-AA, participants at low, neutral, and high Confidence, Trust, and Satisfaction exhibit consistent histograms and the descriptive statistics across the low, neutral, and high subgroups are virtually identical. Thus, the degree of underrepresentation does not appear to be driving different levels of African-American distrust, dissatisfaction, or lack of confidence in local law enforcement.

As a double-check on the lack of apparent association between RMI-AA and Confidence, Trust, and Satisfaction, respectively, RMI-AA was converted into a ranked (ordinal) 13-group variable in SPSS-25. Thereafter, One-Way Nonparametric ANOVA (the Kruskal-Wallis $H$ Test) was applied. Based on Kruskal-Wallis, no significant association was found between ranked RMI-AA and Confidence $(H=.414)$; Trust $(H=.522)$; or Satisfaction $(H=.616)$; thus, no post-hoc tests and no Bonferroni correction were required.

To further illuminate the relationship if any, between RMI-AA (interval/scale data) and Confidence, Trust, and Satisfaction (ordinal data), the investigation turned to Ordinal Logistic Regression.

\section{Ordinal Logistic Regression}

Given the factors identified in the Exploratory Factor Analysis, this investigation then sought to specify an ordinal logistic regression model (several of the independent variables and all of the dependent variables are ordinal measures) to ascertain the impact of the two factors (Procedural Justice and Police Effectiveness), plus neighborhood context, recent adverse police contact, gender, Hispanic status, age category, and RMI- 


\section{CONFIDENCE IN LAW ENFORCEMENT}

AA on African-American satisfaction, trust, and confidence in local law enforcement.

The generic regression model formulations are as follows:

\section{$\underline{\text { Generic Concept Models }}$}

A-A “Confidence" $=f\left\{\right.$ Factor $_{\mathrm{PJ}}$, Factor $_{\mathrm{PE}}, \mathrm{PC}, \mathrm{NC}, \mathrm{RMI}-\mathrm{AA}$, Demographics $\}$

$\mathrm{A}-\mathrm{A}$ “Trust" $=f\left\{\right.$ Factor $_{\mathrm{PJ}}$, Factor $_{\mathrm{PE}}, \mathrm{PC}, \mathrm{NC}, \mathrm{RMI}-\mathrm{AA}$, Demographics $\}$

A-A "Satisfaction" $=f\left\{\right.$ Factor $_{\mathrm{PJ}}$, Factor $_{\mathrm{PE}}, \mathrm{PC}, \mathrm{NC}, \mathrm{RMI}-\mathrm{AA}$, Demographics $\}$

where Factor $_{\mathrm{PJ}}=$ respondents' scores on Factor 1: Procedural Justice;

Factor $_{\mathrm{PE}}=$ respondents' scores on Factor 2; Police Effectiveness;

$\mathrm{PC}=$ whether respondent had recent police-initiated adverse contact;

$\mathrm{NC}=$ neighborhood context (additive variable)

RMI-AA=index of underrepresentation of African-Americans on the local police force serving each respondent; and

Demographics=Age Group, Sex, Hispanic status

The following table highlights some of the key Ordinal Logistic Regression model runs.

Table 6. Ordinal Logistic Regression Model Runs and Key Statistics

\begin{tabular}{|c|c|c|c|c|c|c|c|c|c|c|c|c|}
\hline \multirow[b]{2}{*}{ Model \# } & \multirow[b]{2}{*}{ Dependent Vbl } & \multirow[b]{2}{*}{ Model Fit $p$} & \multirow[b]{2}{*}{ Pseudo $\mathrm{R}^{2}$} & \multirow[b]{2}{*}{ T-P-Lines $p$} & \multicolumn{8}{|c|}{ Variables in the Model Run with Significance of Each Parameter Estimate, $p=$} \\
\hline & & & & & RMI-AA & Factor $_{P J}$ & Factor $_{P E}$ & Police Contact & Neighborhood & Age & Sex & Hispanic \\
\hline 1 & Confidence & 0.677 & 0.001 & 0.216 & 0.675 & & & & & & & \\
\hline 2 & Trust & 0.494 & 0.001 & 0.627 & 0.514 & & & & & & & \\
\hline 3 & Satisfaction & 0.986 & 0.000 & 0.619 & 0.986 & & & & & & & \\
\hline 4 & Confidence & 0.000 & 0.674 & 0.067 & & 0.000 & 0.000 & & & & & \\
\hline 5 & Trust & 0.000 & 0.672 & 0.389 & & 0.000 & 0.000 & & & & & \\
\hline 6 & Satisfaction & 0.000 & 0.743 & 0.312 & & 0.001 & 0.000 & & & & & \\
\hline 7 & Confidence & 0.000 & 0.675 & 0.096 & 0.594 & 0.000 & 0.000 & & & & & \\
\hline 8 & Trust & 0.000 & 0.672 & 0.595 & 0.725 & 0.000 & 0.000 & & & & & \\
\hline 9 & Satisfaction & 0.000 & 0.743 & 0.484 & 0.618 & 0.001 & 0.000 & & & & & \\
\hline 10 & Confidence & 0.000 & 0.697 & 0.810 & 0.779 & 0.000 & 0.000 & $\begin{array}{l}.178-570 \\
\end{array}$ & |.104-.999 & .014-.026 & 0.000 & $.270-610$ \\
\hline 11 & Trust & 0.000 & 0.717 & 0.633 & 0.312 & 0.000 & 0.000 & 等.000-.039. & 列. $033-.546$ & 作 $.002-.032$ & 0.000 & 0.000 \\
\hline 12 & Satisfaction & 0.000 & 0.783 & 0.683 & 0.751 & 0.000 & 0.000 & 等. $001-.016$ & 然- .629 & .176-.620 & 0.000 & $.993-.994$ \\
\hline 13 & Confidence & 0.000 & 0.700 & 0.679 & 0.855 & 0.000 & 0.000 & $\begin{array}{l}.287-.826 \\
\end{array}$ & .095-.951 & $.009-.021$ & 0.000 & \\
\hline 14 & Trust & 0.000 & 0.715 & 0.753 & 0.259 & 0.000 & 0.000 & .001-.164 & .045-.527 & .001-.023 & 0.000 & \\
\hline 15 & Satisfaction & 0.000 & 0.777 & 0.713 & 0.927 & 0.000 & 0.000 & .001-.183 & 然. $001-690$ & $.125-.407$ & 0.000 & \\
\hline 16 & Confidence & 0.000 & 0.698 & 0.608 & 0.783 & 0.000 & 0.000 & & $.900-.927$ & $.016-.029$ & 0.000 & \\
\hline 17 & Trust & 0.000 & 0.700 & 0.763 & 0.393 & 0.000 & 0.000 & & 等. $049-.671$. & 等.003-.029. & 0.000 & \\
\hline 18 & Satisfaction & 0.000 & 0.765 & 0.697 & 0.819 & 0.000 & 0.000 & & .001-.772 & $.225-.409$ & 0.000 & \\
\hline 19 & Confidence & 0.000 & 0.688 & 0.372 & & 0.000 & 0.000 & & & $.011-.035$ & 0.000 & \\
\hline 20 & Trust & 0.000 & 0.688 & 0.912 & & 0.000 & 0.000 & & & 年 $.008-.065$ & 0.000 & \\
\hline 21 & Satisfaction & 0.000 & 0.749 & 0.709 & & 0.000 & 0.000 & & & .241-.401 & 0.000 & \\
\hline Note. & $\begin{array}{l}\text { Gray boxes indic } \\
\text { Model Fit is the } p \\
\text { Pseudo R-squared } \\
\text { T-P-Lines is the } p\end{array}$ & $\begin{array}{l}\text { gnificance at } \\
\text { le for the } x^{2} \mathrm{~s} \\
\text { the Nagelke }\end{array}$ & $\begin{array}{l}05 \text { level. } \\
\text { ic for mode } \\
\text { alculation } \\
\text { Parallel Lin }\end{array}$ & or valt & cant). & 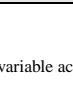 & ed for & model). & & & & \\
\hline
\end{tabular}




\section{CONFIDENCE IN LAW ENFORCEMENT}

The percent of variance in African-American attitudes toward local law enforcement explained in these models is very strong (other than the RMI-AA-only models 1-3) and ranges from $67.2 \%$ for model 5 to $78.3 \%$ for model 12 . At a glance, it is clear that African-American respondents' perceptions of Procedural Justice (Factor ${ }_{\mathrm{PJ}}$ ) and Police Effectiveness (Factor ${ }_{\mathrm{PE}}$ ), the factor scores generated in the Exploratory Factor Analysis above, are significant predictors of African-American confidence, trust, and satisfaction in local law enforcement. But contrary to the researcher's initial expectation, and consistent with all other statistical and graphical assessments above, the RMI-AA independent variable is not a significant predictor of African-American attitudes toward local law enforcement. Furthermore, the Ordinal Logistic Regression runs also illustrated that Adverse Police Contact is a marginal predictor of African-American attitudes toward local law enforcement but sex and age are significant predictors in most models. 


\section{CONFIDENCE IN LAW ENFORCEMENT}

\section{Chapter 5}

\section{Discussion}

This exploratory study revealed that although African-Americans' perceptions of police procedural justice and police effectiveness along with age and sex all strongly affect African-American attitudes toward local law enforcement, the African-American representativeness of local law enforcement agencies does not. Thus, positive AfricanAmerican confidence, trust, and satisfaction in local law enforcement did not require racial representativeness on the local police force; rather, they required police procedural justice and police effectiveness.

The survey in this study addressed civilian confidence, trust, and satisfaction in local law enforcement as measured by Likert-style items seeking responses to a series of statements regarding aspects of law enforcement service, such as, "The law enforcement officers in my community use rules and procedures that are fair to everyone," and "The law enforcement officers in my community are always ready to provide satisfactory assistance to victims of crime." That survey was conducted online, hosted on Qualtrics, and administered through Amazon Mechanical Turk ("MTurk") and TurkPrime. Those tools ensured that only African-American adults could complete the survey. Slightly in excess of 500 survey responses were received in a 24-hour period in February 2019. After data cleaning, 356 respondents remained in the database for statistical analysis. The respondents were slightly more female, older, and more Hispanic than the American African-American population as a whole. The analytical focus was framed by the four research questions.

Research question 1 asked which factors most efficiently summarize the variation 


\section{CONFIDENCE IN LAW ENFORCEMENT}

in the measured variables (the survey responses) related to African-American civilian confidence in local law enforcement. That sort of inquiry is best answered using Exploratory Factor Analysis ("EFA") denominated in SPSS-25 as Principal Axis

Factoring. After earlier EFA model runs on nearly all of the survey items, items related to neighborhood context and recent adverse police contact were removed from the factor analysis but retained for use as separate independent variables in the regression analyses. Thus, the EFA process considered just 19 items from the survey. Assessing the interdependence of the 19 remaining key survey items, EFA items coalesced those items onto just two factors that have been interpreted to capture concepts related to Procedural Justice (Factor 1) and Police Effectiveness (Factor 2) as described below:

\section{Table 7. Factor 1: Procedural Justice}

The law enforcement officers serving my community are usually honest.

The law enforcement officers serving my community treat everyone with respect. The law enforcement officers serving my community treat everyone with dignity. The law enforcement officers serving my community respect people's rights.

The law enforcement officers serving my community follow through on the decisions and promises they make.

The law enforcement officers serving my community always act within the law.

The law enforcement officers serving my community take account of the needs and concerns of people they deal with.

The law enforcement officers serving my community sincerely try to help people with their problems.

The law enforcement officers serving my community clearly explain the reasons for their actions.

The law enforcement officers serving my community provide opportunity for unfair decisions to be corrected.

The law enforcement officers serving my community use rules and procedures that are fair to everyone.

\section{Table 8. Factor 2: Police Effectiveness}

The law enforcement officers serving my community usually act within the law. The law enforcement officers serving my community respond promptly to calls about crimes (for example, robbery, assault).

The law enforcement officers serving my community are always ready to provide 


\section{CONFIDENCE IN LAW ENFORCEMENT}

satisfactory assistance to victims of crime.

The law enforcement officers serving my community are always ready to provide the assistance the public needs from them.

The law enforcement officers serving my community are doing well in controlling violent crime.

The law enforcement officers serving my community are doing a good job overall.

When law enforcement officers serving my community stop people, they usually handle the situation well.

This two-factor solution is consistent with Nadal and Davidoff (2015), who used the Perceptions of Police Scale ("POPS") to explore overall civilian beliefs about law enforcement bias. The items absorbed within each of those two factors also closely match this researcher's a priori prediction of the Satisfaction/Effectiveness and Confident components (supra, table 4, p. 43).

Research question 2 asked whether the factors derived in the Exploratory Factor Analysis for research question 1 were strongly associated with African-American civilian (a) confidence, (b) satisfaction, and (c) trust in local law enforcement. Spearman RankOrder Correlations ( $r h o$ or $\rho$ ) indicated that Factor 1 (Procedural Justice) was significantly associated with all three African-American civilian attitudes toward local law enforcement: Confidence $(\rho=.767 ; p=.000)$; Trust $(\rho=.741 ; p=.000)$; and Satisfaction $(\rho=.753 ; p=.000)$. Spearman Correlations also indicated that Factor 2 (Police Effectiveness) was significantly associated with all three civilian attitude categories: Confidence $(\rho=.746 ; p=.000)$; Trust $(\rho=.760 ; p=.000)$; and Satisfaction $(\rho=.815 ; p=.000)$.

Research question 3 asked whether African-Americans living in communities served by law enforcement agencies wherein African-Americans are underrepresented among sworn officers in those agencies have lower confidence in those local law enforcement agencies. Because the results of the earlier statistical approaches in this 


\section{CONFIDENCE IN LAW ENFORCEMENT}

study appeared to be counter-intuitive, that is, that African-American representativeness on local law enforcement agencies has no statistically significant association with African-American confidence in local law enforcement, a series of rigorous and intuitive approaches was used to verify the initial findings and rule out any unintended statistical and data artifacts. Specifically, Spearman's Rank-Order Correlation (rho or $\rho$ ), Kendall's tau-b $\left(\tau_{b}\right)$, Pearson's Product-Moment Correlation $(r)$, graphical representation, the Kruskal-Wallis $H$ Test, and Ordinal Logistic Regression were all used to explore various aspects of this unexpected result. At every turn and by every approach and statistical measure, African-American representativeness among sworn officers on the local law enforcement agency (computed herein as Racial Mirror Index-African American or RMIAA) failed to exhibit a statistically significant association with African-American confidence in local law enforcement and its associated concepts, trust and satisfaction. Thus, this exploratory study failed to find what had been expected, that communities where African-Americans are underrepresented among sworn law enforcement officers would exhibit concomitantly lower confidence, trust, and satisfaction in local law enforcement agencies than communities where the agencies failed to mirror the racial makeup on the communities the agencies served. This is certainly not the only study yielding surprising results regarding the impact of proportional Black representativeness in law enforcement (Barrick, Hickman, \& Strong, 2014). And the unexpected result of this study does not end the inquiry as is discussed in greater length in the Conclusions section below.

Research question 4 asked this question: if RMI-AA is modeled with other variables known to correlate with civilian confidence in law enforcement (including 


\section{CONFIDENCE IN LAW ENFORCEMENT}

neighborhood context, fear of crime, recent adverse police contact), is RMI-AA still - or does RMI-AA become - a significant predictor of African-American civilian confidence in local law enforcement. This question was answered using Ordinal Logistic Regression. All Ordinal Logistic Regression model runs that included RMI-AA as a model variable exhibited the same result: RMI-AA was not a significant predictor of African-American Confidence, Trust, or Satisfaction no matter the model specification, that is, RMI-AA was not a significant predictor of African-American attitudes toward local law enforcement whether RMI-AA was the sole independent variable or was combined with the two factors (Procedural Justice and Police Effectiveness), adverse police contacts, neighborhood context, age, sex, or Hispanic identity. Simply put, RMI-AA does not predict African-American attitudes toward local law enforcement.

\section{Policy Implications}

At first glance, the finding here that increased African-American representativeness does not significantly improve African-American attitudes toward local law enforcement may tempt local law enforcement agencies to downplay or discontinue efforts to increase diversity among sworn officers. After all, it facially conflicts with Recommendation 1.18 .1 of the President's Task Force on 21st Century Policing (2015, p. 17). But that simplistic reaction ignores the many other benefits of the "complicated issue of diversity" that can be achieved by increasing the number and proportion of African-Americans on the force identified as one of the goals by Pillar 1 and Recommendation 1.8 of the President's Task Force on $21^{\text {st }}$ Century Policing (2015, pp. 2, 18).

Having more Black officers on the force will reduce police shootings of Black 


\section{CONFIDENCE IN LAW ENFORCEMENT}

civilians once a sufficient threshold is reached (Dunham \& Petersen, 2017; Legewie \& Fagan, 2016; Nicholson-Crotty, Nicholson-Crotty, \& Fernandez, 2017; Sekhon, 2017). Black officers are less likely to fall into "driving while Black” inertia (Fagan, Braga, Brunson, \& Pattavina, 2016; Gilliard-Matthews, Kowalski, \& Lundman, 2008). Increasing minority representativeness may improve agencies' community policing efforts (Hall, Hall, \& Perry, 2016, p. 18-19; Schuck, 2014) and has been shown to reduce both the absolute number of excessive force complaints and the number of upheld complaints (Hong, 2016). And more specifically, Hong (2017) argued that increasing the ethnic proportion of officers on an agency by just $1.58 \%$ yielded a $20-39 \%$ decrease in the number of ethnic civilians stopped and searched.

Beyond those direct benefits related to improving Black representation among sworn officers in local law enforcement agencies, and despite some cautionary commentary regarding the threats sometimes posed by workplace diversity (Cletus, Mahood, Umar, \& Ibrahim, 2018; Weitzer, 2015), myriad benefits can flow from increased diversity within each agency, including fostering innovation (Lambert, 2016; Rock \& Grant, 2016), improving performance (Roberson, Ryan, \& Ragins, 2017), increasing depth of perspectives and breadth of worldviews (Galinsky, et al., 2015), and reflecting civilian preferences for a racially mixed but not necessarily mirror image police force (Weitzer, 2018), among others.

Finally, although this study makes clear that communities with greater AfricanAmerican representativeness in local law enforcement agencies do not exhibit greater African-American civilian confidence, trust, and satisfaction in local law enforcement, other benefits to increased law enforcement diversity justify continued efforts to increase 


\section{CONFIDENCE IN LAW ENFORCEMENT}

diversity and representativeness.

Inasmuch as the results herein indicate that Black distrust in officers is relatively consistent without substantive regard for the degree of African-American representativeness on the local police force, the obvious focus must be on the core challenge: how to improve African-American confidence, trust, and satisfaction in local law enforcement. That target, of course, implicates the two factors identified here: African-American perceptions of procedural justice and African-American perceptions of police effectiveness. It appears that strategies to improve African-American confidence in law enforcement and reduce the race gap in trust is entirely in law enforcement's hands: hire to improve diversity for diversity's per se benefits; hire to improve procedural justice; model, exhibit, and require procedural justice at all levels of the organization; and strive to be effective in keeping communities and civilians safe and protected. Law enforcement's path forward is paved with those stones.

At bottom, this rather surprising finding informs law enforcement that confidence, trust, and satisfaction are more than mere reflections of the degree of minority representativeness. Rather, it appears law enforcement's strategies going forward and the targets and action plans contained within the President's Task Force on 21st Century Policing (2015) both need to focus primary efforts on diversity (Pillar 1 and Recommendation 2.18 , pp. 2,16 ), but even more so must focus on enhanced procedural justice and effectiveness to improve African-American attitudes toward law enforcement.

\section{Limitations}

The use of LEMAS 2013 data renders the analysis a bit stale as the 2016 LEMAS data has already been collected and is expected to be released shortly after this study is 


\section{CONFIDENCE IN LAW ENFORCEMENT}

completed. The researcher will rerun his analysis and publish the updated findings using that 2016 LEMAS data after those data are released in late 2019 or early 2020 (Savolainen, 2019).

The lack of a qualitative phase in a mixed methods sense renders the resulting data here a bit more difficult to interpret. Future studies could add a qualitative component, perhaps via a semi-structured, follow-up interview of selected survey respondents, to better assess the underpinnings of African-American confidence, trust, and satisfaction in local law enforcement.

To the extent the large number of public confidence data points (the individual survey items) suffer from multicollinearity, that may skew, exaggerate, or blur the results. Although Exploratory Factor Analysis, to a large extent, resolves such multicollinearity issues by extracting coalesced factors, the researcher believes it may still be wise to (1) pare back some of survey items 5-37 to mitigate any multicollinearity issues; (2) use only the single pure confidence, trust, or satisfaction items (items 11, 31, and 35); or (3) rely on an additive or mean "master confidence" score to ameliorate any multicollinearity problems.

The responses to the online survey were self-reported and without oral feedback for clarification; although outlier answers - high and low - may cancel each other out it may be wise to cautiously exclude apparent outliers from further analysis on the next iteration.

Using an online survey panel of African-American adults is likely to skew respondent demographics toward higher education than the general public but multiple studies have found that panel-based survey approaches yield equivalent results to other 


\section{CONFIDENCE IN LAW ENFORCEMENT}

classical surveying approaches. Future research could identify differences in responses given different collection methods: online survey panel (as herein), mailed survey, focus group, and so on.

Given that the survey respondents self-select their participation online through MTurk and TurkPrime, this study suffers from some of the limitations endemic in convenience samples. The researcher recommends that future researchers strive to mitigate this limitation by drawing a greater breadth of survey respondents to the survey and by using online survey panels from multiple vendors and not just a single vendor such as MTurk.

The final limitation arises from the complexity of models that drive or seek to measure civilian confidence in police. Although this study reflects and expands upon earlier scholars' work on point, it is possible that focusing on race and racial representativeness alone may not be the most direct path for improving civilian confidence in law enforcement. Indeed, this study finds that the African-American confidence in law enforcement race gap exists almost without regard to AfricanAmerican representativeness on the force. Therefore, further research into the basal triggers of African-American distrust in law enforcement should bear greater fruit than further explication of the minimal, if any, impact of RMI-AA on trust. After all, Ozkan, Worrall, \& Piquero (2016) found that improving minority representativeness did not reduce the number of civilian assaults on police although improved police/civilian interactions and community-oriented policing can do so (pp. 402, 416-419). Similarly, Shjarback, Decker, et al. (2017) found that increased racial representation did not reduce racial disparity in traffic stops (pp. 759-760). And to the contrary, Ferrandino (2014) 


\section{CONFIDENCE IN LAW ENFORCEMENT}

found that increasing minority representativeness improved or at least did not impede clearance rates and efficiency scores of 200 Florida law enforcement agencies. Therefore, from a practical policing standpoint, even though this study may shed additional light on the failure of many agencies to mirror their served communities, more direct paths may spring more directly from either individual outreach efforts or from other approaches largely uncoupled from racial makeup on law enforcement agencies, including programs targeting youth, good press relations, or decentralized law enforcement administration (Brown \& Benedict, 2002); improving procedural justice, increasing foot patrols, problem-oriented policing, and community reassurances (Haberman, et al., 2016); generalized increased agency emphasis on improving civilian sentiment (Johnson, 2015); community-oriented policing approaches (Liou \& Savage, 1996; O’Neill, 2015, pp. 77, 86; Thomas \& Burns, 2005), p. 84); improving respectful police behavior (Tyler \& Huo, 2002, p. 163). "When [civilians] felt that legal authorities were polite and respectful, sincere and concerned for their rights, and did not harass community residents, they were more supportive of the law and legal authorities" (Tyler \& Huo, 2002, p. 197).

\section{Recommendations for Future Research}

This researcher will rerun the analysis with the 2016 LEMAS data, which will not be released until summer 2019 or later. And later replications of this study should include other races and ethnicities to assess the universality of the findings here - that civilian attitudes toward law enforcement are driven by procedural justice and police effectiveness.

Small-scale improvements include using more Likert-style gradations than the three used herein. Although that may not dramatically improve or clarify the findings 


\section{CONFIDENCE IN LAW ENFORCEMENT}

since a substantial question remains whether participants accurately, consistently, and successfully can differentiate, for example, between "disagree" and "strongly disagree," that would permit use of more parametric analyses given that the ordinal data - with more categories - would mimic continuous data.

This analysis used residential zip code data (verified by IP address) provided by each participant to determine the local law enforcement agency to assign to each participant; future rounds should consider asking each participant in a text question on the survey to identify the law enforcement agency serving that participant's community.

Mixed methods approaches would help strengthen and explain the findings. Follow-up semi-structured interviews with selected participants would allow the researcher to explore the components that aggregate into confidence, trust, and satisfaction. 


\section{CONFIDENCE IN LAW ENFORCEMENT}

\section{References}

Alberton, A. M., \& Gorey, K. M. (2018). Contact is a stronger predictor of attitudes toward police than race: A state-of-the-art review. Policing: An International Journal of Police Strategies and Management, 41(1), 2-23.

Amazon Web Services (2017). Amazon Mechanical Turk: Mechanical Turk concepts. Retrieved from

https://docs.aws.amazon.com/AWSMechTurk/latest/RequesterUI/mechanicalturk-concepts.html

Andover Police Department (2016). Complaint investigations statistical summary \& citizen satisfaction survey results: 2016 annual report. Retrieved from https://www.andoverks.com/DocumentCenter/View/5629/2016-ComplaintInvestigations-and-Citizen-Survey-Statistical-Summary?bidId=

Antrobus, E., Bradford, B., Murphy, K., \& Sargeant, E. (2015). Community norms, procedural justice, and the public's perceptions of police legitimacy. Journal of Contemporary Criminal Justice, 31(2), 151-170.

Ashkenas, J., \& Park, H. (2015, April 18). The race gap in America's police departments. New York Times. Retrieved from https://www.nytimes.com/interactive/2014/09/03/us/the-race-gap-in-americaspolice-departments.html

Associated Press (2015, July 27). Lynch: Easing distrust between minorities, police a top goal. Retrieved from http://www.cnsnews.com/news/article/lynch-easing-distrustbetween-minorities-police-top-goal

Auter, Z. (2016, April 8). State residents generally feel secure but racial divisions exist. Gallup Analytics. Retrieved from http://news.gallup.com/poll/190553/stateresidents-generally-feel-secure-but-racial-divisions-exist.aspx

Bacon, J., \& Eversley, M. (2016, Apr. 19). No jail time for NYPD cop who shot unarmed black man. USA Today. Retrieved from

https://www.usatoday.com/story/news/nation/2016/04/19/nypd-officer-who-shotunarmed-man-faces-sentencing/83221906/

Baker, T., Pickett, J. T., Amin, D. M., Golden, K., Dhungana, K., Gertz, M., \& Bedard, L. (2015). Shared Race/Ethnicity, court procedural justice, and self-regulating beliefs: A study of female offenders. Law \& Society Review, 49(2), 433-465.

Ballard, C., \& Prine, R. (2002). Citizen perceptions of community policing: Comparing internet and mail survey responses. Social Science Computer Review, 20(4), 485493. 


\section{CONFIDENCE IN LAW ENFORCEMENT}

Barajas, J. (2017, Jul. 11). Minnesota officer acquitted in fatal shooting of Philando Castile to receive buyout. Public Broadcasting System. Retrieved from https://www.pbs.org/newshour/nation/minnesota-officer-acquitted-fatal-shootingphilando-castile-receive-buyout

Barboza, G. E. (2012). Group consciousness, identity, and perceptions of unfair police treatment among Mexican Americans. Policing: An International Journal of Police Strategies and Management, 35(3), 506-527.

Barker, V. (2016). "Policing difference" in Bradford, B., Loader, I., Jauregui, B., \& Steinberg, J., eds. (2016). The SAGE Handbook of Global Policing. Thousand Oaks CA: Sage Publishing.

Barrick, K. (2014). Latino confidence in the police: The role of immigration enforcement, assimilation, and immigration status. Journal of Ethnicity in Criminal Justice, 12(4), 289.

Barrick, K., Hickman, M., \& Strom, J. (2014). Representative policing and violence towards the police. Policing, 8, 193-204.

Bayley, D. H., Davis, M. A., \& Davis, R. L. (2015, June). Race and policing: An agenda for action. New Perspectives in Policing. Harvard Kennedy School. Retrieved from https://www.hks.harvard.edu/content/download/76431/1714462/version/1/file/Ra ceandPolicing.pdf

Becerra, D., Wagaman, M. A., Androff, D., Messing, J., \& Castillo, J. (2017). Policing immigrants: Fear of deportations and perceptions of law enforcement and criminal justice. Journal of Social Work, 17(6), 715-731.

Bekiempis, V. (2015, May 14). The new racial makeup of U.S. police departments. Newsweek. Retrieved from http://www.newsweek.com/racial-makeup-policedepartments-331130

Berman, M. (2017, July 18). Prosecutors won't seek third trial for former Ohio police officer who shot Samuel DuBose. The Washington Post. Retrieved from https://www.washingtonpost.com/news/post-nation/wp/2017/07/18/prosecutorswont-seek-third-trial-for-former-ohio-police-officer-who-shot-samueldubose/?utm_term=.efbb1895833f

Berube, A., \& Holmes, N. (2016). Minority under-representation in city and suburban policing. Washington: Brookings Institution Press. Retrieved from https://www.brookings.edu/blog/the-avenue/2016/07/14/minority-underrepresentation-in-city-and-suburban-policing/

Black Demographics (2019a). Population: Black population by state. Retrieved from https://blackdemographics.com/population/black-state-population/ 


\section{CONFIDENCE IN LAW ENFORCEMENT}

Black Demographics (2019b). Regional distribution of the Black population. Retrieved from https://blackdemographics.com/population/black-regions/

Boateng, F. D., Lee, H. D., \& Abess, G. (2016). Analyzing citizens' reported levels of confidence in the police: A cross-national study of public attitudes toward the police in the United States and South Korea. Asian Journal of Criminology, 11(4), 289-308.

Bolten, K. A. (2015, October 12). Largely white police forces fuel minority distrust. Des Moines Register. Retrieved from http://www.desmoinesregister.com/story/news/2015/10/10/racial-makeup-lawenforcement-agencies/32525523/

Bottoms, A., \& Tankebe, J. (2012). Criminology: Beyond procedural justice: A dialogic approach to legitimacy in criminal justice. Journal of Criminal Law \& Criminology, 102(1), 119-170.

Bouranta, N., Siskos, Y., \& Tsotsolas, N. (2015). Measuring police officer and citizen satisfaction: Comparative analysis. Policing: An International Journal of Police Strategies \& Management, 38(4), 705-721.

Bowling, B., \& Phillips, C. (2003). Policing ethnic minority communities, ch. 21 at 528555 in Newburn, T. (ed.) (2003). Handbook of Policing. Devon UK: Willan ublishing.

Bradford, B., Murphy, K., \& Jackson, J. (2014). Officers as mirrors: Policing, procedural justice and the (re)production of social identity. British Journal of Criminology, $54,527-550$.

Bradford, B., \& Myhill, A. (2015). Triggers of change to public confidence in the police and criminal justice system: Findings from the British Crime Survey panel experiment. Criminology \& Criminal Justice, 15(1), 23-43.

Bradley, C., Brooks, J., \& Allen, A. (2017, July). Dotham community survey analytical report. Retrieved from https://trojan.troy.edu/artsandsciences/socialsciences/assets/reports/DothanReport.pdf

Brandl, S.G., \& Stroshine, M.S. (2012). The role of officer attributes, job characteristics, and arrest activity in explaining police use of force. Criminal Justice Policy Review, 20(10), 1-22.

Branham, D. (2018, September 24). Dallas officer Amber Guyger fired after manslaughter charge for killing Botham Jean. Dallas News. Retrieved from https://www.dallasnews.com/news/dallas-police/2018/09/24/dallas-officer-amberguyger-fired-after-manslaughter-charge-killing-botham-jean 


\section{CONFIDENCE IN LAW ENFORCEMENT}

Brown, B., \& Benedict, W. R. (2002). Perceptions of the police: Past findings, methodological issues, conceptual issues, and policy implications. Policing: An International Journal of Police Strategies \& Management, 25(3), 543-580.

Buhrmester, M., Kwang, T., \& Gosling, S. D. (2016). Amazon's mechanical turk: A new source of inexpensive, yet high-quality data? In A. E. Kazdin (Ed.), 4th ed.; methodological issues and strategies in clinical research (4th ed.) (4th ed. ed., pp. 133-139, Chapter xviii, 703 Pages) APA, American Psychological Association, Washington,

Burnap, N, \& Research Strategies, Inc. (2017, June). 2017 Greenville Police Department community survey. Retrieved from http://police.greenvillesc.gov/DocumentCenter/View/9609/2017-GreenvillePolice-REPORT-PDF-6-14-17?bidId=

CACP (2017a, 2017b). See Canadian Association of Chiefs of Police Global (2017a, 2017b), infra.

Callanan, V. J., \& Rosenberger, J. S. (2011). Media and public perceptions of the police: Examining the impact of race and personal experience. Policing \& Society, 21(2), 167-189.

Canadian Association of Chiefs of Police Global (2017a) ("CACP, 2017a"). Trust matters: An executive summary report for the Canadian Association of Chiefs of Police Board of Directors on the proceedings and outcomes of the 10th cohort. Retrieved from http://www. cacpglobal.ca/images/2017cohort/CACP_Global_Studies_2017_-_ Summary_Report_-_Trust_Matters_July_18.pdf

Canadian Association of Chiefs of Police Global. (2017b) (“CACP, 2017b"). Trust matters: The principles. Retrieved from https://www.google.ca/search?q=Trust+matters:+The+principles.+Info graphic+depicting+the+genetic+code+of+public+trust.\&tbm=isch\&tbo $=\mathrm{u} \&$ source $=$ univ\&sa $=$ X\&ved=0ahUKEwis1LDOv8PXAhWD5IMKHfFyB DAQsAQIJQ\&biw $=1280 \&$ bih $=627$

Cao, L. (2011). Visible minorities and confidence in the police. Canadian Journal of Criminology \& Criminal Justice, 53(1), 1-26.

Cao, L. (2015). Differentiating confidence in the police, trust in the police, and satisfaction with the police. Policing: A Journal of Policy and Practice, 38(2), 239-249.

Cao, L., Lai, Y-L, \& Zhao, R. (2012). Shades of blue: Confidence in the police in the world. Journal of Criminal Justice, 40, 40-49. 


\section{CONFIDENCE IN LAW ENFORCEMENT}

Casstevens, S. R. (2017). Buffalo Grove Police Department 2017 citizen survey.

Retrieved from http://www.vbg.org/DocumentCenter/View/3288/2017-CITIZENSURVEY?bidId=

CD Light, L.L.C. (2019). ZIP code database. Retrieved from http://www.zipinfo.com/search/zipcode.htm

Cera, J., \& Coleman, A. (2014). City of Milwaukee police satisfaction survey. Retrieved from https://city.milwaukee.gov/ImageLibrary/Groups/cityFPC/Reports/150122_Police _Satisfaction_Survey.pdf

Chapman, C. (2012). Use of force in minority communities is related to police education, age, experience, and ethnicity. Police Practice \& Research, 13(5), 421-436.

Charles, S. (2018, Jan. 19). No cops to be charged in 2016 shooting of Paul O'Neal. Chicago Sun-Times. Retrieved from https://chicago.suntimes.com/news/no-copsto-be-charged-in-2016-shooting-of-paul-oneal/

Cheng, H. (2015). Factors influencing public satisfaction with the local police: A study in Saskatoon, Canada. Policing: A Journal of Policy and Practice, 38(4), 690-704.

City of Rochester, Michigan (2017, April). City of Rochester, Michigan citizen survey report. Retrieved from http://www.ci.rochester.mi.us/DocumentCenter/View/2037/2017-CommunitySurvey-Final-Report?bidId=

City of Warren PA (2017). Police satisfaction survey. Retrieved from https://www.cityofwarrenpa.gov/?SEC=41D77113-E9E2-4FB3-AD19D8DF12814FB3

Clark, M., Davidson, R., Hanrahan, V., \& Taylor, N.E. (2017). Public trust in policing: A global search for the genetic code to inform policy and practice in Canada. Journal of Community Safety \& Well-Being, 2(3), 1-18.

Cletus, H. E., Mahmood, N. A., Umar, A., \& Ibrahim, A. D. (2018). Prospects and challenges of workplace diversity in modern ay organizations: A critical review. Holistica, 9(2), 35-52.

Cobb, J. (2018, Apr. 5). Stephon Clark and the shooting of black men, armed and unarmed. The New Yorker. Retrieved from https://www.newyorker.com/news/daily-comment/stephon-clark-and-theshooting-of-black-men-armed-and-unarmed

Cochran, J. C., \& Warren, P. Y. (2011). Racial, ethnic, and gender differences in perceptions of the police: The salience of officer race within the context of racial profiling. Journal of Contemporary Criminal Justice, 20(10), 1-22. 


\section{CONFIDENCE IN LAW ENFORCEMENT}

Cohen, J. (1988). Statistical power analysis for the behavioral sciences. Hillsdale NJ: Erlbaum Associates.

Correia, M. E., Reisig, M. D., \& Lovrich, N. P. (1996). Public perceptions of state police: An analysis of individual-level and contextual variables. Journal of Criminal Justice, 24(1), 17-28.

Cotton, A., Haynes, D., \& Wells, W. (2012, October). Baltimore City citizen survey: 2012 report. Retrieved from https://finance.baltimorecity.gov/sites/default/files/citizensurvey.pdf

Cronbach L. J. (1951). Coefficient alpha and the internal structure of tests. Psychometrika, 16, 297-334.

CRS (2010). See United States Department of Justice, Community Relations Service (2010), infra.

Dai, M., \& Jiang, X. (2016). A comparative study of satisfaction with the police in the United States and Australia. Australian and New Zealand Journal of Criminology, 49(1), 30-52.

Dai, M., \& Johnson, R. R. (2009). Is neighborhood context a confounder? Exploring the effects of citizen race and neighborhood context on satisfaction with the police. Policing: An International Journal of Police Strategies \& Management, 32(4), 595-612.

Dallas Morning News (2015, May). Texas law enforcement often doesn't mirror the communities it serves. Retrieved from http://res.dallasnews.com/graphics/2015_05/texas-racial-divide/

Davis, M., Camel, D., Mozee, S., \& Granger, M. (2016, March). Research brief: Perception of safety, and trust in police officers, police department, and the judicial system including courts. Retrieved from http://www.jsums.edu/murc/files/2014/07/Final-Research-Brief-2-2016.pdf

DeAngelis, J., \& Kupchik, A. (2007). Citizen oversight, procedural justice, and officer perceptions of the complaint investigation process. Policing: An International Journal of Police Strategies \& Management, 30(4), 651-671.

DeAngelis, J., \& Wolf, B. (2016). Perceived accountability and public attitudes toward local police. Criminal Justice Studies: A Critical Journal of Crime, Law \& Society, 29(3), 232-252.

DePillis, L. (2014, August 22). Do diverse police forces treat their communities more fairly than almost-all-white ones like Ferguson's? Washington Post. Retrieved from https://www.washingtonpost.com/news/storyline/wp/2014/08/22/do-diversepolice-forces-treat-their-communities-more-fairly-than-all-white-ones-likefergusons/ 


\section{CONFIDENCE IN LAW ENFORCEMENT}

DHM Research (2018, September). City of Salem 2018 survey. Retrieved from https://www.cityofsalem.net/CityDocuments/2018-community-satisfactionsurvey.pdf

Dotsquare L.L.C. (2019). Batch geocode a spreadsheet; geocodio. Retrieved from https://www.geocod.io/upload/

Drake, B. (2015, Apr. 28). Divide between blacks and whites on police runs deep. Pew Research Center. Retrieved from http://www.pewresearch.org/facttank/2015/04/28/blacks-whites-police

Dukes, R. L., Portillos, E., \& Miles, M. (2009). Models of satisfaction with police service. Policing: An International Journal of Police Strategies and Management, 32(2), 297-318.

Dunham, R. G., \& Petersen, N. (2017). Making Black lives matter: Evidence-based policies for reducing police bias in the use of deadly force. Criminology \& Public Policy, 16(1), 341-348.

Ekins, E. (2017a). Policing in America: Understanding public attitudes toward the police. Results from a national survey. Cato Institute. Retrieved from https://object.cato.org/sites/cato.org/files/survey-reports/pdf/policing-in-americaaugust-1-2017.pdf

Ekins, E. (2017b). Deep racial divide in perceptions of police and reported experiences, no group is anti-cop. Cato Institute. Public Information Briefs. Retrieved from https://object.cato.org/sites/cato.org/files/pubs/pdf/public-opinion-briefs-1.pdf

Estrada, S. (2015, January 27). Addressing the perceptions of law enforcement prejudice. Diversity, Inc. News. Retrieved from http://www.diversityinc.com/news/addressing-perceptions-law-enforcementprejudice/

ETC Institute (2016, August). City of Durham police satisfaction survey: Findings report. Retrieved from https://durhamnc.gov/DocumentCenter/View/14202/Durham-Police-SatisfactionSurvey-Findings-Report?bidId=

ETC Institute (2018a). 2017 City of Columbia DirectionFinder ${ }^{\circledR}$ survey: Final report. Retrieved from https://www.como.gov/wp-content/uploads/2017-Survey-FinalReport-summary-charts-benchmarks-IS-analysis-tabular-data-instrument.pdf

ETC Institute (2018b). 2017 City of Las Vegas community survey: Findings report. Retrieved from https://files.lasvegasnevada.gov/transparency/Citizens-SurveyResults.pdf

ETC Institute (2018c). 2018 City of Pueblo community survey. Retrieved from https://www.pueblo.us/DocumentCenter/View/21017/2018-final-report 


\section{CONFIDENCE IN LAW ENFORCEMENT}

Evesham Police Department (2018). Evesham Police Department customer satisfaction survey. Retrieved from http://www.eveshampd.org/pdf/2018\%20Citizen\%20Satification\%20Survey.pdf

Fagan, J., Braga, A. A., Brunson, R., \& Pattavina, A. (2016). Stops and stares: Street stops, surveillance, and race in the new policing. Fordham Urban Law Journal, 43, 539-614.

Ferner, M. (2016, Dec. 19). LA Sheriff's Department admits deputy killed an unarmed, innocent man. Huffington Post. Retrieved from https://www.huffingtonpost.com/entry/donnell-thompsonshooting_us_57aa64b7e4b0ba7ed23e1a71

Ferrandino, J. A. (2014). The relationship between police minority equity levels and performance outcomes. Journal of Ethnicity in Criminal Justice, 12(2), 69-92.

Fisher-Stewart, G. (2007). Community policing explained: A guide for local governments. Retrieved from https://cops.usdoj.gov/pdf/vets-to-cops/cp_explained.pdf

Fitzpatrick, K. M., \& Myrstol, B. A. (2010). Northwest Arkansas community survey: A quality-of-life assessment of NWA residents. Retrieved from https://fulbright.uark.edu/departments/sociology/_resources/pdf/1003.02.nwacsfor web.pdf

Flexman-Evans, S. L. (2009, September). The Anchorage community survey, 2007: Sourcebook. Retrieved from https://scholarworks.alaska.edu/bitstream/handle/11122/4174/0508.022.2007sourc ebook.pdf? sequence $=8$

Forster-Towne, C. (2012). Labour, inequality and calls for representative police. Nordiska Afrikainstitutet. Retrieved from http://www.divaportal.org/smash/get/diva2:689656/FULLTEXT01.pdf

Frank, J., Brandl, S., Cullen, F., \& Stichman, A. (1996). Reassessing the impact of race on citizens' attitudes toward the police. Justice Quarterly, 13, 321-334.

Friedman, B., \& Ponomarenko, M. (2015). Democratic policing. New York University Law Review, 90(6), 1827-1907.

Galinsky, A. D., Todd, A. R., Homan, A. C., Phillips, K. W., Apfelbaum, E. P., Sasaki, S. J., Richeson, J. S., Olayon, J. B., \& Maddux, W. W. (2015). Maximizing the gains and minimizing the pains of diversity: A policy perspective. Perspectives on Psychological Science, 10(6), 742-748.

Garcia, V., \& Cao, L. (2005). Race and satisfaction with the police in a small city. Journal of Criminal Justice, 33, 191-199. 


\section{CONFIDENCE IN LAW ENFORCEMENT}

Garner, J. H., Maxwell, C. D., \& Heraux, C. G. (2002). Characteristics associated with the prevalence and severity of force used by the police. Justice Quarterly, 19(4), 705-746.

Gau, J. M. (2010). A longitudinal analysis of citizens' attitudes about police. Policing: An International Journal of Police Strategies and Management, 33(2), 236-252.

Giblin, M. J. (2003). A further perspective on satisfaction with policing. Alaska Justice Forum, 20(3), 2-4. Retrieved from https://www.uaa.alaska.edu/academics/college-of-health/departments/justicecenter/alaska-justice-forum/20/3fall2003/b_policing.cshtml

Gillespie, M. (2015, October 15). FBI director laments divide between police, minorities. Washington Times. Retrieved from https://www.washingtontimes.com/news/2015/oct/15/fbi-director-laments-dividebetween-police-minorit/

Gillette Wyoming Communications Division (2017). 2017 citizen survey report. Retrieved from https://www.gillettewy.gov/home/showdocument?id=33177

Gilliard-Matthews, S., Kowalski, B. R., \& Lundman, R. J. (2008). Officer race and citizen-reported traffic ticket decisions by police in 1999 and 2002. Police Quarterly, 11(2), 202-219.

Gillum, J. (2014, September 7). Attention turns to racial balance between police forces, communities they serve. Deseret News. Retrieved from http://www.deseretnews.com/article/765659281/AP-Exclusive-Police-short-onHispanic-officers.html?pg=all

Goldberg, B. (2018, Oct. 5). Factbox: Trials of U.S. police officers charged with killing black men. Reuters. Retrieved from https://www.reuters.com/article/us-chicagopolice-killings-factbox/factbox-trials-of-u-s-police-officers-charged-with-killingblack-men-idUSKCN1MF2K8

Gomez, J. A., Jean-Charles, S., Zhao, Q., Zhao, W., \& Zou, R. (2012). Town of Wrentham, MA: 2012 citizen satisfaction survey. Retrieved from http://www.wrentham.ma.us/files/Wrentham\%20Website\%20Files/Town\%20Gov ernment $\% 20$ Study\%20Committee/Final\%20Report\%20of\%20Wrentham\%20Citi zen\%20Sastication\%20Survey\%201.pdf

Gonzaga University (2019). Parallel engine calculator. Retrieved from analysis.gonzaga.edu/parallelengine/

Gottlieb, A. (2017). The effect of message frames on public attitudes toward criminal justice reform for nonviolent offenses. Crime \& Delinquency, 3(5), 636-656. 


\section{CONFIDENCE IN LAW ENFORCEMENT}

Governing (2015, September). Diversity of the force: Where police don't mirror communities: A Governing special report. Retrieved from http://media.navigatored.com/documents/policediversityreport.pdf

Governing Data (2015). Police department race and ethnicity demographic data. Retrieved from http://www.governing.com/gov-data/safety-justice/policedepartment-officer-demographics-minority-representation.html

Gresham, D., Milford, B., \& Fowler, S. (2017, September). 2017 Thomasville Police public opinion survey results. Retrieved from https://thomasville.org/uploads/groups/3/Documents/Police/2017-ThomasvillePolice-Public-Opinion-Survey-Results.pdf

Haack, L. M. (2009) . An Examination of Missoula Citizens' Perceptions of Local Law Enforcement. Graduate Student Theses, Dissertations, \& Professional Papers. No. 130. Retrieved from https://scholarworks.umt.edu/etd/130

Haberman, C. P., Groff, E. R., Ratcliffe, J. H., \& Sorg, E. T. (2016). Satisfaction with police in violent crime hot spots: Using community surveys as a guide for selecting hot spots policing tactics. Crime \& Delinquency, 62(4), 525-557.

Hall, K. (2016, Dec 24). Austin police remain less diverse than city. Austin American Statesman. Retrieved from https://www.pressreader.com/usa/austin-americanstatesman/20161224/textview

Hall, A. V., Hall, E. V., \& Perry, J. (2016). Black and blue: Exploring racial bias and law enforcement in the killings of unarmed Black male citizens. American Psychologist, 71(3), 175-186.

Hannah-Jones, N. (2015, March 4). Yes, Black America fears the police. Here's why. ProPublica. Retrieved from https://www.propublica.org/article/yes-blackamerica-fears-the-police-heres-why

Harkin, D. (2015). Police legitimacy, ideology and qualitative methods: A critique of procedural justice theory. Criminology \& Criminal Justice, 15(5), 594-612.

Hawai'i Police Department (2016). Community satisfaction survey 2016. Retrieved from http://www.hawaiipolice.com/wp-content/uploads/2011/10/2016-CommunitySatisfaction-Summary1.pdf

Hayward Police (2017). Satisfaction survey results. Retrieved from https://www.hayward-ca.gov/police-department/satisfaction-survey-results

Heen, M. S. J., Lieberman, J. D., and Miethe, T. D. (2014). A Comparison of Different Online Sampling Approaches for Generating National Samples. University of Nevada Las Vegas: Center for Crime and Justice Policy. Retrieved from https://www.unlv.edu/sites/default/files/page_files/27/ComparisonDifferentOnline Sampling.pdf 


\section{CONFIDENCE IN LAW ENFORCEMENT}

Hickman, M. J., \& Piquero, A. R. (2009). Organizational, administrative, and environmental correlates of complains about police use of force: Does minority representation matter? Crime \& Delinquency, 55(1), 3-27.

Hinds, L. (2009). Public satisfaction with police: the influence of general attitudes and police-citizen encounters. International Journal of Police Science \& Management, 11(1), 54-66.

Ho, A. T-K, \& Cho, W. (2016). Government communication effectiveness and satisfaction with police performance: A large-scale survey study. Public Administration Review, 77(2), 228-239.

Holland, J. J. (2014, August 19). Police mistrust still prevalent years later. US News \& World Report. Retrieved from http://www.usnews.com/news/politics/articles/2014/08/19/police-mistrust-stillprevalent-years-later

Hollis Police Department (2018). Community satisfaction survey. Retrieved from http://www.hollisnh.org/police/2018\%20Citizen\%20Survey/HPD\%20Community \%20Survey\%20Results\%20Report_JUL_2018_ABBREVIATED.pdf

Hong, S. (2016). Representative bureaucracy, organizational integrity, and citizen coproduction: Does an increase in police ethnic representativeness reduce crime? Journal of Policy Analysis and Management, 35(1), 11-33.

Hong, S. (2017a). Does increasing ethnic representativeness reduce police misconduct? Public Administration Review, 77(2), 195-205.

Hong, S. (2017b). Black in blue: Racial profiling and representative bureaucracy in policing revisited. Journal of Public Administration Research and Theory, 27(4), 547-561.

Horwitz, E. (2014, Dec. 4). An interpretation of the grand jury's decision on Eric Garner's death. Boston Globe. Retrieved from https://www.bostonglobe.com/metro/2014/12/04/understanding-eric-garner-deathand-grand-jury-decision/s9uQPMvcKPD2mAmFy2ln9J/story.html

Hough, M. (2012). Researching trust in the police and trust in justice: A UK perspective. Policing \& Society, 22(3), 332-345.

Howell, S., Perry, H., \& Vile, M. (2004). Black cities, White cities: Evaluating the police. Political Behavior, 26, 45-68.

Huebner, B. M., Schafer, J. A., \& Bynum, T. S. (2004). African American and White perceptions of police services: Within- and between-group variation. Journal of Criminal Justice, 32, 123-135. 


\section{CONFIDENCE IN LAW ENFORCEMENT}

Hunt, V., Layton, D., \& Prince, S. (2015, January). Why diversity matters. McKinsey \& Company. Retrieved from https://www.mckinsey.com/businessfunctions/organization/our-insights/why-diversity-matters

Hyland, S., Langton, L., \& Davis, E. (2015, November). Police use of nonfatal force, 2002-11. U.S. Department of Justice, Office of Justice Programs, Bureau of Justice Statistics. Retrieved from https://www.bjs.gov/content/pub/pdf/punf0211.pdf

IBM (2018). Statistical package for the social sciences, version 25 (“SPSS-25”).

Iowa City Police Department (2016). Iowa City Police Department community survey results. Retrieved from https://www.icgov.org/city-government/departments-anddivisions/police-department/iowa-city-police-department-community

Jackson, B. A. (2015). Respect and legitimacy-A two-way street: Strengthening trust between police and the public in an era of increasing transparency. RAND Corporation. Retrieved from https://www.rand.org/pubs/perspectives/PE154.html

Jackson, J., Bradford, B., Hough, M., Myhill, A., Quinton, P., \& Tyler, T. R. (2012). Why do people comply with the law? British Journal of Criminology, 52(6), 1051-1071.

Jackson, J., \& Gau, J. M. (2016). Carving up concepts? Differentiating between trust and legitimacy in public attitudes towards legal authority. In E. Shockley, T. M. S. Neal, L. M. Pytlik-Zillig \& B. H. Bornstein (Eds.), Interdisciplinary perspectives on trust: Towards theoretical and methodological integration; interdisciplinary perspectives on trust: Towards theoretical and methodological integration (pp. 49-69, Chapter xiv, 222 Pages). Cham: Springer International Publishing.

Jacksonville Texas Police Department (2017). Citizen satisfaction survey. Retrieved from https://www.jacksonvilletx.org/DocumentCenter/View/76/Police-DepartmentCitizen-Satisfaction-Survey-PDF?bidId=

Jang, H., Joo, H., \& Zhao, J. (2010). Determinants of public confidence in police: An international perspective. Journal of Criminal Justice, 38(1), 57-68.

Jefferis, E., Butcher, F., \& Hanley, D. (2011). Measuring perceptions of police use of force. Police Practice \& Research, 12(1), 81-96.

Johnson, D., Maguire, E. R., \& Kuhns, J. B. (2014). Public perceptions of the legitimacy of the law and legal authorities: Evidence from the Caribbean. Law \& Society Review, 48(4), 947-978.

Johnson, R. R. (2015, July). What influences overall citizen satisfaction with the police? Public Agency Training Council, Legal and Liability Risk Management Institute E-newsletter. Retrieved from http://www.patc.com/weeklyarticles/print/2015_johnson_citizensatisfaction.pdf 


\section{CONFIDENCE IN LAW ENFORCEMENT}

Jones, J. M. (2015, June 19). In U.S., confidence in police lowest in 22 years. Gallup Analytics. Retrieved from http://news.gallup.com/poll/183704/confidence-policelowest-years.aspx

Jones, M., \& Rowe, M. (2015). Sixteen years on: Examining the role of diversity within contemporary policing. Policing: A Journal of Policy and Practice, 9(1), 2-4. http://policing.oxfordjournals.org.ezproxylocal.library.nova.edu/content/9

Keeling, D. G., \& Swartz, K. M. (2014, April). Louisville Metro Police citizens' attitude survey. Retrieved from https://www.louisvillepolice.org/ArchiveCenter/ViewFile/Item/71

Kennedy, B. (2014). Unraveling representative bureaucracy: A systematic analysis of the literature. Administration \& Society, 46(4), 395-421.

Kennedy, B. A., Butz, A. M., Lajevardi, N., \& Nanes, M. J. (2017). Race and representative bureaucracy in American policing. Cham. Switzerland: Palgrave MacMillan.

Kettering Police and Communication Center (2017). Citizen satisfaction survey results. Retrieved from https://storage.googleapis.com/proudcity/ketteringoh/uploads/2018/05/SurveyResults-2017.pdf

Kingsley, J. D. (1944). Representative bureaucracy: An interpretation of the British civil service. Yellow Springs: Antioch Press.

Kunzelman, M., \& Izaguirre, A. (2018, Mar. 27). Cops cleared in fatal shooting of Alton Sterling. PoliceOne. Retrieved from https://www.policeone.com/officershootings/articles/472762006-Cops-cleared-in-fatal-shooting-of-Alton-Sterling/

Kusow, A. M., Wilson, L. C., \& Martin, D. E. (1997). Determinants of citizen satisfaction with the police: The effects of residential location. Policing: An International Journal of Police Strategy and Management, 20(4), 655-664.

LaFraniere, S., \& Lehren, A. W. (2015, October 24). The disproportionate risks of driving while Black: An examination of traffic stops and arrests in Greensboro, N.C., uncovered wide racial differences in measure after measure of police conduct. New York Times. Retrieved from https://www.nytimes.com/2015/10/25/us/racial-disparity-traffic-stops-drivingblack.html

Lai, Y., \& Zhao, J. S. (2010). The impact of race/ethnicity, neighborhood context, and police/citizen interaction on residents' attitudes toward the police. Journal of Criminal Justice, 38(4), 685-692. 


\section{CONFIDENCE IN LAW ENFORCEMENT}

Lambert, J. (2016). Cultural diversity as a mechanism for innovation: Workplace diversity and the absorptive capacity framework. Journal of Organizational Culture, Communications and Conflict, 20, 68-77.

Lasley, J. R., Larson, J., Kelso, C., \& Brown, G. C. (2011). Assessing the long-term effects of officer race on police attitudes towards the community: A case for representative bureaucracy theory. Police Practice \& Research, 12(6), 474-491.

Lee, J. (2017). Of course the cops are racist: Procedural justice, the perception of racial profiling, and citizen satisfaction with law enforcement. Criminology, Criminal Justice, Law \& Society, 18(2), 80-92.

Legewie, J., and Fagan, J. (2016). Group threat, police officer diversity and the deadly use of force. Columbia Public Law Research Paper No. 14-512. Retrieved from https://papers.ssrn.com/sol3/papers.cfm?abstract_id=2778692

LEMAS (2013). See United States Department of Justice (USDOJ), infra.

Lemieux, F. (2014, December 17). Democratic policing: What it says about America today. The Conversation. Retrieved from https://theconversation.com/democraticpolicing-what-it-says-about-america-today-35066

Likert R. (1932). A Technique for the Measurement of Attitudes. Archives of Psychology, 140, 1-55.

Liou, K. T., \& Savage, E. G. (1996). Citizen perception of community policing impact. Public Administration Quarterly, 20(2), 173-179.

Lord, V. B., Kuhns, J. B., \& Friday, P. C. (2009). Small city community policing and citizen satisfaction. Policing: An International Journal of Police Strategies and Management, 32(4), 574-594.

Lowry, P. B., D’Arcy, J., Hammer, B., \& Moody, G. D. (2016). “Cargo Cult” science in traditional organization and information systems survey research: A case for using nontraditional methods of data collection, including Mechanical Turk and online panels. The Journal of Strategic Information Systems, 25(3), 232-240.

Ludlow, R. (2014, December 6). Kasich: Ohio must heal communities fractured by distrust of police. Columbus Dispatch. Retrieved from http://www.dispatch.com/content/stories/local/2014/12/05/Kasich_police.html

Lum, C., Johnson C., Nichols, J., Grieco, J., \& Wu, X. (2016, April). The Fairfax County community survey of the Fairfax County Police Department. Retrieved from http://cebcp.org/wp-content/evidence-based-policing/matrix-demonstrationproject/FCPDSurvey.pdf 


\section{CONFIDENCE IN LAW ENFORCEMENT}

MacCallum, R. C., Widaman, K. F., Preacher, K. J., \& Hong, S. (2001). Sample size in factor analysis: The role of model error. Multivariate Behavioral Research, 36(4), 611-637.

MacDonald, J., Stokes, R. J., Ridgeway, G., \& Riley, K. J. (2007). Race, neighbourhood context and perceptions of injustice by the police in Cincinnati. Urban Studies, 44(13), 2567-2585.

Machado, G. (2013, November). Community satisfaction survey: A study conducted for the Town of Dewitt Police Department. Retrieved from http://townofdewittpolice.com/uploads/Town_of_Dewitt_Community_Satisfactio n_Survey_2013.pdf

Madan, M. O. (Dec. 11, 2017). Video shows man being shot to death after dragging Broward Sheriff's deputy by the leg. Kansas City Star. Retrieved from https://www.kansascity.com/news/nation-world/article189126534.html

Mandan Tomorrow Committee (2017). Summary of 2017 community perceptions survey. Retrieved from https:/www.cityofmandan.com/vertical/sites/\%7B38C3EFDCF4D8-4D02-9E130987A081A7A4\%7D/uploads/2017_Survey_executive_summary_-_final.pdf

Manning, P. K. (2016). Democratic policing in a changing world. New York NY: Routledge/Taylor \& Francis Group.

Maslov, A. (2015). Measuring the performance of the police: The perspective of the public. Government of Canada, Public Safety Canada. Retrieved from https://www.publicsafety.gc.ca/cnt/rsrcs/pblctns/2015-r034/2015-r034-en.pdf

Mazerolle, L., Antrobus, E., Bennett, S., \& Tyler, T. R. (2013). Shaping citizen perceptions of police legitimacy: a randomized field trial of procedural justice. Criminology, 51, 33-63.

Mazerolle, L., Bennett, S., Davis, J., Sargeant, E., \& Manning, M. (2013). Legitimacy in policing: A systematic review. Campbell Systematic Reviews, 9(1), i-146.

McCluskey, J. D., McCluskey, C. P., \& Enriquez, R. (2008). A comparison of Latino and white citizen satisfaction with police. Journal of Criminal Justice, 36, 471-477.

McElvain, J. P., \& Kposowa, A. J. (2008). Policing officer characteristics and the likelihood of using deadly force. Criminal Justice and Behavior, 35(4), 505-521.

McGee, P., \& Fernandez, M. (2015, Aug. 11). Arlington, Tex., officer is fired in fatal shooting of Christian Taylor. The New York Times. Retrieved from https://www.nytimes.com/2015/08/12/us/arlington-tex-officer-is-fired-in-fatalshooting-of-christian-taylor.html 


\section{CONFIDENCE IN LAW ENFORCEMENT}

Milewski, T. D. (2014, September 12). How representative of the city's racial makeup is Madison's police force? The Capital Times. Retrieved from http://host.madison.com/ct/news/local/writers/todd-milewski/how-representativeof-the-city-s-racial-makeup-is-madison/article_3f6e8c06-39f5-11e4-8e82df98e8c9a2d8.html

Miller, J., \& Davis, R. C. (2008). Unpacking public attitudes to the police: Contrasting perceptions of misconduct with traditional measures of satisfaction. International Journal of Police Science \& Management, 10(1), 9-22.

Miller, J., Davis, R. C., Henderson, N. J., Markovic, J., \& Ortiz, C. (2005). Measuring influences on public opinion of the police using time series data: results of a pilot study. Police Quarterly, 8(3), 394-401.

Miller, T. I. (2018, February 1). Do Americans feel law enforcement has failed them? ASPA National Weblog. Retrieved from https://www.n-r-c.com/do-americansfeel-law-enforcement-has-failed-them $\% \mathrm{E} 2 \% 80 \% 8 \mathrm{~B} /$

Morabito, M., \& Shelley, T. O. (2015). Representative bureaucracy: Understanding the correlates of the lagging progress of diversity in policing. Race and Justice, 5(4), 330-355.

Morial, M. H. (2016, Oct 14). Advancing diversity in law enforcement. Philadelphia Tribune. Retrieved from http://www.phillytrib.com/advancing-diversity-in-lawenforcement/article_a9ef53bf-7b71-5b45-9d14-b4ba801b0dd1.html

Morin, R., \& Stepler, R. (2016). The racial confidence gap in police performance. Pew Research Center. Retrieved from http://assets.pewresearch.org/wpcontent/uploads/sites/3/2016/09/ST_2016.09.29_Police-Final.pdf

Morris, C. S. (2011). A cross-national study on public confidence in police. Northeastern University (Doctoral dissertation). Retrieved from https://repository.library.northeastern.edu/files/neu:1022/fulltext.pdf

Morton, D. R. (2018). Improving police transparency and accountability in violent encounters with African Americans. Journal of African American Studies, 1, 125138.

Mullinix, K. J., Leeper, T. J., Druckman, J. N., \& Freese, J. (2015). The generalizability of survey experiments. Journal of Experimental Political Science, 2(2), 109-138.

Mundform, D. J., Shaw, D. G., \& Ke, T. L. (2005). Minimum sample size recommendations for conducting factor analyses. International Journal of Testing, 5(2), 159-168.

Murphy, K. (2017). Challenging the 'invariance' thesis: Procedural justice policing and the moderating influence of trust on citizens' obligation to obey police. Journal of Experimental Criminology, 13, 429-437. 


\section{CONFIDENCE IN LAW ENFORCEMENT}

Murphy, K. and Cherney, A. (2012). Understanding Cooperation with Police in a Diverse Society. British Journal of Criminology, 52, 181-201.

Murphy, K., Cramer, R. J., Waymire, K. A., \& Barkworth, J. (2018). Police bias, social identity, and minority groups: A social psychological understanding of cooperation with police. Justice Quarterly, 35(6), 1105-1130.

Murphy, K., Mazerolle, L., \& Bennett, S. (2014). Promoting trust in police: findings from a randomized experimental field trial of procedural justice policing. Policing and Society, 24, 405-424.

Myrstol, B. A. (2011). Public perceptions of school resource officer (SRO) programs. Western Criminology Review, 12(3), 20-40.

Nadal, K. L., \& Davidoff, K. C. (2015). Perceptions of Police Scale (POPS): Measuring attitudes towards law enforcement and beliefs about police bias. Journal of Psychology and Behavioral Science, 3(2), 1-9.

Nadal, K. L., Davidoff, K. C., Allicock, N., Serpe, C. R., \& Erazo, T. (2017). Perceptions of police, racial profiling, and psychological outcomes: A mixed methodological study. Journal of Social Issues, 73(4), 808-830.

Natarajan, R. (2014, December 15). Racial profiling has destroyed public trust in police. Cops are exploiting our weak laws against it. Washington Post. Retrieved from https://www.washingtonpost.com/posteverything/wp/2014/12/15/racial-profilinghas-destroyed-public-trust-in-police-cops-are-exploiting-our-weak-laws-againstit/?utm_term=.5409f49f9f4a

National Institute of Justice (2013, January 10) (“NIJ, 2013”). Race, trust and police legitimacy. Retrieved from http://www.nij.gov/topics/lawenforcement/legitimacy/pages/welcome.aspx

National Institute of Justice (U.S.), \& United States. (2002) (“NIJ, 2002”). Satisfaction with police: What matters? Washington, DC: U.S. Dept. of Justice, Office of Justice Programs, National Institute of Justice. Retrieved from https://www.ncjrs.gov/pdffiles1/nij/194077.pdf

National Police Research Platform (2018) (“NPRP, 2018”). Current state of knowledge on American policing. Retrieved from http://uicclj.squarespace.com/current-stateof-knowledge/

National Research Center, Inc. (2006). The City of Morgantown, West Virginia: Report of normative comparisons 2006. Retrieved from https://www.morgantownwv.gov/DocumentCenter/View/520/Normative-Reporton-Survey-Results-PDF 


\section{CONFIDENCE IN LAW ENFORCEMENT}

National Research Center, Inc. (2013a). The national citizen survey: City of Sevierville, TN 2013: Benchmark report. Retrieved from http://seviervilletn.org/index.php/administration/73-citizen-survey-benchmarkreport/file.html

National Research Center, Inc. (2013b). The national citizen survey: Park City, UT:

Technical appendices 2013. Retrieved from https://www.parkcity.org/home/showdocument?id=13254

National Research Center, Inc. (2015). The national citizen survey, Brownsburg, IN: Technical appendices. Retrieved from http://www.brownsburgsentinel.com/ARCHIVE/2016_01_31/2015_Brownsburg Survey_Results/5-2015_Survey_Technical_appendix.pdf

National Research Center, Inc. (2016). Edmond citizen satisfaction survey results 2016. Retrieved from https://finance.baltimorecity.gov/sites/default/files/citizensurvey.pdf

National Research Center, Inc. (2017a). The national citizen survey, Milford, DE: Technical appendices 2017. Retrieved from https://www.cityofmilford.com/DocumentCenter/View/2464/National-CitizensSurvey-Report-3-2017?bidId=

National Research Center, Inc. (2017b). The national citizen survey: Rio Rancho, NM: Community livability report. Retrieved from https://rnm.gov/DocumentCenter/View/70496/The-NCS-Community-LivabilityReport-Rio-Rancho-Final-2017?bidId=

National Research Center, Inc. (2017c). National citizen survey: Sioux Falls, SD: Community livability report 2017. Retrieved from file://C:/Users/Chuck\%20MacLean/Downloads/Livability-Report-2017.pdf

Nelson, S. C. (2014, Nov. 24). Tamir Rice, 12, shot dead by Cleveland police after brandishing fake gun. Huffington Post. Retrieved from https://www.huffingtonpost.co.uk/2014/11/24/tamir-rice-12-shot-dead-clevelandpolice-brandishing-fake-

gun_n_6209970.html?guccounter=1\&guce_referrer_us=aHR0cHM6Ly93d3cuZ2 9vZ2x1LmNvbS8\&guce_referrer_cs=mhNWc6wJULuH5R4Qxehvlw

Newport, F. (2014, August 20). Gallup review: Black and White attitudes toward the police. Retrieved from http://www.gallup.com/poll/175088/gallup-review-blackwhite-attitudes-toward-police.aspx

Newport, F. (2016, July 8). Public opinion context: Americans, race and police. Gallup Analytics. Retrieved from http://news.gallup.com/opinion/pollingmatters/193586/public-opinion-context-americans-race-police.aspx 


\section{CONFIDENCE IN LAW ENFORCEMENT}

Nicholson-Crotty, S., Nicholson-Crotty, J., \& Fernandez, S. (2017). Will more Black cops matter? Officer race and police-involved homicides of Black citizens. Public Administration Review, 77(2), 206-216.

NIJ (2002, 2013). See National Institute of Justice (2002, 2013), supra.

Nix, J., Wolfe, S. E., Rojek, J., \& Kaminski, R. J. (2015). Trust in the police: The influence of procedural justice and perceived collective efficacy. Crime \& Delinquency, 61(4). 610-640.

Norman, J. (2017). Confidence in police back at historical average. Gallup Analytics. Retrieved from http://news.gallup.com/poll/213869/confidence-police-backhistorical-average.aspx

Nunnally J. C. (1978). Psychometric theory (2nd ed.). New York, NY: McGraw-Hill.

O'Neill, M. O. (2015). The case for the acceptable 'other': The impact of partnerships, PCSOs, and neighbourhood policing on diversity in policing. Policing: An International Journal of Police Strategies \& Management, 89(1): 77-88.

O'Shea, T. C. (2000). The political dimension of community policing: Belief congruence between police and citizens. Police Quarterly, 3(4), 389-412.

OpenDataSoft. US Zip Code Latitude and Longitude. Retrieved from https://public.opendatasoft.com/explore/dataset/us-zip-code-latitude-andlongitude/table/

Ozkan, M. (2016). Citizen satisfaction with police: A pillar of law enforcement governance. International Journal of Humanities and Social Science Invention, 5(4), 6-11.

Ozkan, T., Worrall, J. L., \& Piquero, A. R. (2016). Does minority representation in police agencies reduce assaults on the police? American Journal of Criminal Justice, 41(3), 402-423.

Paolacci, G., Chandler, J., \& Ipeirotis, P. G. (2010). Running experiments on Amazon Mechanical Turk. Judgment and Decision Making, 5(5), 411.

Paoline, E. A., Gau, J. M., \& Terrill, W. (2018). Race and the police use of force encounter in the United States. British Journal of Criminology, 58(1), 54-74.

Pearson, K. (1895). Notes on regression and inheritance in the case of two parents. Proceedings of the Royal Society of London, 58, 240-242.

Pearson, R. H. \& Mundform, D. J. (2010). Recommended sample size for conducting exploratory factor analysis on dichotomous data. Journal of Modern Applied Statistical Methods, 9(2), 359-368. 


\section{CONFIDENCE IN LAW ENFORCEMENT}

Peck, J. H. (2015). Minority perceptions of the police: A state-of-the-art review. Policing, 38(1), 173-203.

Perkins, M. (2016). Modelling public confidence of the police: How perceptions of the police differ between neighborhoods in a city. Police Practice \& Research, 17(2), 113-125.

Peterson, S., Peterson, A., Bartholomay, A., Huckaby, W., \& MartinRogers, N. (2016, December). City of Minneapolis 2016 resident survey. Retrieved from http://www.minneapolismn.gov/www/groups/public/@ citycoordinator/documents /webcontent/wcmsp-191136.pdf

Pew Research Center/USA Today (2014, August 25). Few say police forces nationally do well in treating races equally: Most have at least "fair amount" of confidence in local police. Retrieved from http://www.people-press.org/files/2014/08/8-25-14Police-and-Race-Release.pdf

Philpott, D. (2016). Critical government documents on law and order. Lanham MD: Bernan Press.

Piatkowski, S. J. (2015). Immigrants' confidence in police: Do county-level characteristics matter? International Journal of Comparative and Applied Criminal Justice, 39(1), 1-30.

Pinal County (2015). Pinal County citizen satisfaction survey 2014-2015. Retrieved from http://www.pinalcountyaz.gov/PCPM/Documents/CitizenSatisfactionSurvey/Pinal $\% 20$ Citizen $\% 20$ Satisfaction\%20Survey\%2020142015\%20Report\%20Final\%206-29-2015.pdf

Pino, N., \& Wiatrowski, M. D. (eds.) (2016). Democratic policing in transitional and developing countries. New York NY: Routledge/Taylor \& Francis Group.

Posick, C., Rocque, M., McDevitt, J. (2013). One scale fits all? Assessing racial differences in the measurement of attitudes toward the police. Race and Justice, 3(3), 190-209.

President's Task Force on $21^{\text {st }}$ Century Policing (2015, May). Final report. Retrieved from https://cops.usdoj.gov/pdf/taskforce/taskforce_finalreport.pdf

Pytlik-Zillig, L. M., Walther, J., \& Kawamoto, J. (2017). Taking charge 2017: Satisfaction of residents of Lincoln, Nebraska. Retrieved from http://lincoln.ne.gov/city/mayor/takingcharge/pdf/taking-charge-2017-finalreport.pdf

Rahr, S., \& Rice, S. K. (2015, April). From warriors to guardians: Recommitting American police culture to democratic ideals. New Perspectives in Policing. Harvard Kennedy School. Retrieved from https://www.ncjrs.gov/pdffiles1/nij/248654.pdf 


\section{CONFIDENCE IN LAW ENFORCEMENT}

Rastogi, A., Johnson, T. D., Hoettel, E. M., \& Drewerym M. P. (2011). 2010 Census briefs: The black population: 2010. U.S. Department of Commerce, U.S. Census Bureau, Economics and Statistics Administration. Retrieved from https://www.census.gov/prod/cen2010/briefs/c2010br-06.pdf

Ray, J. M. (2012). Toward a more democratic American policing model: Understanding community oriented policing as a practical application of deliberative democratic theory (Doctoral dissertation). Available from ProQuest Dissertations \& Theses Global (1272130017).

Reaves, B. A. (2011). Census of state and local law enforcement agencies, 2008. U.S. Department of Justice, Office of Justice Programs, Bureau of Justice Statistics. Retrieved from https://www.bjs.gov/content/pub/pdf/csllea08.pdf

Reaves, B. A. (2015, May). Local police departments, 2013: Personnel, policies, and practices. U.S. Department of Justice, Office of Justice Programs, Bureau of Justice Statistics. Retrieved from https://www.bjs.gov/content/pub/pdf/lpd13ppp.pdf

Redfern, J. S. (2014). Nationwide survey of attitudes of law enforcement personnel towards transgender individuals. Journal of Law Enforcement, 4(1), 1-24.

Regulus, T. A., Taylor, R. J., \& Jackson, J. S. (2001). The structure of black Americans' attitudes toward the police. African American Research Perspectives, 7, 185-206. Retrieved from http://www.rcgd.isr.umich.edu/prba/perspectives/winter2001/tregulus2.pdf

Reisig, M. D., \& Chandek, M. S. (2001). The effects of expectancy disconfirmation on outcome satisfaction in police-citizen encounters. Policing: An International Journal of Police Strategies and Management, 21(1), 88-99.

Reisig, M. D., \& Parks, R. B. (2000). Experience, quality of life, and neighborhood context: A hierarchical analysis of satisfaction with the police. Justice Quarterly, 17(3), 607-630.

Reisig, M. D., \& Parks, R. B. (2002). Satisfaction with police: What matters? U.S. Department of Justice, Office of Justice Programs, National Institute of Justice. Retrieved from https://www.ncjrs.gov/pdffiles1/nij/194077.pdf

Riccucci, N. M., Van Ryzin, G.,G., \& Lavena, C. F. (2014). Representative bureaucracy in policing: Does it increase perceived legitimacy? Journal of Public Administration Research and Theory, 24(3), 537-551.

Richard Caplan \& Associates (2009). City of Hailey, Idaho: Citizen satisfaction survey. Retrieved from https://www.haileycityhall.org/Announcements/Hailey\%20Citizen\%20Survey\%2 0Report\%20February\%2027\%202009.pdf 


\section{CONFIDENCE IN LAW ENFORCEMENT}

Roberson, Q. M. (2019). Diversity in the workplace: A review, synthesis, and future research agenda. Annual Review of Organizational Psychology and Organizational Behavior, 6, 69-88.

Roberson, Q. M., Ryan, A. M., \& Ragins, B. R. (2017). The evolution and future of diversity at work. Journal of Applied Psychology, 102(3), 483-499.

Rock, D., \& Grant, H. (2016). Why diverse teams are smarter. Harvard Business Review Online (HBR.org). Retrieved from https://leadersforgood.net/wpcontent/uploads/2016/01/H038YZ-PDF-ENG.pdf

Romain, D. M., \& Hassell, K. D. (2014). An exploratory examination of the sources of socialization influencing juvenile perceptions of the police. International Journal of Police Science and Management, 16(1), 36-51.

Rosenbaum, D. P., Escamilla, J., Enciso, G., Christoff, T., \& Hartnett, S. M. (n.d.). Results from the Police-Community Interaction (PCI) Survey. Retrieved from http://static1.1.sqspcdn.com/static/f/733761/26521932/1441740276970/PCI+Web +Report.pdf?token=wDXqLtbVlryxvI7acPx2qizovCE\%3D

Rosenbaum, D. P., Lawrence, D. S., Hartnett, S. M., McDevitt, J., \& Posick, C. (2015). Measuring procedural justice and legitimacy at the local level: The policecommunity interaction survey. Journal of Experimental Criminology, 11(3), 335366.

Rosenbaum, D. P., Schuck, A. M., Costello, S. K., Hawkins, D. F., \& Ring, M. K. (2005). Attitudes toward the police: the effects of direct and vicarious experience. Police Quarterly, 8(3), 343-365.

Rosenbaum, D. P., Schuck, A. M., Graziano, L. M., \& Stephens, C. D. (2007, November 25). Measuring police and community performance using web-based surveys: Findings from the Chicago Internet Project, Final Report. Retrieved from https://www.ncjrs.gov/pdffiles 1/nij/grants/221076.pdf

Rosenbaum, D. P., Schuck, A. M., Lawrence, D., \& Hartnett, S. (2011, February). Community-based indicators of police performance: Introducing the platform's public satisfaction survey. National Police Research Platform. Retrieved from https://www.nationallawenforcementplatform.org/wpcontent/uploads/2017/05/PublicSatisfaction.pdf

Ruffin, R. D. (2016). Examining minority perceptions of police behavior (Order No. 10195947). Available from ProQuest Dissertations \& Theses Global. (1864697005).

Ruiz, R. R. (2017, Sept. 12). Baltimore officers will face no federal charges in death of Freddie Gray. The New York Times. Retrieved from https://www.nytimes.com/2017/09/12/us/freddie-gray-baltimore-police-federalcharges.html 


\section{CONFIDENCE IN LAW ENFORCEMENT}

Salvatore, C., Markowitz, M., \& Kelly, C. E. (2013). Assessing public confidence in the criminal justice system. International Social Science Review, 88(1/2), 3-16.

Sampaio, J. O., De-Losso, R., Cunha, L. G., \& de Pieri, R. G. (2015). Does the concern about local crime affect trust in the police? Working Papers, Department of Economics 2015_19, University of São Paulo (FEA-USP). Retrieved from https://ideas.repec.org/p/spa/wpaper/2015wpecon19.html

Sargeant, E. (2017). Policing and collective efficacy: The relative importance of police effectiveness, procedural justice and the obligation to obey police. Policing \& Society, 27(8), 927-940.

Savolainen, J. (2019, March 25). Email correspondence with Director of National Archive of Criminal Justice Data, Inter-University Consortium for Political and Social Research (on file with author).

Schafer, J. A., Huebner, B. M., \& Bynum, T. S. (2003). Citizen perceptions of police services: Race, neighborhood context, and community policing. Police Quarterly, 6(4), 440-468.

Schuck, A.M. (2014). Female representation in law enforcement: The influence of screening, unions, incentives, community policing, CALEA, and size. Police Quarterly, i(1), 54-78.

Schuck, A. M., \& Rabe-Hemp, C. (2016). Citizen complaints and gender diversity in police organisations. Policing \& Society, 26(8), 859-874.

Schuck, A. M., \& Rosenbaum, D. P. (2005). Global and neighborhood attitudes toward the police: Differentiation by race, ethnicity and type of contact. Journal of Quantitative Criminology, 21(4), 391-418.

Schuck, A. M., Rosenbaum, D. P., \& Hawkins, D. F. (2008, December). The influence of race/ethnicity, social class, and neighborhood context on residents' attitudes toward the police. Police Quarterly, 11(4), 496-519.

Schulenberg, J. L., Chenier, A., Buffone, S., \& Wojciechowski, C. (2017). An application of procedural justice to stakeholder perspectives: Examining police legitimacy and public trust in police complaints systems. Policing \& Society, 27(7), 779796.

Seattle Police Department (2018, August). June 2018 service quality update. Retrieved from https://www.seattle.gov/Documents/Departments/Police/Publications/CustomerSu rveyReportJune2018Final.pdf

Sekhon, N. (2017). Blue on Black: An empirical assessment of police shootings. American Criminal Law Review, 54, 189-232. 


\section{CONFIDENCE IN LAW ENFORCEMENT}

Shelley, T. O., Hogan, M. J., Unnithan, N. P., \& Stretesky, P. B. (2013). Public opinion and satisfaction with state law enforcement. Policing: An International Journal of Police Strategies and Management, 36(3), 526-542.

Sherman, L. W. (2001). Trust and confidence in criminal justice. Retrieved from https://www.ncjrs.gov/pdffiles 1/nij/189106-1.pdf

Sherman, L. W. (2002). Trust and Confidence in Criminal Justice. National Institute of Justice Journal, 248, 22-31.

Shjarback, J., Decker, S., Rojek, J. J., \& Brunson, R. K. (2017). Minority representation in policing and racial profiling. Policing: An International Journal of Police Strategies and Management, 40(4), 748-767.

Shjarback, J. A., \& White, M. D. (2016). Departmental professionalism and its impact on indicators of violence in police-citizen encounters. Police Quarterly, 19(1), 3262.

Shusta, R. M., Levine, D. R., Wong, H. Z., Olson, A. T., \& Harris, P. R. (2014). Multicultural law enforcement: Strategies for peacekeeping in a diverse society, 6th ed. New Jersey: Pearson Education, Inc./Prentice Hall.

Simmons, A. D., \& Bobo, L. D. (2015). Can non-full-probability internet surveys yield useful data? A comparison with full-probability face-to-face surveys in the domain of race and social inequality attitudes. Sociological Methodology, 45(1), 357-387.

Skogan, W. G. (2005). Citizen satisfaction with police encounters. Police Quarterly, 8(3), 298-321.

Skogan, W. G. (2009). Concern about crime and confidence in the police: Reassurance or accountability? Police Quarterly, 12(3), 301-318.

Slobogin, C. (2014). Panvasive surveillance, political process theory, and the nondelegation doctrine. Georgetown Law Journal, 102, 1721-1776.

Smith, B. W. (2005). Ethno-racial political transition and citizen satisfaction with police. Policing: An International Journal of Police Strategies \& Management, 28(2), 242-254.

Smith, M. (2018, Oct. 9). An officer is guilty of murder. On trial next: A police "code of silence." The New York Times. Retrieved from https://www.nytimes.com/2018/10/09/us/laquan-mcdonald-chicago-police.html 


\section{CONFIDENCE IN LAW ENFORCEMENT}

Smith, S. K., Steadman, G. W., Minton, T. D., \& Townsend, M. (1999). Criminal victimization and perceptions of community safety in 12 cities, 1998. U.S. Department of Justice, Bureau of Justice Statistics, Office of Community Oriented Policing Services. Retrieved from https://www.bjs.gov/content/pub/pdf/cvpcs98.pdf

Solakoglu, O. (2016). Trust in police: A comparative study of Belgium and The Netherlands. International Journal of Criminal Justice Sciences, 11(1), 45-56.

Sousa, W. H., Meithe, T. D., \& Sakiyama, M. (2018). Inconsistencies in public opinion of body-worn cameras on police: Transparency, trust, and improved police-citizen relationships. Policing: A Journal of Policy \& Practice, 12(1), 100-108.

Statistical Package for the Social Sciences, version 25 ("SPSS-25”) (2019). International Business Machines ("IBM").

Stultz, B. J., Parker, K. F., \& Lane, E. C. (2010). A spatial and contextual analysis of policing: Examining Black, white and Hispanic stop rates. Journal of Crime and Justice, 33(1), 1-36.

Sullivan, J., Tate, J., \& Jenkins, J. (2018, May 7). Fatal policing shootings of unarmed people have significantly declined, experts say. The Washington Post. Retrieved from https://www.washingtonpost.com/investigations/fatal-police-shootings-ofunarmed-people-have-significantly-declined-experts-say/2018/05/03/d5eab3744349-11e8-8569-26fda6b404c7_story.html?utm_term=.d46f1074c6ab

Sun, I. Y., \& Payne, B. K. (2004, October). Racial differences in resolving conflicts: A comparison between Black and white officers. Crime \& Delinquency, 50(4), 516541.

Sun, I. Y., Wu, Y., Van Craen, M., \& Hsu, K. K. (2018). Internal procedural justice, moral alignment, and external procedural justice in democratic policing. Police Quarterly, 21(3), 387-412.

Sunshine, J., \& Tyler, T. (2003). The role of procedural justice and legitimacy in shaping public support of policing. Law and Society Review, 37(3), 513-548.

Swaine, J. (2016, Nov. 30). Keith Scott shooting: No charges to be file against Charlotte police officer. The Guardian. Retrieved from https://www.theguardian.com/usnews/2016/nov/30/keith-scott-shooting-no-charges

Tabachnick, B. G., \& Fidell, L. S. (1983). Using multivariate statistics. Cambridge MA: Harper \& Row Publishers.

Tankebe, J. (2010). Public confidence in the police: Testing the effects of public experiences of police corruption in Ghana. The British Journal of Criminology, 50(2), 296-319. 


\section{CONFIDENCE IN LAW ENFORCEMENT}

Tankebe, J. (2013). Viewing things differently: The dimensions of public perceptions of police legitimacy. Criminology, 51(1), 103-135.

Tankebe, J., Reisig, M. D., \& Wang, X. (2016). A multidimensional model of police legitimacy: A cross-cultural assessment. Law and Human Behavior, 40(1), 11-22.

Taylor, R. B., \& Lawton, B. A. (2012). An integrated contextual model of confidence in local police. Police Quarterly, 15(4), 414-445.

Taylor, R. B., Wyant, B. R., \& Lockwood, B. (2015). Variable links within perceived police legitimacy? Fairness and effectiveness across races and places. Social Science Research, 49, 234-248.

Terrill, W., \& Paoline, E. A. (2015). Citizen complaints as threats to police legitimacy: The role of officers' occupational attitudes. Journal of Contemporary Criminal Justice, 31(2), 192-211.

The Research Bureau (2011, August). NESPMP citizen satisfaction survey: Cross comparison results summary. Retrieved from https://www.townofpeterborough.com/vertical/sites/\%7B792D537E-D69C-464A80FB790917F72F17\%7D/uploads/NESPMP_Survey_Comparison_Results_2011.pdf

Theobald, N. A., \& Haider-Markel, D. (2009). Race, bureaucracy, and symbolic representation: Interactions between citizens and police. Journal of Public Administration Research and Theory, 19(2), 409-426.

Thomas, M. O., \& Burns, P. F. (2005). Repairing the divide. Journal of Ethnicity in Criminal Justice, 3(1-2), 71-90.

Tomaskovic-Devey, D., \& Warren, P. (2009). Explaining and eliminating racial profiling. Retrieved from http://contexts.org/articles/explaining-and-eliminatingracial-profiling/

Town of Bennington (2016). Citizen survey 2016. Retrieved from http://benningtonvt.org/wp-content/uploads/2012/11/2016-Citizen-SurveyPresentation-v3.pdf

Trochmann, M. B., \& Gover, A. (2016). Measuring the impact of police representativeness on communities. Policing: An International journal of Police Strategies \& Management, 39(4), 773-790.

Tyler, T. R. (2002). A national survey for monitoring police legitimacy. Justice Research and Policy, 4, 71-86.

Tyler, T. R. (2004). Enhancing police legitimacy. The Annals of the American Academy of Political and Social Science, 593(1), 84-99. 


\section{CONFIDENCE IN LAW ENFORCEMENT}

Tyler, T. R. (2005). Policing in Black and White: Ethnic group differences in trust and confidence in the police. Police Quarterly, 8(3), 322-342.

Tyler, T. R. (2006). Psychological perspectives on legitimacy and legitimation. Annual Review of Psychology, 57, 375-400.

Tyler, T. R., Goff, P. A., \& MacCoun, R. J. (2015). The impact of psychological science on policing in the United States: Procedural justice, legitimacy, and effective law enforcement. Psychological Science in the Public Interest, 16(3), 75-109.

Tyler, T. R., \& Huo, Y. J. (2002). Trust in the law: Encouraging public cooperation with the police and courts. New York NY: Russell Sage Foundation.

Tyler, T. R., \& Jackson, J. (2014). Popular legitimacy and the exercise of legal authority: Motivating compliance, cooperation and engagement. Psychology, Public Policy, and Law, 20, 78-95.

United States Census Bureau (2010) (“Census, 2010”). Census 2010. Retrieved from http://www.census.gov/2010census/

United States Census Bureau (2013) (“Census, 2013”). Population Estimates: Vintage 2013. Retrieved from http://www.census.gov/popest/data/counties/totals/2013/

United States Department of Justice (2015, Mar. 4) (“USDOJ, 2015”). Department of Justice report regarding the criminal investigation into the shooting death of Michael Brown by Ferguson, Missouri police officer Darren Wilson. Retrieved from https://www.justice.gov/sites/default/files/opa/press-

releases/attachments/2015/03/04/doj_report_on_shooting_of_michael_brown_1.p df

United States Department of Justice, Community Relations Service (2010) ("CRS, 2010"). Police use of force: Addressing community racial tensions. Retrieved from https://www.justice.gov/archive/crs/pubs/policeuseofforce092003.pdf

United States Department of Justice, Office of Justice Programs, Bureau of Justice Statistics ("LEMAS, 2007"). Law enforcement management and administrative statistics (LEMAS) 2007. Retrieved from https://www.icpsr.umich.edu/icpsrweb/RCMD/studies/36164

United States Department of Justice, Office of Justice Programs, Bureau of Justice Statistics ("LEMAS, 2013"). Law enforcement management and administrative statistics (LEMAS) 2013. Retrieved from https://www.icpsr.umich.edu/icpsrweb/RCMD/studies/36164

United States Department of Justice, Office of Justice Programs, Bureau of Justice Statistics ("LEMAS Codebook, 2013"). Law enforcement management and administrative statistics (LEMAS) 2013 Codebook. Retrieved from https://www.icpsr.umich.edu/icpsrweb/NACJD/studies/36164 


\section{CONFIDENCE IN LAW ENFORCEMENT}

United States Department of Justice, Office of Justice Programs, Bureau of Justice Statistics ("LEMAS, 2016a"). Law enforcement management and administrative statistics (LEMAS) 2016: 2016 LEMAS Instrument. Retrieved from https://www.icpsr.umich.edu/icpsrweb/RCMD/studies/36164

United States Department of Justice, Office of Justice Programs, Bureau of Justice Statistics ("LEMAS, 2016b"). Law enforcement management and administrative statistics, overview: 2016 LEMAS core survey schedule. Retrieved from https://bjslecs.org/lemas2016

USDOJ (2015). See United States Department of Justice (2015), supra.

Vann, M., \& Ortiz, E. (2017, Dec. 7). Walter Scott shooting: Michael Slager, ex-officer, sentenced to 20 years in prison. NBC News. Retrieved from

https://www.nbcnews.com/storyline/walter-scott-shooting/walter-scott-shootingmichael-slager-ex-officer-sentenced-20-years-n825006

Village of North Palm Beach (2008-09). Citizen satisfaction survey results. Retrieved from http://www.village-npb.org/DocumentCenter/View/378/CitizenSatisfaction-Survey-Results-PDF?bidId=

Warren, P. Y. (2010). The continuing significance of race: An analysis across two levels of policing. Social Science Quarterly (Wiley-Blackwell), 91(4), 1025-1042.

Warwick Police Department (2017). 2017 annual satisfaction survey. Retrieved from https://www.warwickpd.org/index.php/surveys-reports/wpd-survey

Webb, V. J., \& Marshall, C. E. (1995). The relative importance of race and ethnicity on citizen attitudes toward the police (no. 2). American Journal of Police, 14, 45-66.

Weisel, D. (1999, October). Conducting community surveys: A practical guide for law enforcement agencies. Retrieved from https://www.bjs.gov/content/pub/pdf/ccspglea.pdf

Weitzer, R. (2002). Incidents of police misconduct and public opinion. Journal of Criminal Justice, 30(5), 397-408.

Weitzer, R. (2015, January 20). Diversity among police officers is key, but it won't solve the problems with policing. The Guardian. Retrieved from https://www.theguardian.com/commentisfree/2015/jan/20/diversity-amongpolice-officers-is-key-but-it-wont-solve-the-problems-with-policing

Weitzer, R., \& Hasisi, B. (2008). Does ethnic composition make a difference? Citizens' assessments of Arab police officers in Israel. Policing \& Society, 18(4), 362-376.

Weitzer, R., \& Tuch, S. A. (2004). Race and perceptions of police misconduct. Social Problems, 51(3), 305-325. 


\section{CONFIDENCE IN LAW ENFORCEMENT}

Weitzer, R., \& Tuch, S. A. (2005). Determinants of public satisfaction with the police. Police Quarterly, 8(3), 279-297.

Weitzer, R., Tuch, S. A., \& Skogan, W. G. (2008). Police-community relations in a majority-Black city. Journal of Research in Crime and Delinquency, 45(4), 398428.

Wiatrowski, M. D., \& Goldstone, J. A. (2010). The ballot and the badge: Democratic policing. Journal of Democracy, 21(2), 79-92.

Willow, M. W., \& Cohen, P. N. (2017, January). Black and Hispanic representation in policing: Organizational and local labor market context. Paper presented the 2017 meetings of the American Sociological Association. Retrieved from https://osf.io/preprints/socarxiv/5zykt/

Wilson, C. P., Wilson, S. A., \& Gwann, M. (2016). Identifying barriers to diversity in law enforcement agencies. Journal of Ethnicity in Criminal Justice, 14(4), 231-253.

Wolfe, S. E., Nix, J., Kaminski, R., \& Rojek, J. (2016). Is the effect of procedural justice on police legitimacy invariant? Testing the generality of procedural justice and competing antecedents of legitimacy. Journal of Quantitative Criminology, 32(2), 253-282.

Woods, E. E. (2015, May). Driving while Black: Racial profiling and traffic stops. Ohio State Journal of Criminal Law. Retrieved from http://moritzlaw.osu.edu/students/groups/osjcl/amici-blog/driving-while-blackracial-profiling-and-traffic-stops/

Worrall, J. L. (1999). Public perceptions of police efficacy and image: The "fuzziness" of support for the police. American Journal of Criminal Justice, 24(1), 47-66.

WPA Intelligence (2018). New Orleans Crime Coalition citizen satisfaction survey. Retrieved from http://crimecoalitionnola.com/wpcontent/uploads/2018/09/NOCC_Citizen-SatisfactionSurvey_September2018_180918.pdf

Wu, Y. (2010). College students' evaluation of police performance: a comparison of Chinese and Americans. Journal of Criminal Justice, 38, 773-780.

Wu, Y. (2014). Race/ethnicity and perceptions of the police: A comparison of white, Black, Asian and Hispanic Americans. Policing \& Society, 24(2), 135-157.

Wu, Y., Sun, I., \& Smith, B. W. (2011). Race, immigration, and policing: Chinese immigrants' satisfaction with police. Justice Quarterly, 28(5), 745-775.

Wu, Y., Sun, I., Triplett, R. A. (2009). Race, class, or neighborhood context: Which matters more in measuring satisfaction with police? Justice Quarterly, 26(1), 125157. 


\section{CONFIDENCE IN LAW ENFORCEMENT}

Zhao, J. S., Lai, Y-L, Ren, L., \& Lawton, B. (2015). The impact of race/ethnicity and quality-of-life policing on public attitudes toward racially biased policing and traffic stops. Crime and Delinquency, 61(3), 350-374. 
CONFIDENCE IN LAW ENFORCEMENT

Appendix 
CONFIDENCE IN LAW ENFORCEMENT

\section{Appendix}

Qualtrics Survey Instrument:

"Attitudes About Law Enforcement in Your Community"

Attitudes About Law Enforcement in Your Community 
CONFIDENCE IN LAW ENFORCEMENT

Q10 INFORMED CONSENT ADVISORY

NOTE: ONLY ONE SURVEY RESPONSE PER HOUSEHOLD

NSU-Florida

Nova Southeastern University

Abraham S. Fischler College of Education

School of Criminal Justice

3301 College Avenue

Fort Lauderdale, Florida 33314-7796

(954) 262-8500

800-986-3223, extension 28500

education.nova.edu

Participant Letter for Anonymous Surveys

Nova Southeastern University Consent to be in a Research Study Entitled:

African-American Confidence in Law Enforcement When African-Americans are Underrepresented on the Force: An Exploratory Study

Who is doing this research study? This person doing this study is Charles E. MacLean with the Abraham S. Fischler College of Education's School of Criminal Justice. Principal Investigatory MacLean will be assisted by faculty advisor, Dr. Marcelo Castro.

Why are you asking me to be in this research study?

You are being asked to take part in this research study because you are an AfricanAmerican adult male, who has expressed interest in completing surveys using Amazon Mechanical Turk ("MTurk").

Why is this research being done? The purpose of this study is to assess the impact of the racial makeup of law enforcement agencies on minority civilian attitudes toward those agencies.

What will I be doing if I agree to be in this research study? You will be taking a one-time, anonymous survey. The survey will take approximately five-to-ten minutes to complete.

Are there possible risks and discomforts to me?

This research study involves minimal risk to you. To the best of our knowledge, the things you will be doing have no more risk of harm than you would have in everyday life.

What happens if I do not want to be in this research study?

You can decide not to participate in this research and it will not be held against you. You can exit the survey at any time. 


\section{Will it cost me anything? Will I get paid for being in the study?}

There is no cost for participation in this study. Participation is voluntary and you will be paid by MTurk for your participation in the survey based on AMT's policies and procedures.

How will you keep my information private? - Your responses are anonymous. Information we learn about you in this research study will be handled in a confidential manner, within the limits of the law. All information that you provide will be kept in strict confidence. It is important to us to protect your privacy. All participants' answers are combined and presented in the form of summary statistics, such as in tables and graphs. If you decline to answer a question or item or any portion of the interview, data from other questions or items you have answered may be used in these summary statistics. Although the researcher will make every effort to protect your confidentiality and will not even collect your name, the researcher may be obliged to provide survey responses pursuant to a court order or subpoena and the researcher may voluntarily report information about suspected or known sexual, physical, or other abuse of a child or elderly person, or a participant's threat of violence to self or others. These data will be available to the researcher, the Institutional Review Board, and other representatives of this institution. All confidential data will be kept securely in a locked facility and a single password-protected computer. All data will be kept for 36 months from the end of the study and destroyed after that time by shredding all paper copies and purging all digital files.

Who can I talk to about the study? If you have questions, you can contact Principal Investigator Charles E. MacLean at 507-459-9241 or Dr. Marcelo Castro (faculty advisor) at 954-262-7808. If you have questions about the study but want to talk to someone else who is not a part of the study, you can call the Nova Southeastern University Institutional Review Board (IRB) at (954) 262-5369 or toll free at 1-866-4990790 or email at IRB@nova.edu.

Do you understand and do you want to be in the study? If you have read the above information and voluntarily wish to participate in this research study and complete this brief online survey today, please select the ACCEPT button below after which you will immediately begin that survey. If you wish to decline this invitation to participate in this survey, please select the Decline button below.

\section{ACCEPT (1)}

DECLINE (2) 


\section{CONFIDENCE IN LAW ENFORCEMENT}

Q1 Indicate your age range in years.

18-29 years old (1)

30-49 years old (2)

50 years old or above (3)

Q2 Indicate your sex.

Male (1)

Female (2)

Other or Withheld (3)

Q3 Indicate your predominate race.

African-American or Black (1)

Not African-American or Black (2)

Other or Withheld (3)

Q4 Indicate whether you are Hispanic.

Hispanic (1)

Not Hispanic (2)

Other or Withheld (3)

Q9 Please type the zipcode of your residence in the box below. 
CONFIDENCE IN LAW ENFORCEMENT 
Q5 Rate whether you agree or disagree with each of the following statements about the law enforcement officers and agencies serving the community in which you live.
Agree (3)
Neither Agree nor
Disagree (2)
Disagree (1)
The racial makeup of
the officers is
consistent with the
racial makeup of the
people in my
community. (1)
The officers are
trustworthy. (2)
The officers are often dishonest. (3)
The officers are usually honest. (4)

The officers usually act within the law.

I am proud of the officers who serve my community. (6)

I have confidence in the officers who serve my community. (7)

The officers treat everyone with respect. (8)

The officers treat everyone with dignity. (9)

The officers treat everyone equally.

The officers respect people's rights. (11) 
The officers follow through on the decisions and promises they make.

The officers always act within the law.

The officers take account of the needs and concerns of people they deal with. (14)

The officers sincerely try to help people with their problems. (15)

The officers clearly explain the reasons for their actions. (16)

The officers try to find the best solutions for people's problems. (17)

The officers provide opportunity for unfair decisions to be corrected. (18)

The officers use rules and procedures that are fair to everyone. (19)

The officers respond promptly to calls about crimes (for example, robbery, assault). (20)

The officers are always ready to provide satisfactory assistance to victims 
CONFIDENCE IN LAW ENFORCEMENT

of crime. (21)

The officers are always able to provide the assistance the public needs from them.

The officers are doing well in controlling violent crime (for example, armed robbery). (23)

The officers are doing a good job overall in my neighborhood. (24) 
Q6 Rate whether you agree or disagree with each of the following statements about the community in which you live.

\begin{tabular}{|c|c|c|c|}
\hline & Agree (3) & $\begin{array}{l}\text { Neither Agree nor } \\
\text { Disagree (2) }\end{array}$ & Disagree (1) \\
\hline $\begin{array}{l}\text { Crime levels in my } \\
\text { neighborhood have } \\
\text { changed for the } \\
\text { better in the last } \\
\text { year. (1) }\end{array}$ & & & \\
\hline $\begin{array}{l}\text { There are not many } \\
\text { instances of crime in } \\
\text { my neighborhood. } \\
\text { (2) }\end{array}$ & & & \\
\hline $\begin{array}{l}\text { I trust the law } \\
\text { enforcement officers } \\
\text { who serve my } \\
\text { community. (3) }\end{array}$ & & & \\
\hline $\begin{array}{c}\text { I feel safe walking in } \\
\text { my neighborhood at } \\
\text { night. (4) }\end{array}$ & & & \\
\hline $\begin{array}{l}\text { My neighborhood is } \\
\text { a good place to live } \\
\text { in terms of personal } \\
\text { security. (5) }\end{array}$ & & & \\
\hline $\begin{array}{l}\text { When law } \\
\text { enforcement officers } \\
\text { in my community } \\
\text { stop people they } \\
\text { usually handle the } \\
\text { situation well. (6) }\end{array}$ & & & \\
\hline $\begin{array}{l}\text { I am satisfied with } \\
\text { the law enforcement } \\
\text { officers serving my } \\
\text { community (7) }\end{array}$ & & & \\
\hline
\end{tabular}


Q7 Have you had professional contact with a law enforcement officer in the past twelve months (do not include social contact)?

\section{Yes (1)}

No (2)

Choose not to answer (3)

Q8 Considering only the most memorable (non-social) contact you had with law enforcement in the past twelve months, please select one of the following.

It was a positive contact (3)

It was a negative contact (1)

It was a neutral contact - the contact with neither positive nor negative (2)

Q11 Here is your ID: MEKA2334

Copy the ID above and paste it into the box below.

Once you have entered either your ID or your MTurk ID into the box below, press enter to submit your survey responses. 


\section{CONFIDENCE IN LAW ENFORCEMENT}

\section{Tables}

Table 1. Key Components of the Racial Confidence Gap (percentages of respondents) ................................................................................ 17

Table 2. The Racial Dimensions of Civilian Trust / Confidence (in percent) 18

Table 3: Jurisdiction-Level Citizen Satisfaction Surveys - A Subset ...........26

Table 4. Mapping the Survey Questions/Items and a priori Factors

Table 5. Participant Characteristics ...............................................................5

Table 6. Ordinal Logistic Regression Model Runs and Key Statistics .........75

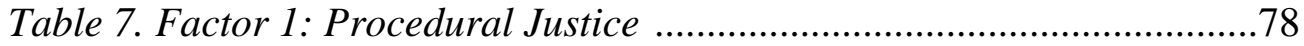

Table 8. Factor 2: Police Effectiveness ...................................................78 


\section{CONFIDENCE IN LAW ENFORCEMENT}

\section{Figures}

Figure 1. The Principles of Civilian Trust/Confidence in Local Law Enforcement

Figure 2. The Benefits of Civilian Trust/Confidence in Local

Law Enforcement

Figure 3. Racial Mirror Index-African American ("RMI-AA")

Figure 4: RMI-AA for All Study Agencies-Circle Diameter

Reflects RMI-AA

Figure 5: Full-time Sworn Officers per Agency in Study

Figure 6: Civilian Population Served per Agency in Study

Figure 7: Racial Mirror Index-African-American for Cities in Study

Figure 8: RMI-AA for Study Agencies - Agencies with RMI-AA $<51$

Figure 9: RMI-AA for Study Agencies - Agencies with RMI-AA = 51-75 ...56

Figure 10: RMI-AA for Study Agencies - Agencies with

$R M I-A A=76-100$

Figure 11: RMI-AA for Study Agencies - Agencies with RMI-AA > 100 .....57

Figure 12: Scree Plot of Unrotated Factor Analysis Assessing Kaiser Criterion

Figure 13. Factor Loadings on Two-Factor Solution - Unrotated

Figure 14. Factor Interpretation for Unrotated Model

Figure 15. Promax-rotated Factor Matrix without Neighborhood Context Variables

Figure 16. Parametric Correlations Among Confidence, Trust, and Satisfaction

Figure 17. Nonparametric Correlations Among Confidence, Trust, and Satisfaction

Figure 18. Histogram for RMI by Low Confidence

(on a common $x$-scale) 


\section{CONFIDENCE IN LAW ENFORCEMENT}

Figure 19. Histogram for RMI by Neutral Confidence

(common $x$-scale)

Figure 20. Histogram for RMI by High Confidence

(on a common $x$-scale)

Figure 21. Histogram for RMI by Low Trust

(on a common $x$-scale)

Figure 22. Histogram for RMI by Neutral Trust

(on a common $x$-scale)

Figure 23. Histogram for RMI by High Confidence

(on a common $x$-scale)

Figure 24. Histogram for RMI by Low Satisfaction

(on a common $x$-scale)

Figure 25. Histogram for RMI by Neutral Satisfaction

(common $x$-scale)

Figure 26. Histogram for RMI by High Satisfaction

(on a common $x$-scale) 